Historic, Archive Document

Do not assume content reflects current scientific knowledge, policies, or practices. 


$$
\text { . }
$$




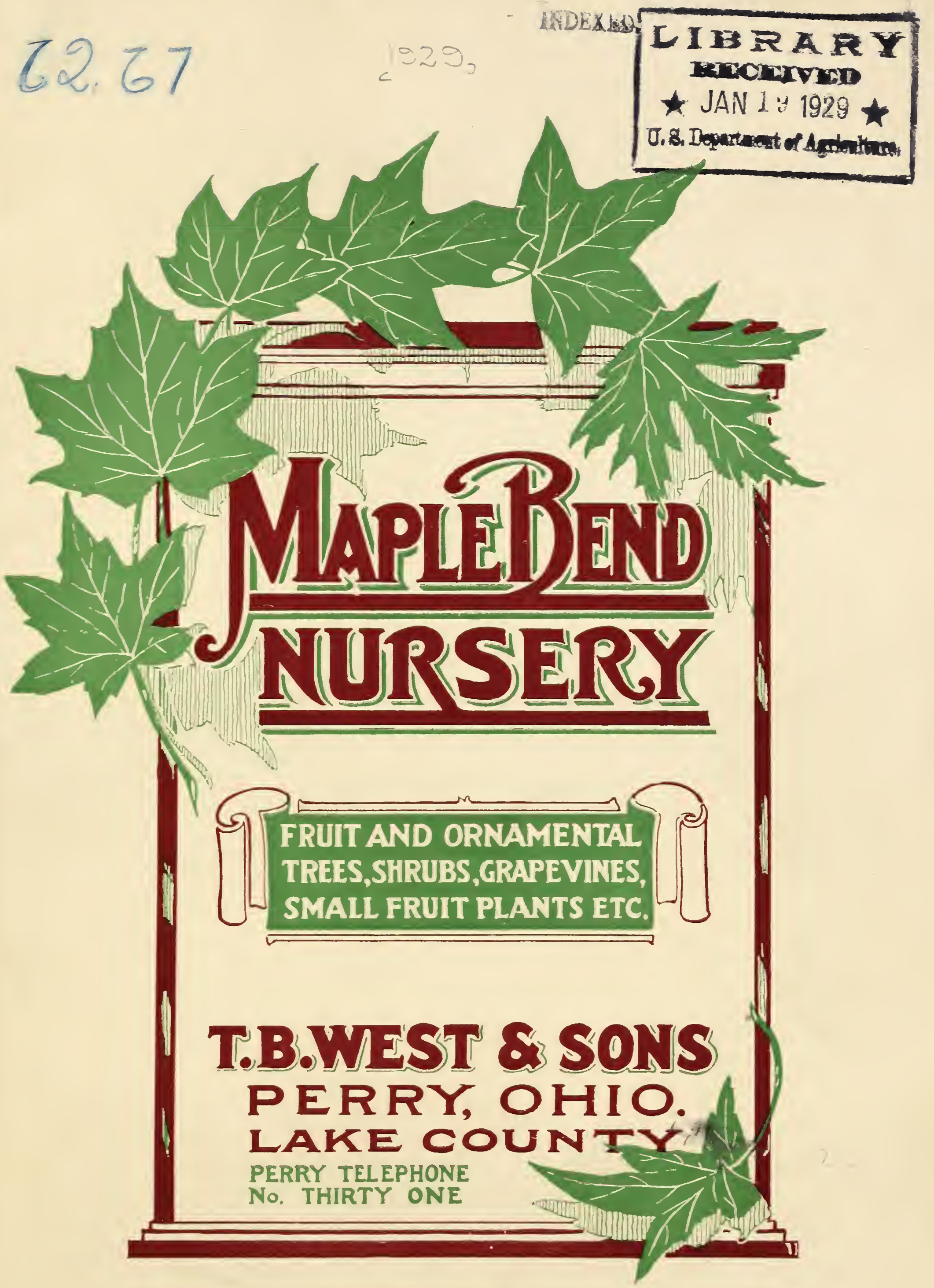

\section{N. Shoemaker}




\section{CONDITION OF SALE}

Stock will be supplied at the prices named in this list as follows: On orders of $\$ 25.00$ and upwards everything may be selected at the 100 rate regardless of quantity taken; get your neighbors to club with you and take advantage of the above rates. In all cases 5 will be furnished at the 10 rate, and 50 at the 100 rate.

Terms: Cash with order unless otherwise agreed upon. If goods are desired C. O. D. the order must be accompanied by one-third of the amount to guarantee acceptance.

Remittances should be made by P. O. Money Order, Registered Letter, Express Money Order, or New York Draft.

WTe guarantee all stock to be up to size arnd grade specified in list, to be in good condition and well packed when it leaves our grounds; this guarantee holds good only when prompt notification on arrival of stock is sent us, stating plainly any errors or cause for complaint. All claims for errors must be made within ten days after receipt of goods.

We cau make direct shipment on the New York Central or Nickel Plate Railroads. American Express, and some items by Parcel Post; customers paving transportation charges. All heavy trees in large quantities should be sent by freight, as the charges are so much less, and our perfect packing admits of a long journey without injury to trees. Always give full and explicit directions for shipping, as our responsibility ends on delivery of trees in good condition to the carriers. If goods suffer through delay in transit, claim should be made on transportation company.

While we exercise the greatest diligence and care to have all our trees, etc, true to label, and hold ourselves in readiness on proper proof to replace all trees, etc., that may prove untrue to label free of charge or refund the amount paid, it is mutually understood and agreed to between the purchaser and ourselves, that the guarantee of genuineness shall in no case make us liable for any sum greater than that originally received for said trees, etc., that may prove untrue.

We will be pleased to quote prices to anyone desiring different sizes of stock, or larger quantities than offered herein. In sending list state definitely the number of each variety and size wanted.

In filling orders from this list we resere the right, in case we are out of a variety, to substitute another of equal merit when it can be done (always labeling with the correct name), unless the party ordering says, "no substituting," in which case we will fill the ordel, so far as we can, and return the balance.

\section{DISTANCES FOR PLANTING}

Standard Apples_...................................... Standard Pears and Strong Growing Cherries_..............20 feet apart each way Duke and Morello Cherries_................................... 20 feet apart each way Standard Plums, Peaches, Apricots, Nectarines_.........16 to 18 feet apart each way Dwarf Pears ..................................................... to 12 feet apart each way Dwarf Apples...................................................... to 12 feet apart each way Quinces _.......................................................... 10 to 12 feet apart each way Grapes ................................................ 8 feet apart, 5 feet in rows Currants and Gooseberries _...................................... feet apart Raspberies and Blackberries ............................ 3 to 4 by 5 to 7 feet

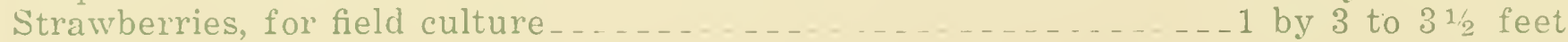

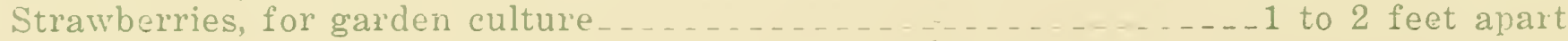

\section{NUMBER OF TREES ON AN ACRE.}

3 feet apart each way $\ldots \ldots \ldots+\ldots 40$

4 feet apart each way $\ldots \ldots \ldots . .2725$

5 feet apart each way

6 feet apart each wà

8 feet apart each way........ 680

10 feet apart each way........ 435

12 feet apart each way $\ldots \ldots \ldots+\ldots 300$

15 feet apart each way _....... 205

18 feet apart each way........ 135

20 feet apart each way ......... 110

25 feet apart each way $\ldots \ldots \ldots+\ldots$

30 feet apart each way ....... 50

RULE-Muitiply the distance in feet between the rows by the distance the plants are apart in the rows, and the product will be the number of square teet 1or eich plant or hill, which if divided into the number of square feet in an acre $(43,560)$ will give the number of plants or trees to the acre. 


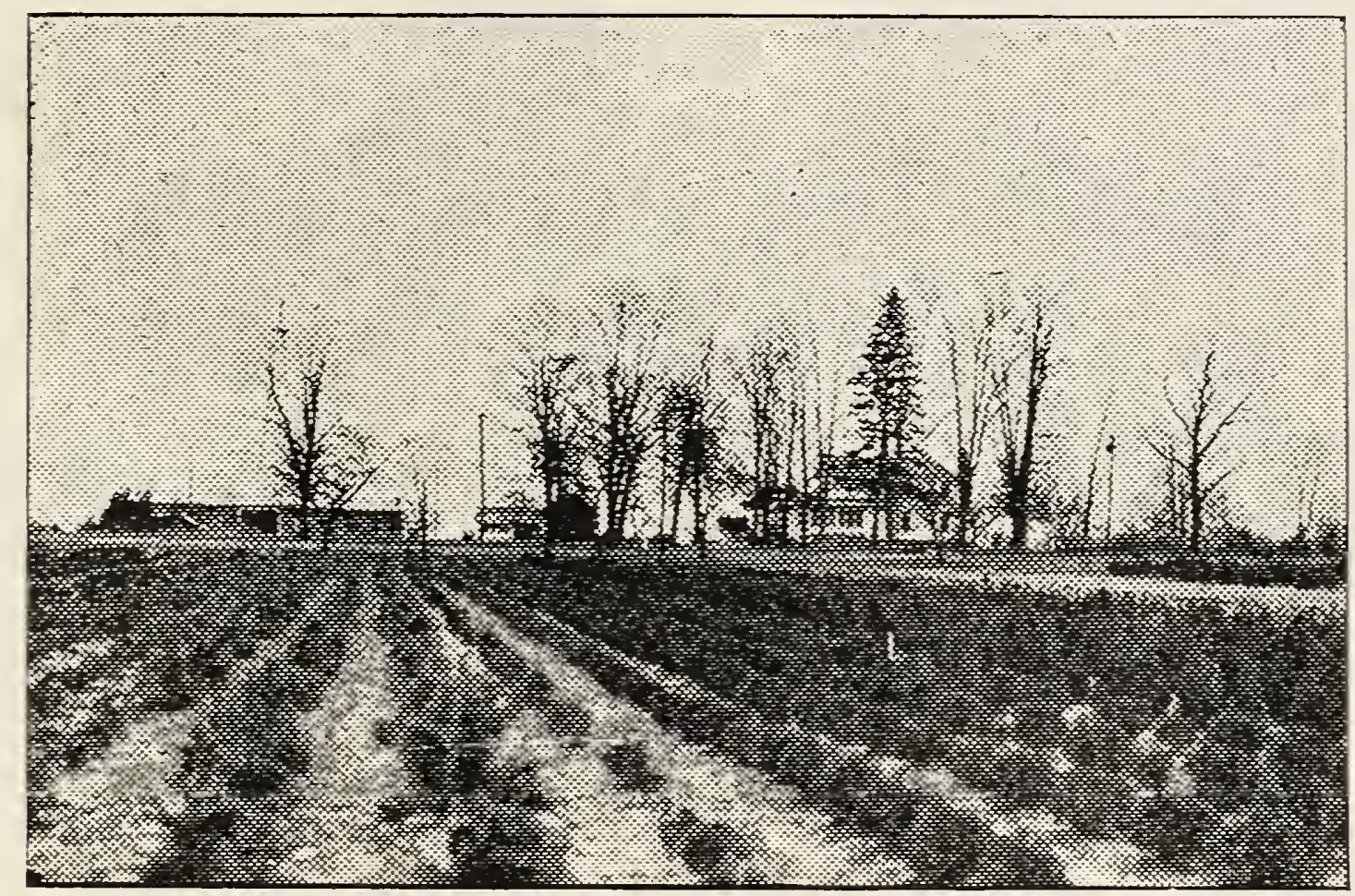

\section{A WORD WITH YOU}

$\mathbf{O}$

NE of the pleasures of doing business is the greetings and friendships that grow up from its associations. The same spirit of friendship and co-operation abounds in our business done by mail, as with those whom we meet face to face because we all respond to the same good intention and service through whatever medium we meet, and again offer kindly greetings to old customers, and extend the hope that we may prove our merit to the newcomer by the quality of our stock and the fidelity with which we look after their interest in the details that fall to our part of the transaction.

Giving our personal attention to the propagating and packing of our Nursery Stock, we feel assured that our customers will get what we understand that they want, and that it will be delivered in the best possible condition, and found exactly as represented, as nearly as painstaking care and attention, with a determination to please, can make it. prices.

Those wanting a large amount of stock should send list of what they want for special

We aim to raise the best stock, graded to the highest standard, strongly grown, well rooted and thrifty.

We think a satisfied customer is the best advertising medium.

We do not believe in the policy of replacing stock which dies after transplanting from natural or other causes. Our experience in the past has proven that the practice of replacing free, has a tendency to encourage carelessness on the part of the planter and also to marring to some extent the friendly relationship that ought to exist between the nurseryman and the planter. The most scrupulous care is exercised in the handling of trees from the time of digging until packed for shipment. No chance for injury to stock before shipment is possible under our system. With proper care but few of our trees fail to grow.

Our northern location is worthy of special mention. One of the great advantages so liberally bestowed upon us by nature is a lovely, cool and healthy climate; an atmosphere purified and tempered by the balmy breezes of Lake Erie, where fungus diseases are rarely found. The soil is rich loam of wonderful fertility, very rich in nitrogen, and underlaid with a porous clay subsoil, eminently adapted to the production of hardy trees, etc. These facts no doubt to some extent account for the uncommon vigor of our trees and plants when afterwards transplanted. Our stock always ripens up thoroughly in the fall and goes into winter without danger of being injured by severe frost. A comparison will prove that our stock has not the willowy and watery soft growth of Southern or Western grown stock, which no doubt accounts in a measure for the large and increasing demand for our Northern grown stock. The wood is firm and hard, the bodies strong, while the roots have strong forcing power. Such trees cannot fail to make good and profitable orchards. 


\section{APPLES}

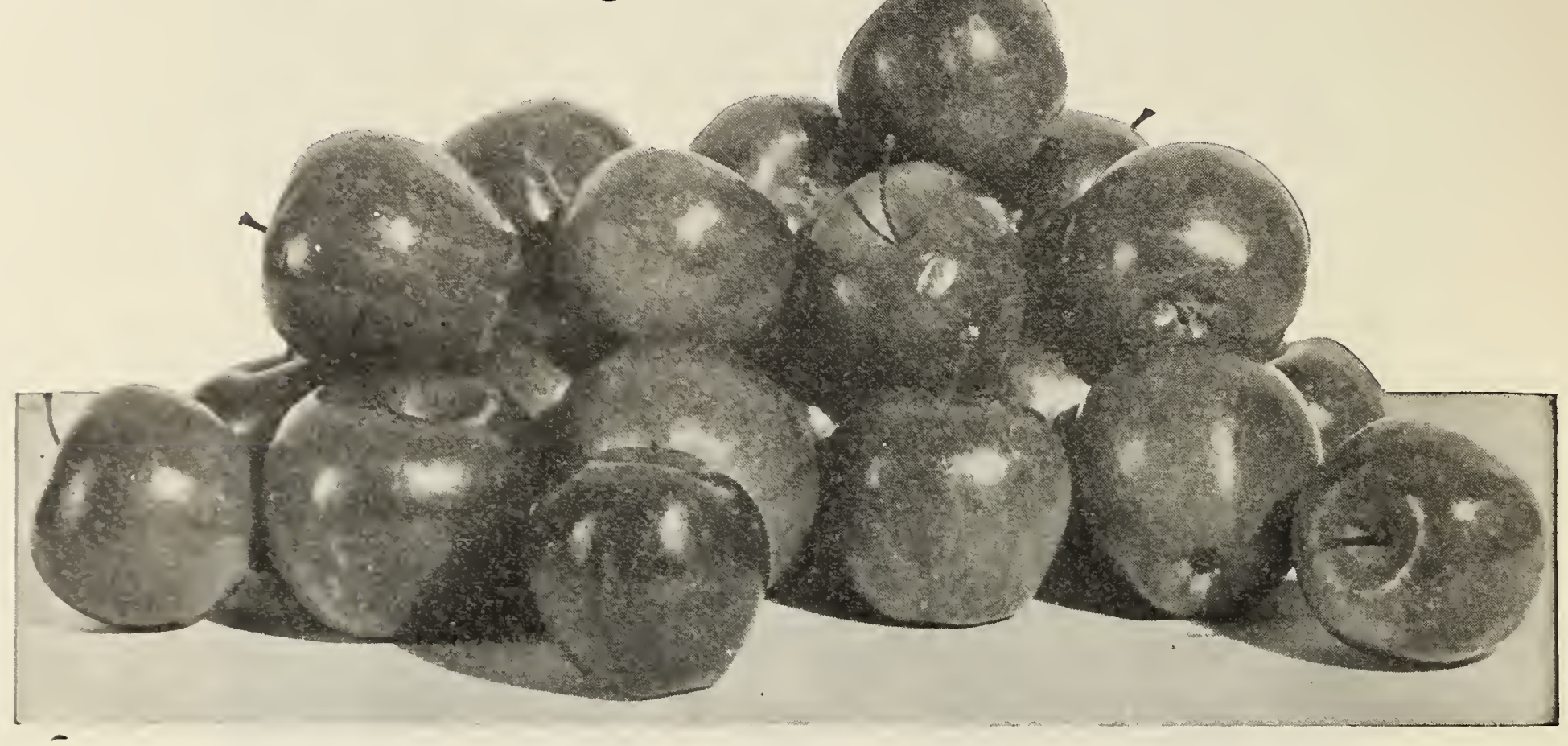

Delicious

$\mathbf{E}$ VERY farm should have its apple orchard. We have often been asked, how long before trees will come into bearing after being planted. Of course conditions and the manner of treatment of the trees after planting have a great deal to do with this; but under ordinarily favorable circumstances the following table may be a guide to help you. Some varieties bear much sooner than others. The following varieties will come into bearing from 3 to 5 years from planting: Yellow Transparent, Oldenberg, Rome Beauty, Grimes, Wagener, Wealthy, McIntosh, Maiden Blush, Stayman, Gravenstein, Banana, Delicious, Gano, Northwestern, Stark, Jonathan, and York Imperial. These should begin to bear in 5 to 8 years from planting: Early Harvest, Red Astrachan, Sweet Bough, Golden Sweet, Baldwin, Hubbardston, Northern Spy, and R. I. Greening. Of course this does not complete the entire list of varieties we offer, but it will be a guide to those wishing to plant.

Apple trees should be planted from 25 to 40 feet apart, according to local conditions, soil, and varieties. They will do well on nearly any well drained soil.,

When planting an orchard it should be borne in mind that the planter is making a long time investment.

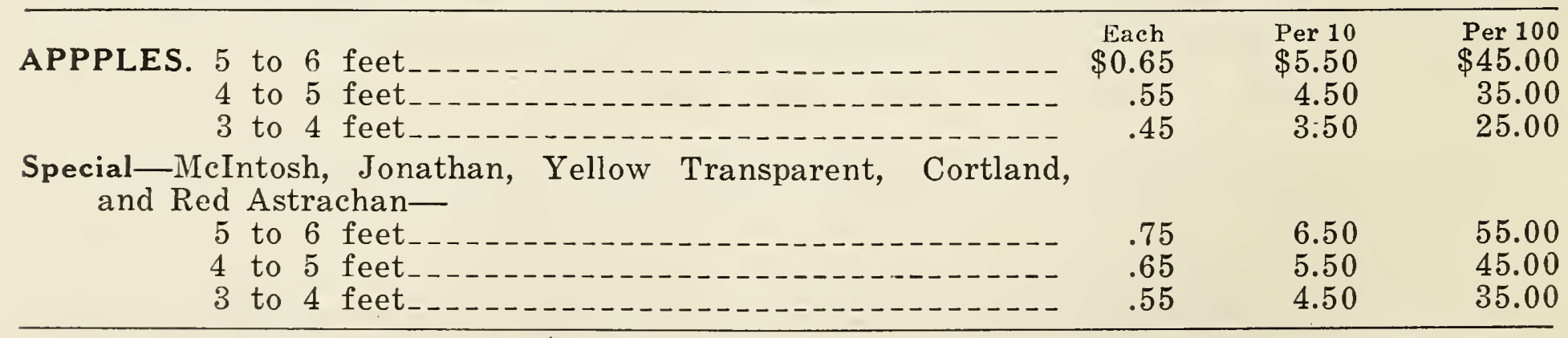

\section{SUMMER VARIETIES}

Early Harvest. Fruit is medium size to large; the skin tender, very smooth, clear pale waxen yellow. Sub-acid. July.

Golden Sweet. Rather large. Pale yellow. One of the best sweet apples. August.

Liveland Raspberry. Fruit good sized, clear, waxen white, striped crimson; flesh snow white. Blooms late, is blight resistant, bears early, makes a good filler.

Red Astrachan. Deep crimson sometimes striped with yellowish green; medium to large in size, tender, tart. For nearby markets one of the most profitable apples. Last of July to the middle of August.

Sweet Bough. Large yellow, sugar sweet. Hardy. August.

Yellow Transparent. One of the best known summer apples. Often bears the second year after planting. Pale yellow, pleasantly acid, tender and good.

\section{FALL VARIETIES}

Chenango Strawberry. Large beautiful fruit, yellowish-white striped with red, excellent quality, early and regular bearer. September to November.

Fall Pippin. Large beautiful yellow, rich and tender. September to December.

Gravenstein. Greenish yellow striped with red. Highly flavored. Valuable for market and cooking. September to November.

Lowell. Fruit rather large; clear yellow with waxy surface. Flesh a litttle coarse, very juicy; slightly sub-acid, and desirable for either dessert or culinary uses. Season extends from late August to October. Tree hardy and strong grower. 
Maiden Blush. Creamy yellow flushed with red. September and October.

Munson Sweet. Pale yellow, often somewhat blushed. October and November.

Oldenberg. (Duchess of Oldenburg.) Yellow striped and mottled with red. Thrifty and does well in nearly all sections, comes into bearing the third year after planting. The trees are naturally dwarf growers and make fine fillers. Late August and September.

Rambo. A fine well known red variety. Late fall.

\section{WINTER VARIETIES}

Baldwin. One of the best known market varieties of the northern states. In the territory north of Columbus, Ohio, through Pennsylvania, New York, Michigan, Northern Indiana, and the New England states, it is the leading market variety. It is one of the most reliable of the old sorts. Large, deep red, crisp, juicy flesh, good flavor.

Banana. A very early and annual bearer. Beautiful golden yellow. One of the most successful of the winter varieties, and should be included in every collection. Flesh sweet, tender and juicy.

Delicious. Large, oblong, brilliant dark red, with fine-grained, juicy crisp and melting flesh. Hardy, and an early and productive bearer. One of the best new varieties, which has been successfully grown in most every section of the country.

Ensee. Seedling from the Rome Beauty, Said to be of superior quality but retaining all the other good features of that splendid old variety, which it somewhat resembles.

Fallawater. Large, with smooth skin of a yellowish green, with a dull red cheek. Flesh white, crisp and juicy. Tree a fast grower and productive. Sometimes known as the Tulpehocken.

Fameuse. (Snow.) Medium size, deep crimson, snowy white, tender, melting flesh of fine flavor.

Gano. Sometimes called the Black Ben Davis. A great improvement over the Ben Davis which it somewhat resembles, but is of much finer quality. Dark red color, flesh crisp. Juicy and of fine flavor.

Golden Russet. Fruit medium, golden russet, with bronze cheek. Tree hardy and a reliable cropper. December to April.

Grimes. Good size, yellow, slightly russeted, juicy, rich, good keeper retaining its crispness and flavor. One of the best winter apples.

Hubbardston. Large, handsome, yellow, overlaid with red; tender flesh, delicious flavor. Hardy and productive.

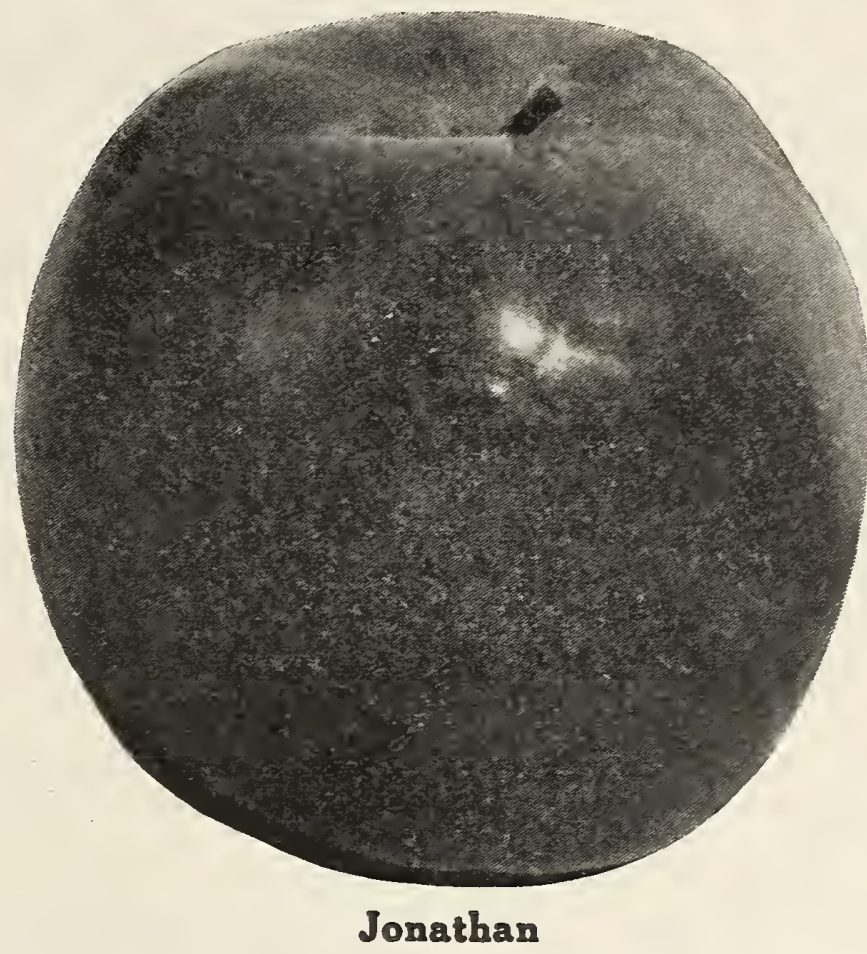

Jonathan. Medium size, pale yellow heavily overlaid with red; flesh whitish, tender, crisp, juicy, slightly sub-acid. A fine keeper.

King. Very large, red, fair quality, very productive, flesh is slightly coarse but tender and vinous.

McIntosh. Good size, yellow washed and deeply blushed with bright red; flesh white, tender, crisp, juicy, slightly sub-acid becoming mild and nearly sweet when ripe.

Northern Spy. One of the oldest and best known varieties. Large, pale yellow ground nearly covered with bright red; effect bright red or striped red, flesh yellowish, tender, crisp, juicy and sub-acid. Tree hardy and strong growing.

Northwestern. Medium to large; clear pale yellow or greenish yellow; flesh yellowish, mild sub-acid, juicy. A good hardy variety.

Pumpkin Sweet. Fruit large to very large, marbled with light and dark green; streaked with whitish scarf-skin. Tree strong grower and long lived. October to January.

Cortland. New variety. A cross between the McIntosh and Ben Davis, having the good qualities of the $\mathrm{Mc}$ Intosh, being later in season, of high quality and good color and keeping well to the last of winter. New York State growers are very enthusiastic over it and it is recommended very highly by the experimental station of New York State.

Rome Beauty. Has been the best money maker of any apple through southern Ohio, Pennsylvania, New York and West Virginia. Medium to large size; golden yellow ground, mottled and overlaid with red. Flesh nearly white, firm, crisp, juicy, mild, sub-acid. 
R. I. Greening. Large, greenish yellow, fine quality, the best for culinary purposes. The tree bears regularly and profusely.

Stark. Large, greenish yellow, striped with red. Flesh is yellow, moderately juicy, mild, sub-acid. Vigorous.

Stayman. Of high quality, annual and prolific bearer, medium to large size, red and yellow ground. One of the finest apples for fancy trade when properly grown.

Sutton. A desirable market variety. Medium to large, bright red nearly overspreading the yellow ground; flesh crisp, tender, mild sub-acid.

Tolman. Medium size; pale yellow slightly tinged with red, firm, rich and sweet; excellent for baking.

Twenty-Ounce. Very large and handsome, washed, mottled and splashed with bright red; flesh coarse, juicy and sub-acid.

Wagener. One of the best apples for this northern section. Medium to large, smooth, glossy, pinkish-red striped with bright carmine, on a pale yellow ground; crisp, tender, juicy, sub-acid; very good.
Wealthy. Large, yellow, blushed and striped with red; effect very bright red. Fresh, crisp, tender, very juicy and very good. Early, regular and abundant bearer.

Wolf River. Large, pale yellow or greenish, mottled and splashed with deep red. Flesh firm, tender, juicy and sub-acid.

York Imperial. A very important commercial variety. Does well everywhere. Medium size, yellow or green blushed with light red or pinkish red. Flesh firm, crisp, mild subacid.

\section{CRAB APPLES}

Hyslop. Large deep red fruit, that hangs thickly in clusters.

Transcendent. Large, golden yellow striped with red; excellent for culinary use; very productive.

Whitney. Large, smooth, glossy green, heavily striped with carmine. Tree hardy, vigorous and heavy bearer.

\section{A FEW GOOD WORDS FROM SOME OF OUR CUSTOMERS THIS IS ALL THE SPACE WE HAVE}

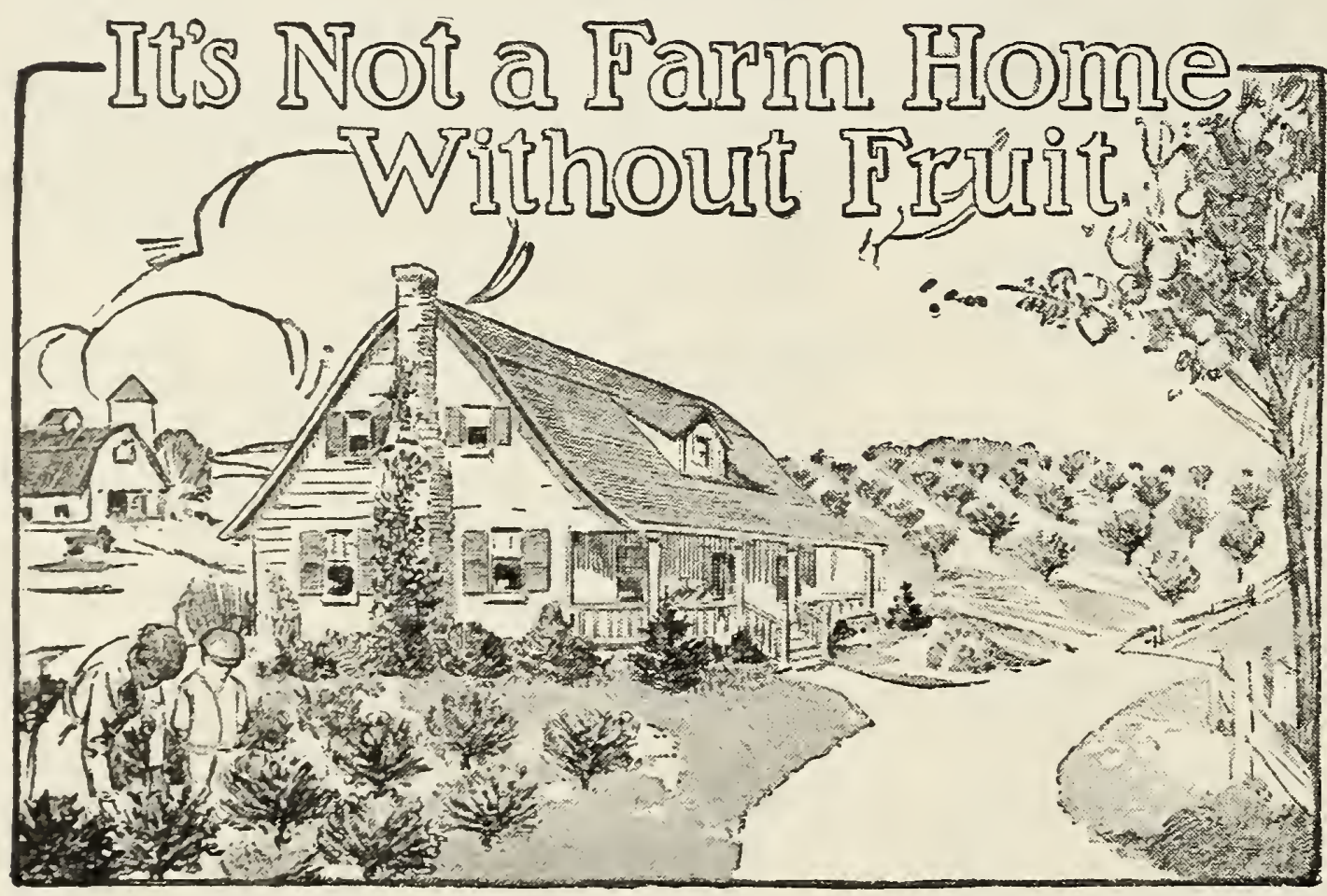

Washtenaw County, Mich. Oct. $20,1926$.

T. B. West \& Sons,

Perry, Ohio.

Dear Sirs:

Enclosed please find Money Or. der for the Concord Grapes. They were the best roots I have ever seen and are doing nicely.

From the first ones I planted, I got my first crop this year. I had the best Grapes on the Detroit and Ann Arbor markets and got a good price for them even though there were so many.

Yours very truly, Newton Beard.
Delaware County, Ohio. June 10,1926

Messrs. T. B. West \& Sons, Perry, Ohio.

Dear Sirs :

Enclosed find my check to cover invoice of April 16th. Allow me to thank you for the quality of this order.

When it comes time to issue and mail out your catalogue for the season of 1927, kindly have me on

I fully intend in the coming spring to renew my order which I was obliged to cancel this spring. Very traly sours, D. M. Cupp. that mailing list.
Lucas County, Ohio, April 15, 1925. T. B. West \& Sons, Perry, Ohio. Gentlemen :

Enclosed find check for the Apple Trees. They came through all right and all the trees were very satisfact. ory.

Respectully,

J. W. Farnsworth.

T. B. West \& Sons,

Perry, Ohio.

Gentlemen :

The Strawberry Plants came all right and in fine condition. Thank you for replacing the 150 . You have always been fair and square in dealing with us.

Wishing you success in the future, I am Yours truly,

Mrs. Hattie Butman.

Lorain County, Ohio. Feb. 18, 1926

T. B. West \& Sons,

Perry, Ohio.

Gentlemen :

I am sending you herewith my order for Fruit Trees and Plants. Kindly look it over and advise me whether or not you can fill it as specified as to varieties.

It has been several years since I have bought any Nursery Stock at all, but have always been well satisfied with yours in the past.

Respectfully yours,

C. W. Nieding 


\section{CHERRY TREES}

C HERRIES are one of the most profitable ventures there is, as they require but little care, are thrifty, and bear large crops annually. They are easily picked and always in good demand. Also they make a very attractive as well as profitable road-side tree, in place of the ordinary shade tree. Cherry trees do best on a warm, gravelly soil, well-drained, and should be planted from 16 to 20 feet apart.

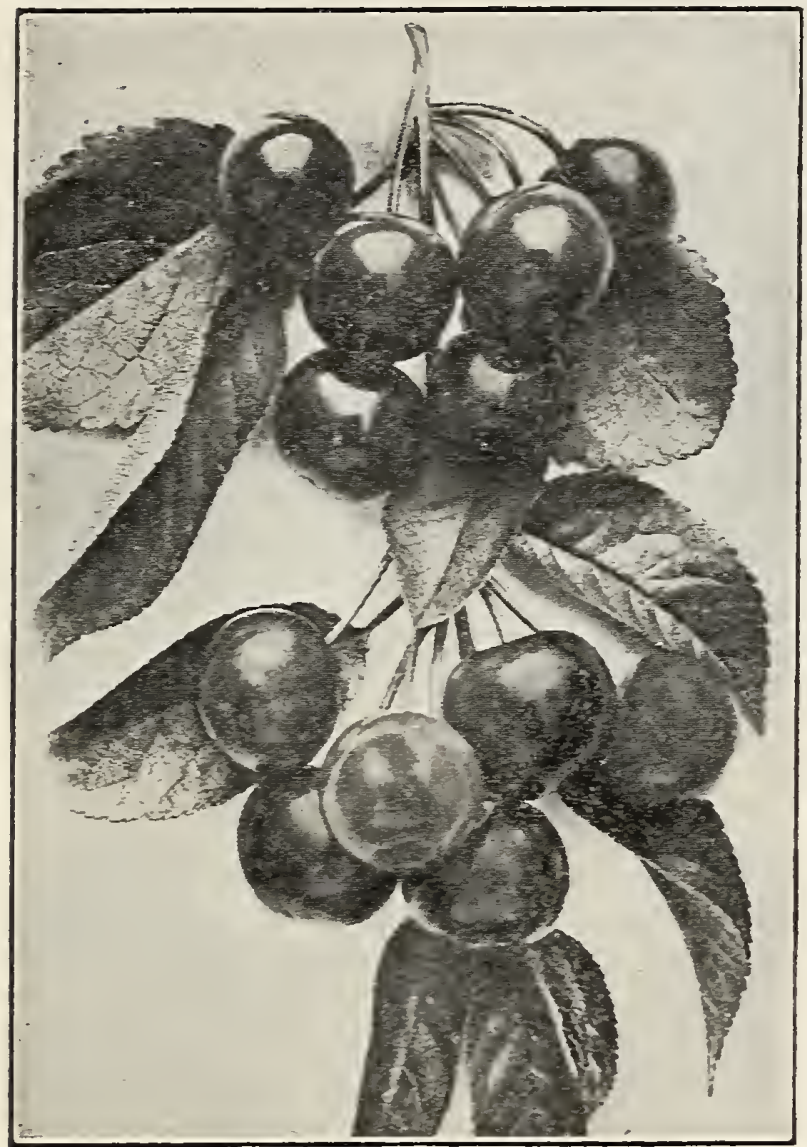

Montmorency
Sweet Varieties

Each Per 10 Per 100

CHERRIES: 5 to 6 feet.-- $\$ 1.25$

4 to 5 feet... 1.00

$\$ 10.00$

8.00

\section{Sour Varieties}

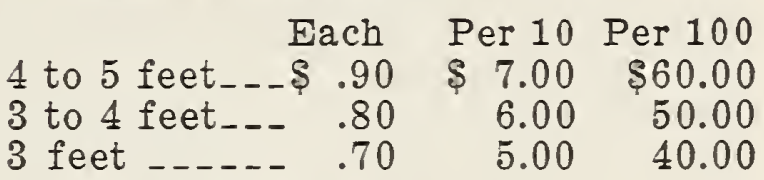

\section{Sweet Varieties}

Bing. Very large, very dark red, almost black flesh, purplish red, firm, sweet, very good quality. Mid-season to later.

Lambert. Very large, dark red, changing to reddish black; flesh dark red, meaty, firm and sweet, good quality. Hardy and productive. Mid-seasson.

Napoleon. Large, bright red over yellow background; fiesh whiteish, with yellow tinge, tender, meaty, crisp and sweet. Mid-season.

Schmidt. Purplish black; flesh purplish red, dark colored, juicy, crisp, firm, sweet, good quality. Large. Mid-season.

Spanish. Bright amber yellow with red blush; flesh whiteish, tender, crisp, sweet, very good. Mid-season.

Tartarian. Large, purplish black; flesh mild, sweet, very good quality. Late June and early July.

Windsor. Fine large liver-colored cherry. Flesh firm and good. One of the best sweet cherries.

Wood. Large, round, heart-shaped, yellow, mottled with red, flesh sweet, juicy and d e li c i o us. Tre e healthy, vigorous and a great bearer. June.

\section{Sour Varieties}

Dyehouse. Very early medium size, bright red, juicy, with slightly tart flavor. Excellentfor canning. June.

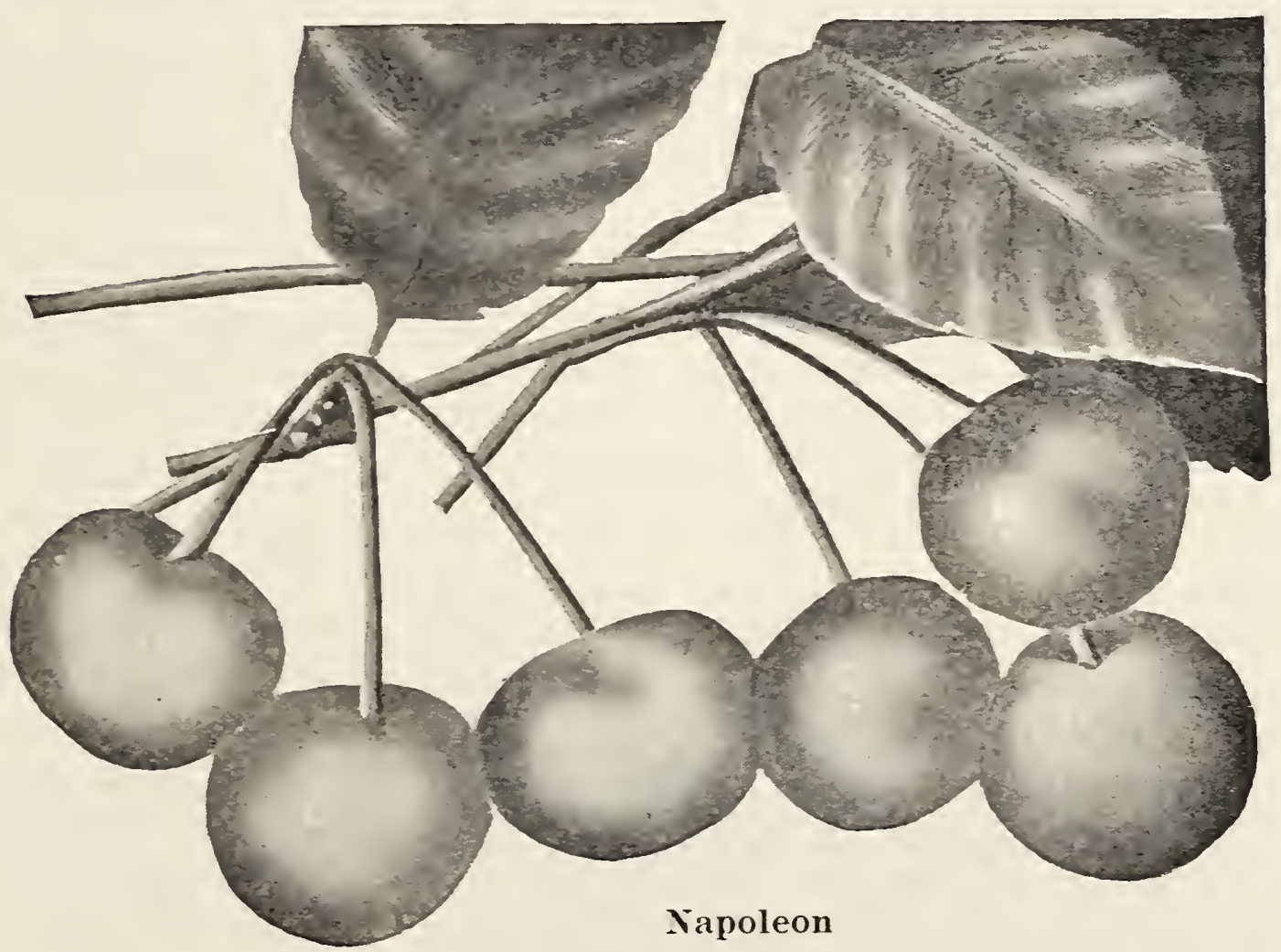

Early Richmond. Very productive and old variety; fruit dark red, medium size, tender and juicy. One of the most valuable of the acid cherries and is unsurpassed for cooking purposes. Tree slender grower, productive. June.

May Duke. Large, dark red, juicy, rich. Late June.

Montmorency. Ripens about ten days after the Early Richmond. Large, round, handsome red; flesh fine flavored, sub-acid, rich. Recommended for kitchen and nearby market. Tree a good grower, hardy, productive. Late June.

Morello. Large, dark red, tender and juicy; acid rich. A late sort. 


\section{PEACH TREES}

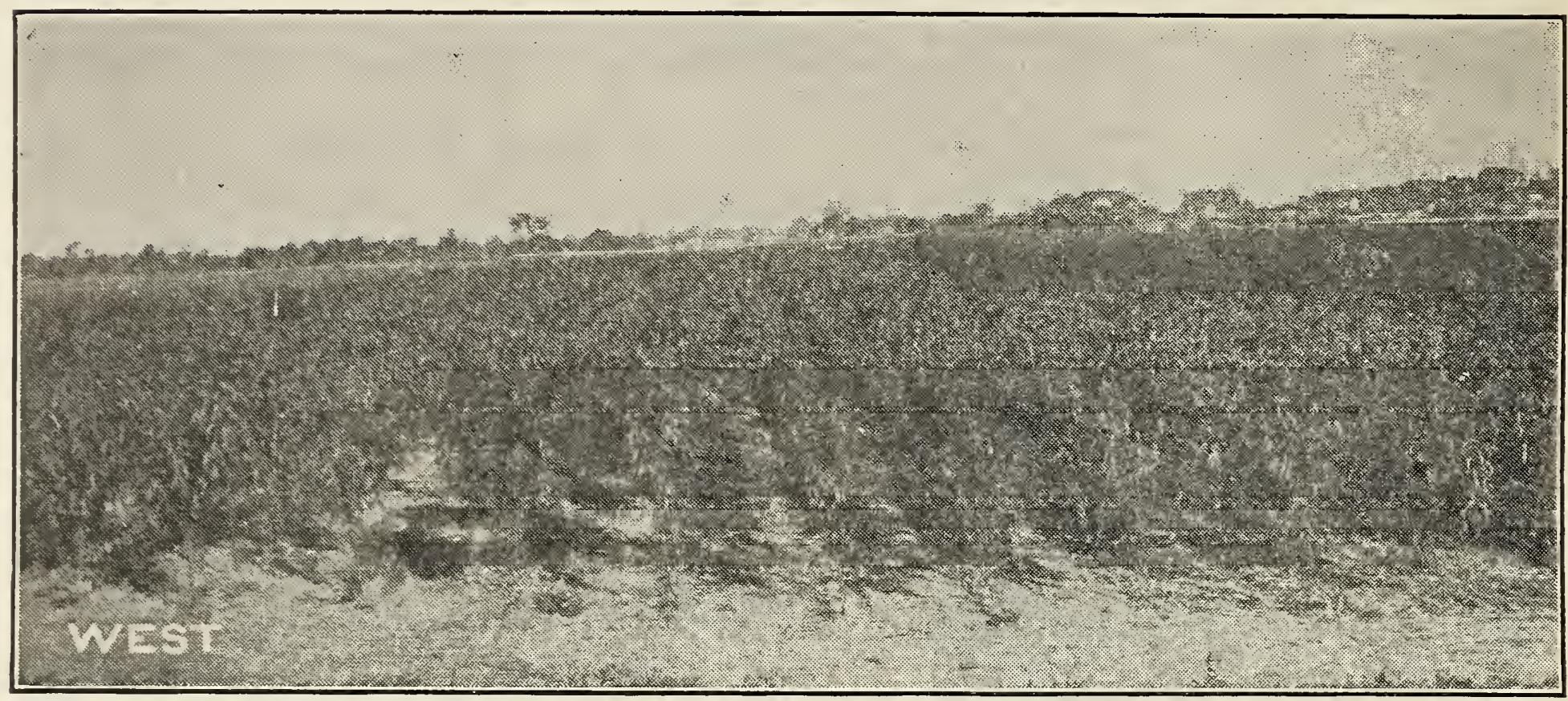

A Block of 200,000 Peach Trees

$\mathbf{P}$

EACH TREES grown in northern Ohio are considered by Peach growers and Peach orchardists as the very best that are grown anywhere in the country. The soil and climate conditions are ideal for the growing of these trees. We grow hundreds of thousands of them every year, and many of the best orchards in the largest fruit growing districts of the northern states are from our trees. Peach trees are one of our specialties.

Peach trees need a warm, well drained soil, and should be planted 16 to 18 feet apart, and thoroughly cultivated and pruned.

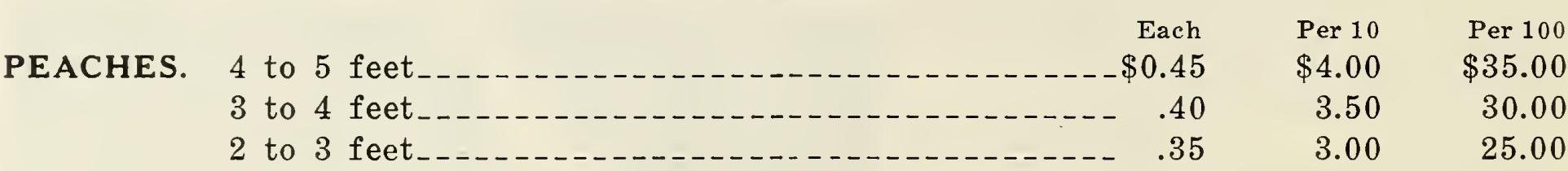

Banner. Large deep yellow with crimson cheek; flesh yellow and of fine quality, rich and firm. Good shipper and keeper. Tree hardy, vigorous and very productive. Last of September and first of October.

Beer Smock. Large, yellow, flesh red at stone, good quality and very productive. The best late market variety. Last of September and first part of October.

Belle of Georgia. Very large; skin is white with red cheek; flesh white, firm, good flavor. August.

Carmén. Large, pale yellow with deep blush. Flesh tender, white, juicy, fine flavor. Hardy. First of August.

Chair's. Very large, deep yellow, with red cheek. Flesh firm, yellow, rich, good quality. Ripens five days earlier than the Smock.
Champion. Very large, white with red cheek; flesh sweet, rich and juicy. One of the very best early peaches. August.

Crawford's Early. Very large yellow peach; good quality and very productive. Late August.

Crawford's Late. Similar to Crawford's Early but a month later in ripening. Late September.

Crosby. Medium size, bright yellow streaked with red; flesh yellow and of good flavor. Tree hardy and productive. September.

Elberta. The leading market variety. Fruit large, handsome, bright yellow overspread with crimson; flesh yellow, firm, juicy, good quality. Late August and early September. 
Early Elberta. Ripens about a week earlier than the Elberta; otherwise the same, or a trifle better quality.

Engle. A very fine late market sort. Resembles the Crawford's Late but is more productive. Sept.

Fitzgerald. Large bright yellow suffused with red; flesh vellow, best quality. Very hardy, heavy cropper. Late August.

Greensboro. The largest and the most beautifully colored of the early varieties. Flesh white, juicy and good. July.

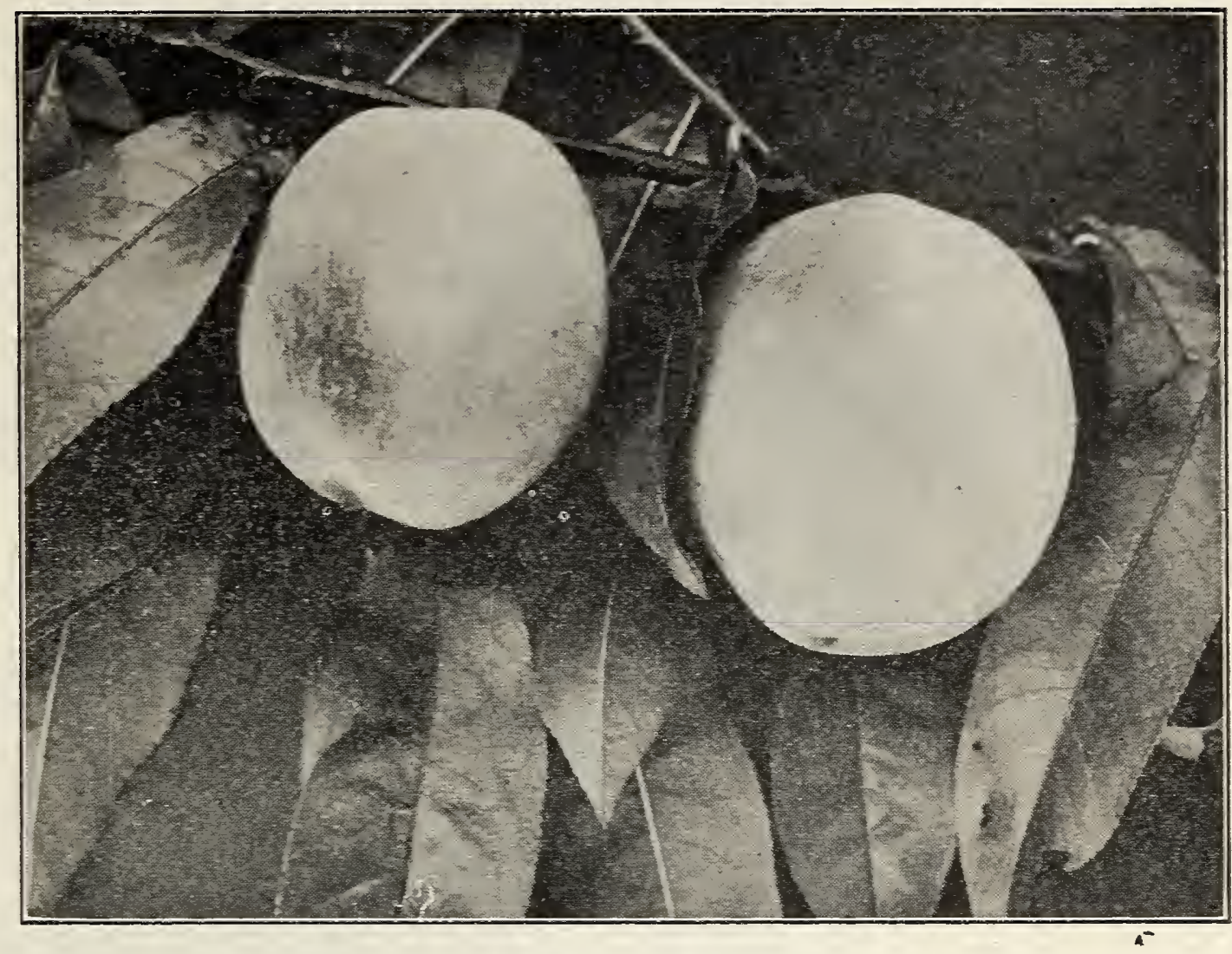

Hale. A large deep golden yellow peach, overlaid with bright carmine. Smooth; flesh firm, fine grained and a perfect freestone. Last of August.

Heath Cling. Large, creamy white, with faint blush, fine quality and a good keeper. Valuable for preserving and canning. October.

Kalamazoo. Large, golden yellow, crimson cheek, fine flavor and small pit. Tree strong, hardy and regular bearer. September.

Lemon Free. Very large lemon-shaped, pale yellow, excellent quality, very productive. One of the most valuable sorts. Very good for canning. Late September.

Niagara. A very large yellow peach of good quality and productiveness. Ripens just after the Elberta.

Prolific. Large, yellow peach of good quality Hardy and productive. September.

Rochester. Large, hardy, yellow tinged with carmine. Mid-August.

Salway. Large, yellow with crimson cheek, one of the best late peaches. October.

Salberta. A new variety. About a week later than the Elberta. Very hardy and productive.

Stearns. Similar to the Elberta but of better quality, and hardier. A comparatively new variety, but is proving to be one of the best. September.

Stump. A beautiful red and white peach of good size and flavor. Very productive. September.

Yellow St. John. Large, yellow with red cheek; fine flavor, very productive. Early August.

Wilma. Splendid new variety. Fruit as large as Elberta, not quite so elongated; better color and ripens about ten days later.

\section{APRICOTS}

A most delicious fruit of the plum species. Is of a distinct flavor and one of our best and most profitable market fruits. The tree bears young and most profusely. Ripening as it does between the cherries and peaches, the apricot is a most welcome fruit. In very sunny localities it is apt to bloom too early in the spring and be caught by the frost. The tree is slender in form. has beautiful dark-green foliage, pretty pink blossoms, and gives very satisfactory results as an ornamental tree in any garden or house lot. To avoid being caught by late spring frosts, spread long strawy manure about one foot thick around the trea in winter.

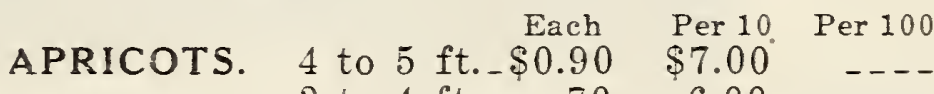

$$
3 \text { to } 4 \mathrm{ft} \text {. } \quad .70 \quad 6.00
$$

Moorpark. Large, orange with red cheek. August.

Royal. Large, yellow with red cheek. Late July.

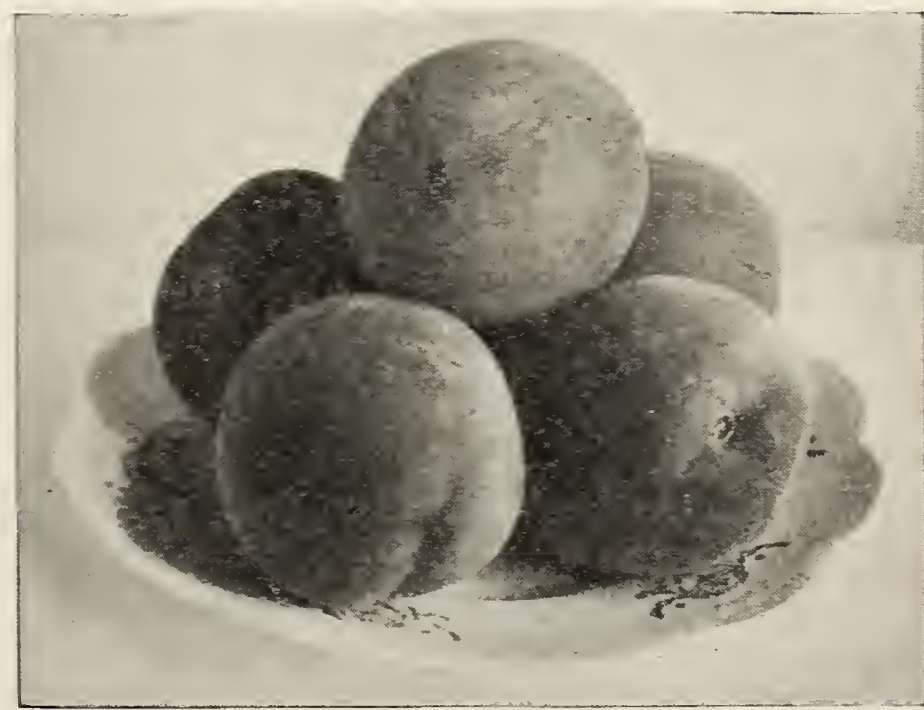

Elberta 


\section{QUINCES}

The quince is always in demand, although its commercial value has changed but little for many years. Quinces are largely used in cooking, canning and preserving, as they have a delicious flavor. It is a reliable cropper, and requires but little care. Yet the increased size of the fruit and the quality repay well for all the extra work given them. The trees thrive in almost any soil, but prefer a heavy, moist, clay loam.

$\begin{array}{rrrrr} & & \text { Each } & \text { Per } 10 & \text { Per } 100 \\ \text { QUINCES. } \quad 4 \text { to } 5 \mathrm{ft.} \$ \mathbf{\$ 0 . 9 5} & \$ 8.50 & \$ 75.00 \\ & 3 \text { to } 4 \mathrm{ft.}- & .85 & 7.50 & 65.00\end{array}$

Orange. Large, round, bright golden yellow and very productive. The best market quince. October.

Champion. Large, oblong, bright yellow, russet around the stem. Tree early and annual bearer. Later than the Orange.

\section{PEAR TREES}

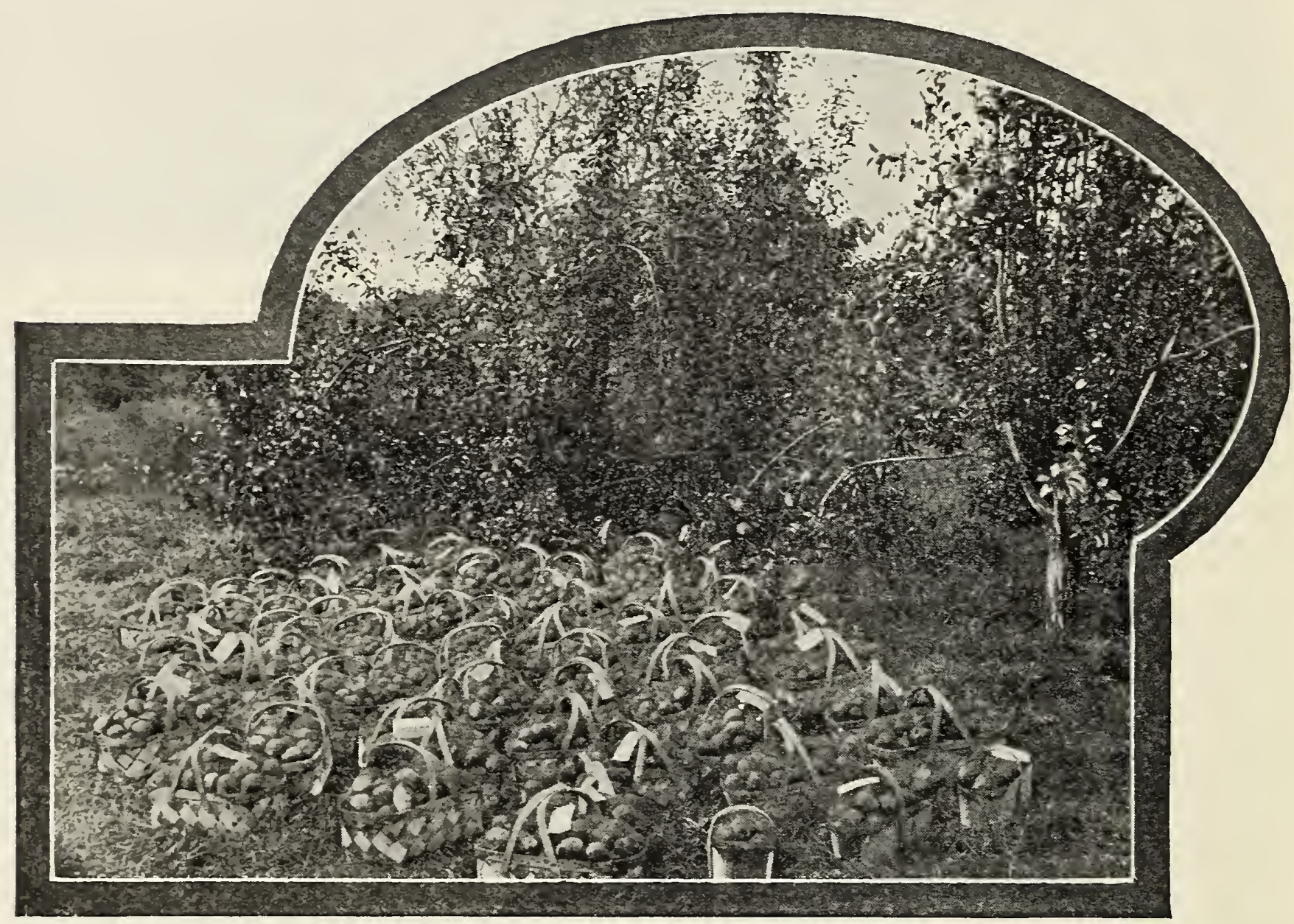

$\mathbf{P}$

EARS, like plums, do best on a loam or clay soil, and should be planted from 15 to 20 feet apart. They begin to bear from 3 to 5 years after planting. For permanent orchards the standard trees are the best, but for small lots and home gardens the dwarf trees are much used. The dwarf trees are those grown or propagated on quince roots; causing the tree to grow smaller, and some varieties are very good grown in this manner.

Some points in favor of pears are: they begin bearing in a very few years after planting; seldom miss bearing at least a partial crop, for which there is always a ready sale, besides they are one of the most healthful of our fruits.

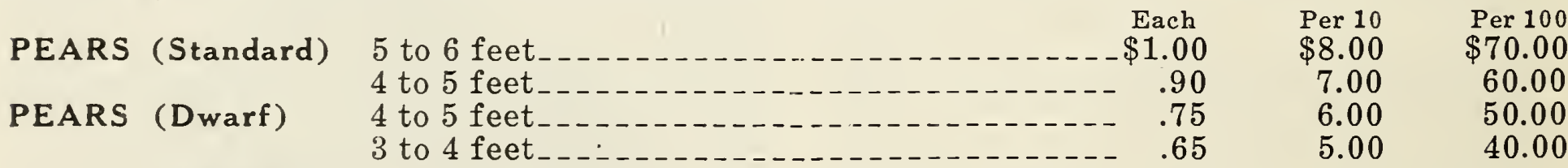

\section{SUMMER VARIETIES}

Bartlett. Large, coloring when fully ripe to waxy yellow with a red blush, juicy, melting, highly flavored. Bears early and abundantly. The leading market variety. Good either as a dwarf or standard. August and September.

Clapp's Favorite. Large, yellow flushed with red next to the sun; juicy and delightful.
Earlier than the Bartlett.' Tree vigorous, hardy and productive. August.

Mary. One of the best early pears. Red cheeks. Best quality.

Tyson. Medium size; yellow with russet shadings; melting, sweet and rich. August.

Wilder. Medium size; pale yellow with shadings of russet-red; melting and delightful, abundant bearer. Early August. 


\section{AUTUMN VARIETIES}

Buerre D'Anjou. A large greenish pear shaded with russet-crimson; highly flavored and very productive. One of the best fall pears. October and November.

Duchess D'Angouleme. Very large, greenish yellow spotted with russet; flesh white, juicy and rich. We recommend it as one of the best for market and home use. Especially good as a dwarf. October and November.

Flemish Beauty. Large, handsome, luscious flavor. Tree vigorous and hardy, bears early and abundantly. September and October.

Howell. Fine size, bright color, excellent quality; tree vigorous and bears early. September and October.

Keiffer. Large, fine appearance, good shipper and keeper; trees bear early and abundantly. October and November.

Seckel. Beautiful and delicious; one of the richest and highest flavored pears known. Small. September and October.

Sheldon. A large, round, russet and red pear of fine quality; excellent flavor, sweet and rich. October.

Worden Seckel. A seedling of the Seckel, as good in quality, but larger in size and a better keeper. October and November.

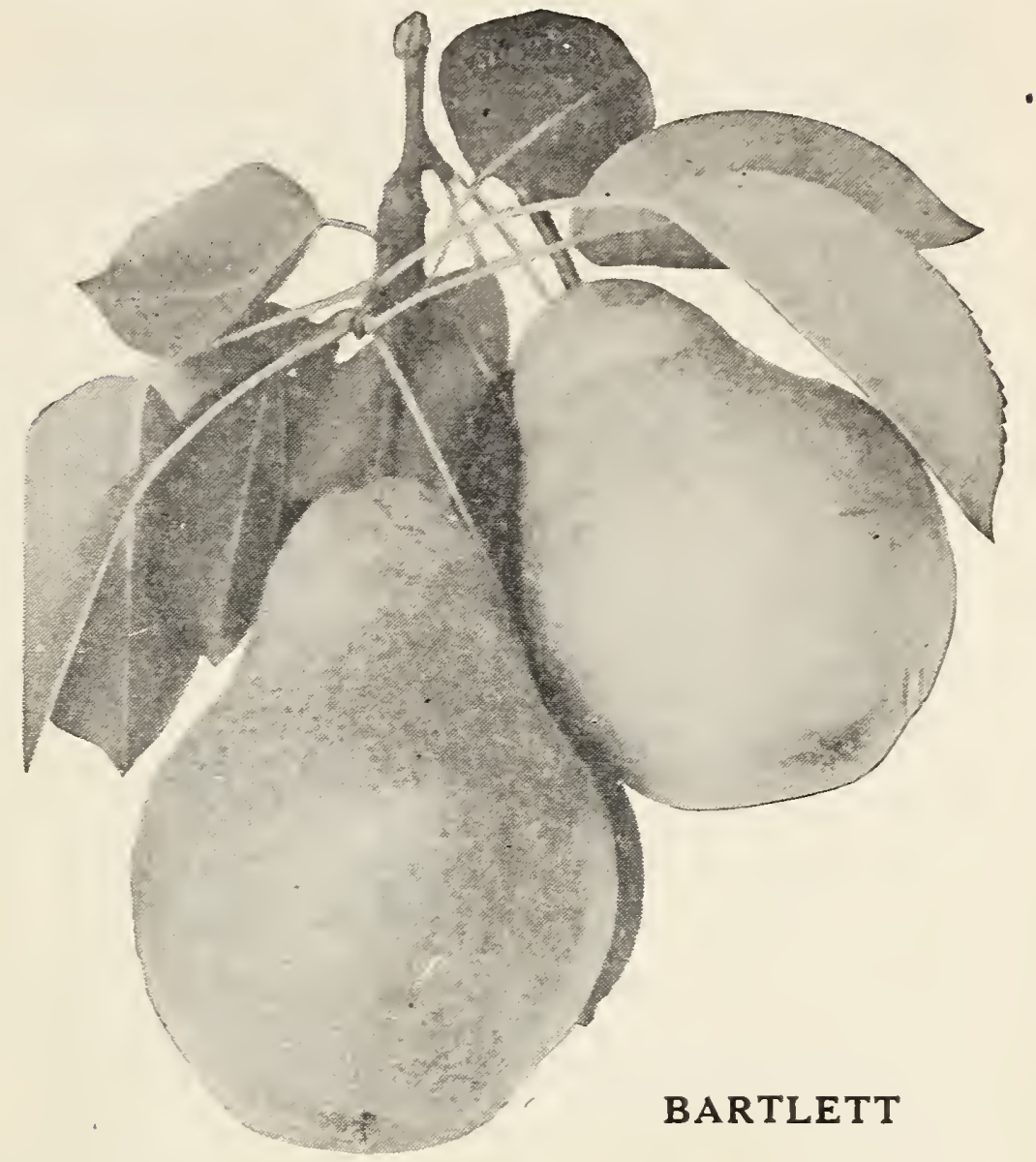

WINTER VARIETIES

Lawrence. Medium to large size; golden yellow with melting aromatic flesh. The best winter pear. Tree hardy and productive. November and December.

\section{PLUMS}

$\mathbf{W}$ ITH only reasonably good care and culture, plum trees can be kept in healthy condition, and will produce fine crops of iruits. The market for plums is never overstocked, and they always bring good profitable returns. Plums do best on loam or clay soil, and should be planted from 15 to 20 feet apart. They will begin to bear from 3 to 5 years after planting.

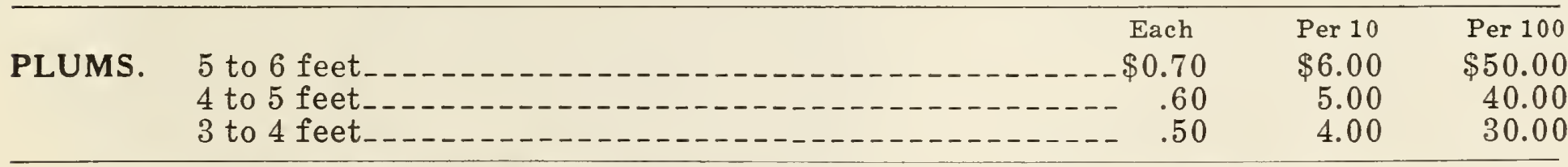

\section{EUROPEAN VARIETIES}

Archduke. Reddish-purple changing to a dark blue; flesh golden yellow, juicy; good flavor. Early October.

Bradshaw. Very large, purplish-red changing to dark reddish purple; flesh dull yellow, juicy, sweet and good. Middle of August.

German Prune. Large, long-oval, purplish black; flesh yellowish green, sweetish, mild and pleasant flavor. September.

Grand Duke. A valuable late plum, reddish purple or purplish black; flesh is golden yellow, juicy, firm, sweet, mild, and good. Late September.

Gueii. Dark purplish black, flesh golden yellow, firm and sweet. Vigorous, hardy and productive. Early September.
Italian Prune. (Fellenburg.) One of the leading plums of western New York. Sometimes known as York State Prune. Is purplish black, flesh golden yellow, very good quality. Productive. Late August.

Lombard. Medium to large, purplish red; flesh yellowish, juicy, firm and sweet. Vigorous and productive. Late August.

Monarch. Large, dark purplish red; flesh yellow, juicy and tender. October.

Reine Claude. (Bavay's Green Gage). Large, roundish oval, green, marked with red in sun; flesh yellow, juicy, excellent flavor. Late September. 
Shippers Pride. Large, purplish black; flesh greenish yellow, firm and sweet. A good keeper and shipper. September.

Shropshire Damson. The largest of the Damsons. Purplish black, flesh golden yellow. Very productive. October.

Yellow Egg. Large, golden yellow; juicy, mild and good. Late August.

\section{JAPANESE VARIETIES}

Abundance. Medium size, amber with markings of red; juicy and sweet. Productive. August.

Burbank. Large, deep cherry red; sweet and firm. Tree vigorous and productive. August.

Red June. Large, deep red, slightly sub-acid. Early August.

Wickson. Largest of the Japan Plums. A bright cherry red; flesh thick, sweet and tender. September.

\section{NUT TREES}

On the market, nuts are always in demand and command good prices. There is hardly another branch of tree cultivation from which there is assured such substantial profits. Not only are you each year reaping a large harvest of nuts but at the same time the trees themselves are growing into many dollars in the form of lumber.

American Sweet Chestnut. The native American Sweet Chestnut. It is useful both for ornamental purposes and for timber. The nuts are sweet and very desirable to grow for commercial purposes. No farm should be without its chestnut grove.

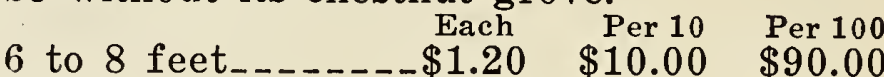

5 to 6 feet..... $1.00 \quad 9.00 \quad 80.00$

Merriman Chestnut. This is a cross between the Paragon Chestnut and the American Sweet. It is perfectly hardy and vigorous and enormously productive. Nuts of immense size, measure three inches in circumference and sometimes more. It was originated within a mile of our nursery, and we think it is one of the most desirable trees for planting that was ever introduced.

Each Per 10 Per 100

$\begin{array}{llll}\$ 1.50 & \$ 13.50 & \$ 125.00\end{array}$

English Walnut. Although not always hardy in our northern climate, they are desirable trees to grow.

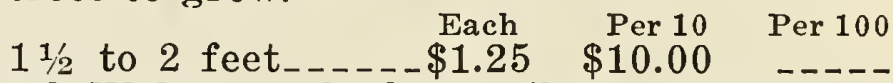

Black Walnut. The large oily nuts are borne in heavy crops. The tree grows quite fast and its dark rich wood is exceedingly valuable.

2 to 3 feet__ $\begin{array}{ccc}\text { Each } & \text { Per } 10 & \text { Per } 100\end{array}$

Butternut. Native tree, producing a large nut. Has a sweet, oily, nutritious kernel.

3 to 4 feet__. $\begin{array}{rr}\text { Each } & \text { Per } 10 \\ \$ 6.00\end{array}$

4 to 5 feet.

\section{GRAPE VINES}

There should be Grape Vines in every home garden. For commercial purposes grapes are a very profitable venture. With but little care they will bear fruit, but good culture, pruning and spraying are well repaid by the best quality of fruit.

One of the most satisfactory crops that can be grown, because it can be depended upon practically every year. Grape vines will grow almost everywhere, but to produce the finest specimens they should be carefully cultivated and pruned. A south or southwestern exposure will give best results. The soil should be dry, if not, should be artificially drained before planting.

A top dressing of well-rotted manure should be applied every year, alternated every few years with a dressing of slaked lime.

Grapes can be easily trained over fences, buildings, arbors, pergolas, etc., and in this way are ornamental as well as useful. The enemies of the grape vine and fruit are few and can be easily kept in check.

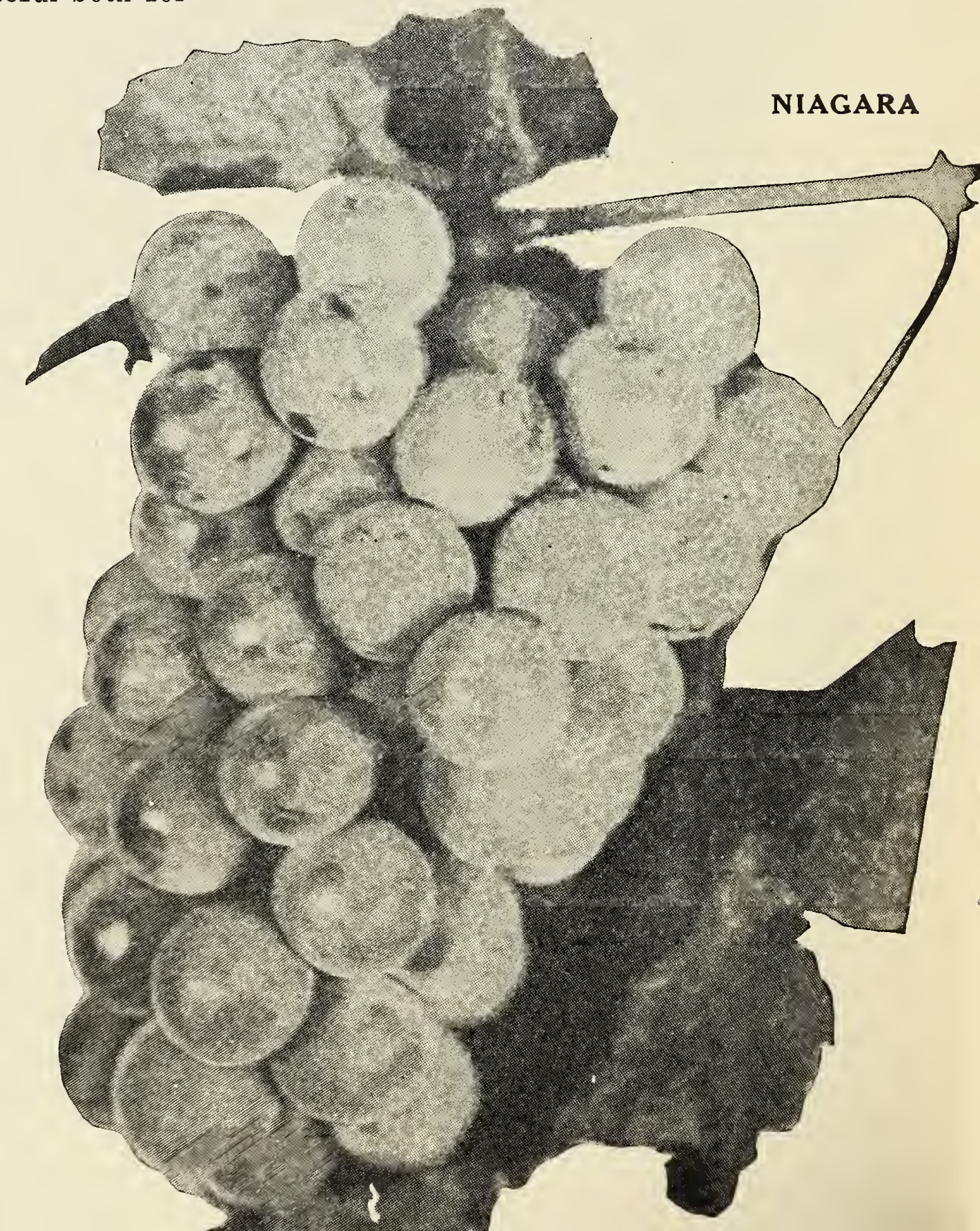




\section{WHITE VARIETIES}

Diamond. A very desirable variety. Earlier than Niagara. Green with a tinge of yellow.
1 year
Each
Per 10
Per 100
2 years
.25
2.25
20.00

Pocklington. Clusters and berries large, fairly hardy, productive; yellowish green with a tinge of amber. A little later than the Concord.

1 Eear._. $\begin{array}{rrr}\text { Each } & \text { Per } 10 & \text { Per } 100 \\ \$ 2.50 & \$ 20.00\end{array}$ 2 vears........ $\quad .40 \quad 3.50 \quad 25.00$

Niagara. The best of the white grapes. Clusters large and handsome. Light green changing to pale yellowish green; excellent quality; hardy. Ripens with the Concord.
1 year Each Per 10
Per 100
2 vears $-\$ 0.20$
$\$ 1.50$
$\$ 10.00$

\section{BLACK VARIETIES}

Campbell's Early. One of the newest varieties. Large, handsome, productive, dark purplish black, rather dull. One of the best early varieties.

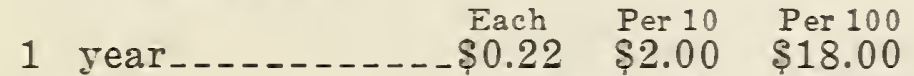
2 vears._........ $.30 \quad 2.75 \quad 25.00$

Concord. The leading variety for the market. Large, handsome clusters of big berries of good quality. One of the best known. $\begin{array}{rrrr}\text { Each } & \text { Per } 10 & \text { Per } 100 \\ 1 \text { year__._._._. } \$ 0.12 & \$ 1.00 & \$ 6.00\end{array}$ 2 years

Ives. Very hardy and productive. Very desirable for grape juice or wine. Jet black with blue bloom.
1 year
Each
Per 10
10 Per 100
vers._._. $\quad .25 \quad 2.00 \quad 16.00$

Moore's Early. Clusters of medium size; berries large, round, dark purplish black. One of the best early grapes.

$\begin{array}{rrrr} & \text { Each } & \text { Per } 10 & \text { Per } 100 \\ 1 \text { year__._._._. } 0.25 & \$ 2.00 & \$ 15.00 \\ 2 \text { years_._. } & & \end{array}$

Worden. Seedling of the Concord, but larger in bunch and berry and of superior flavor, about ten dars earlier. Dark purplish black to black.

$\begin{array}{rrrr} & \text { Each } & \text { Per } 10 & \text { Per } 100 \\ 1 \text { year__._._. } \$ 0.20 & \$ 1.50 & \$ 12.00 \\ 2 \text { years_._. } & & \end{array}$

\section{RED VARIETIES}

Agawam. A little later than the Concord. A good keeper. Dark purplish red.

$\begin{array}{rrrr}\text { Each } & \text { Per } 10 & \text { Per } 100 \\ 1 \text { year____-_.-\$0.15 } & \$ 1.20 & \$ 10.00 \\ 2 \text { years__. } & \$ 20 & 1.50 & 13.00\end{array}$

Brighton. Bunches large, well formed; flavor and quality good; ripening with the Delaware. Light and dark red.

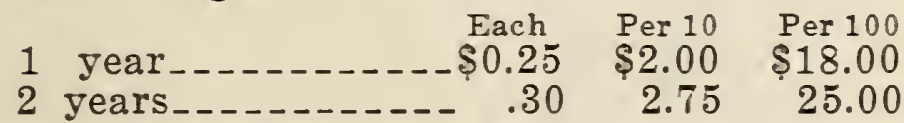

Caco. A new rariety. It is a cross between the Catawba and Concord. Fruit rery large, rich wine red over amber. Exceptionally rich sugary flavor.
Each Per 10

1 year_...

Catawba. One of the standard table wine grapes; good sized berries and good clusters. Late. Requires long season. A good keeper. Dull red.

$\begin{array}{rrrr}\text { Each } & \text { Per } 10 & \text { Per } 100 \\ 1 \text { year__. } & \$ 0.16 & \$ 1.40 & \$ 12.00\end{array}$

2 rears......... $.25 \quad 2.00 \quad 18.00$

Delaware. A choice native grape; bunches and berries are small but compact; of the best quality; light red. Very hardy.

Each Per 10 Per 100 1 year.......... \$0.25 \$2.00 \$18.00 2 years_......... .30 $2.75 \quad 25.00$ Salem. A little earlier than the Concord; it keeps and ships well; large fruit, round, rery dark red with blue bloom. Very good. Each Per 10 Per 100 1 year_......... \$0.20 \$1.50 \$12.00 2 years......... $25 \quad 2.00 \quad 15.00$ Wyoming. A Week or ten dars earlier than The Concord. Dark, dull red with lilac bloom.

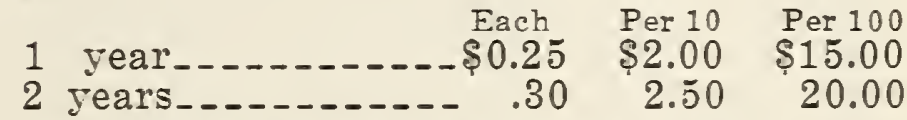

\section{GOOSEBERRIES}

Gooseberries should be planted in good, rich soil and well manured once a year. Pick regularly, thoroughly cutting out all deadwood and surplus branches. Plant in rows 4 feet to 6 feet apart in rows. It is well to mulch heavily in the fall. Plants are hardy, rugged and easily grown.

Chautauqua. Large white gooseberries. Very fine.

$\begin{array}{rrrr}\text { Each } & \text { Per } 10 & \text { Per } 100 \\ 1 \text { year__._._._. } \$ 0.35 & \$ 3.00 & \$ 25.00 \\ 2 \text { years_._. } & & \end{array}$

Downing. A large, handsome, light green berry of excellent quality. Very vigorous and productive.

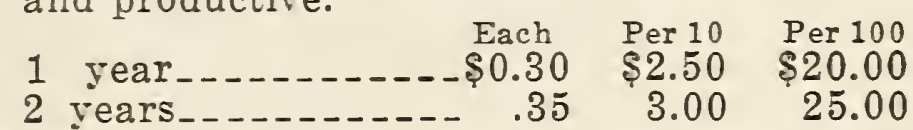

Houghton. Fruit medium size, pale red, good.

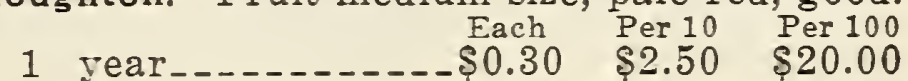
2 Fears_........ . .35 $3.00 \quad 25.00$

Josselyn. Large, hard8, bright red.

Each Per 10 Per 100

1 year _........ \$0.40 $\$ 3.50 \quad \$ 30.00$ MULBERRIES

The Mulberries are both fruit and ornamental trees. While few people care for then alone ther add a wonderful flavor when cooked with other fruit. As their fruit ripens over a long period they are doubly valuable. Mulberries. (Russian)

4 to 5 feet__. $\begin{array}{ccc}\text { Each } & \text { Per } 10 & \text { Per } 100 \\ \$ 0.60 & \$ 5.00 & \$ 40.00\end{array}$

New American and

Downing.

$\begin{array}{ll}5 \text { to } 6 \text { feet_--- } & 1.00 \\ 4 \text { to } 5 \text { feet } & .90\end{array}$

Russian. Is rery hardy. Much used for wind break. Fruit of very little value.

Downing. Is very prolific. Fruit large, black, sub-acid.

New American. Vigorous. Very prolific. 


\section{CURRANTS}

The currant is one of the $\mathrm{m}$ o s t reliable of small fruits. $\mathrm{T}$ h e y mature just b e f o r e raspbe $\mathrm{r}$ i e $\mathrm{s}$ and $c$ a $n$ be $u$ s e d either raw or cooked. Being hardy, the $y$ do not winter kill, are easy of cultivation and require little care. They can be grown in any good garden soil, about four feet a part. The market is $n$ e ver oversupplied. Prune out dead wood, a nd $\mathrm{mulch}$ $\mathrm{h}$ e a vily. If currant worms appear, du s t with hellebore.

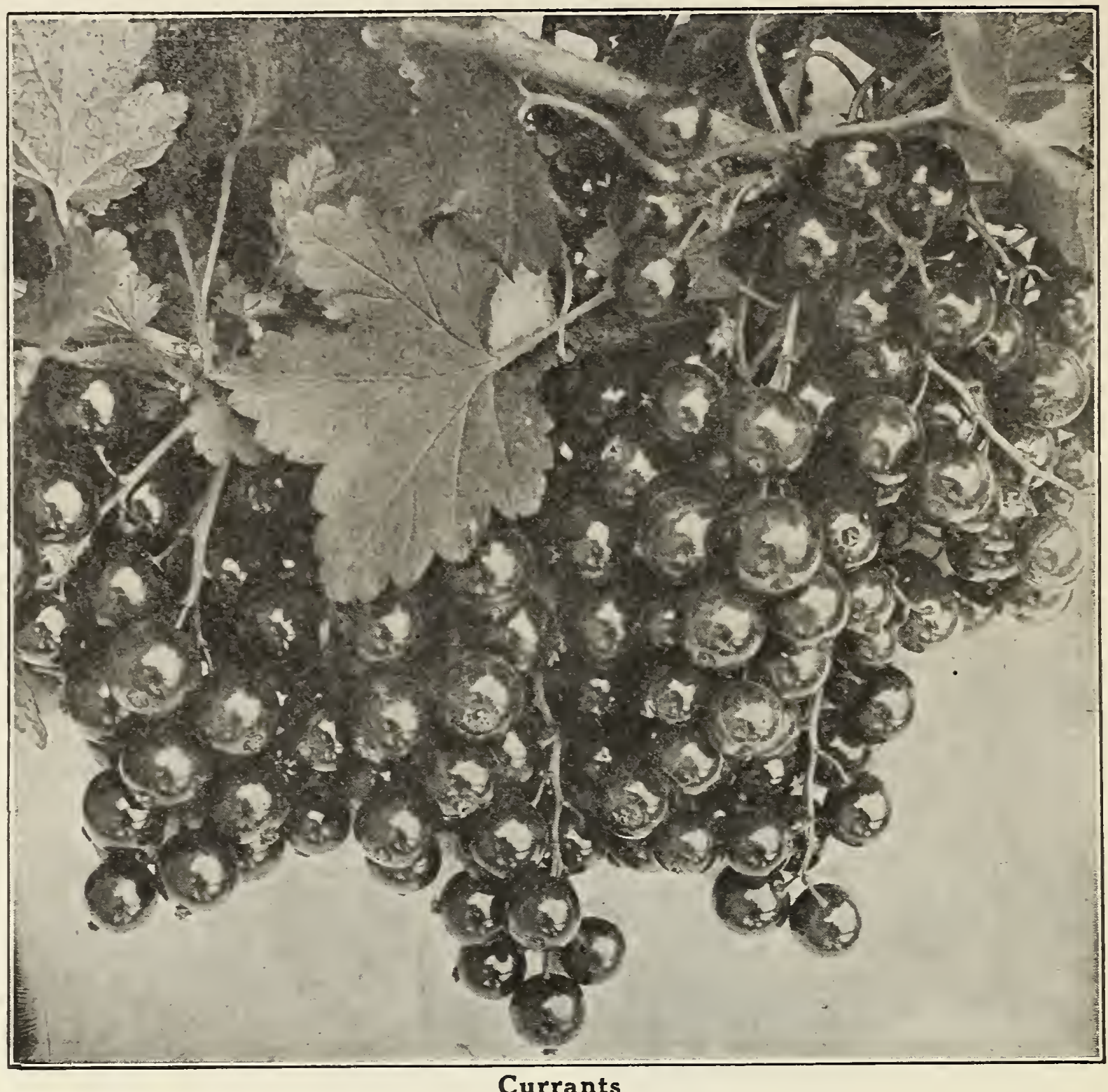

\section{RED VARIETIES}

Fay's Prolific. Extra large, long stems and berries. Very productive.

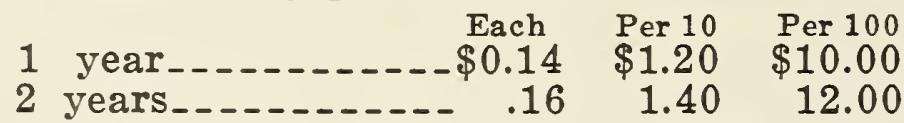

Perfection. Beautiful bright red, larger than the Fay's. Very productive.

$\begin{array}{rrrr} & \text { Each } & \text { Per } 10 & \text { Per } 100 \\ 2 \text { year__._._. } \$ 0.25 & \$ 2.25 & \$ 20.00 \\ 2 \text { years__. } & & \end{array}$

London Market. Hardy, good color and size. Heavy cropper.

$$
\begin{aligned}
& 1 \text { Each Per } 10 \text { Per } 100 \\
& 2 \text { years }
\end{aligned}
$$

wilder. The very best, bunch and berry very large, enormously productive, a strong grower. Will hang on the bushes in good condition for some time after ripening.

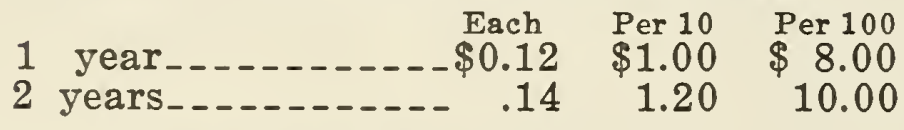

\section{WHITE VARIETIES}

White Grape. Large, handsome clusters of yellowish white berries. Best quality.
1 year
Each
2 years
$\$ 0.16$
Per 10 Per 100
$\$ 1.40 \$ 12.00$
$1.80 \quad 15.00$

\section{BLACKBERRIES}

Blackberries are one of the most profitable of our small fruit crops, and should be grown on every farm and fruit plantation.

The blackberry thrives well in almost any soil, but to reach perfection, demands a strong loam, tending towards clay, rather than sand. In many parts of the country, winter protection is a necessity and often adds greatly to the yield where not considered really essential. The pruning of the blackberry is not a difficult task, yet success depends upon the proper method. The old canes should be removed early; it is preferable in the summer after they have borne their crop of fruit. Cultivation should be frequent but shallow, as deep cultivation disturbs the roots and induces them to sucker. Pinch back the canes when three or four feet high. It is not best to allow more than three canes to a hill. Blackberries should be planted about four feet apart in rows seven feet apart.

Per 10 Per 100 Per 1000 $\$ 0.75 \$ 6.00 \quad \$ 50.00$

Blower. Originated in the fruit belt of western New York and has been thoroughly tested for several years. It has proven to be perfectly hardy and very productive. The fruit is of the finest quality, large size, jet black, and a good shipper.

Early Harvest. One of the first to ripen, very productive, but sometimes winter kills in the north. 
Eldorado. The vines are very hardy and vigorous, and enormously productive. The berries are large, jet black, borne in large clusters and are very sweet.

Mersereau. A strong grower and is claimed to be the hardiest blackberry, standing uninjured 20 degrees below zero. Very productive, of good size, berries of excellent quality. Ripens late.

Snyder. Medium size. Hardy, early.

Taylor. Berries of fine flavor and large. Canes vigorous, of ironclad hardiness, very prolific. Ripens late.

\section{RASP. BERRIES}

Raspberries will do well in any soil not too wet. Keep cultivated and free from weeds; old canes should be cut as soon as done bearing, to give vigor to the new wood. Plant in rows six feet apart, three feet apart in the row.

\section{Purple Varieties}

Columbian. Very large, purplish $r$ ed, go od flavor, enormously productive, strong grower. 60 cts. per $10 ; \$ 4.00$ per 100.

\section{Black Varieties}

Cumberland. The best of all the black caps. Fruit very large, of the best quality, firm and handsome, canes healthy, hardy and vigorous. 50 cts. per $10 ; \$ 3.50$ per 100 ; $\$ 25.00$ per 1000 .

Farmer. (Plum Farmer.) Large, black, said to be as large as the Cumberland and as productive, and about the same season. 50 cts. per $10 ; \$ 3.50$ per $100 ; \$ 25.00$ per 1000 .

Kansas. Early variety. We consider it the most dependable variety known. Berries jet black and of the best quality; canes vigorous, free from disease and hardy. 50 cts. per $10 ; \$ 3.50$ per $100 ; \$ 25.00$ per 1000.

Munger. A very fine new blackcap. Larger, hardier, and more productive and of better quality than the Gregg. About a week later

than that variety. Was first grown in western Ohio from a seed of the Shaffer.

50 cts, per $10 ; \$ 3.50$ per $100 ; \$ 25.00$ per 1000 .

\section{Red Varieties}

Cuthbert. The leading market red variety. The berries are of large size and bright red in color; very productive. The canes are vigorous and healthy.

50 cts. per $10 ; \$ 3.50$ per $100 ; \$ 25.00$ per 1000 .

King. Earlier than the Cuthbert. Large bright red; very productive. 50 cts. per $10 ; \$ 3.50$ per 100 .

St. Regis. Continuous-to-fall bearing red raspberry. The fruit ripens with the earliest and continues until October. Bright crimson, large size. 50 cts. per $10 ; \$ 3.50$ per 100 . 


\section{RED VARIETIES}

June. Tested with seventy other varieties at the New York Experimental Station, this unusual new berry was the only one to bear fruit in June, and in this manner its name was gained. Besides its early bearing, there are other remarkable advantages. It is quite thornless! Berries are bright red, larger than Cuthbert, and are borne in great profusion over a long period.

80 cts. per $10 ; \$ 6.00$ per $100 ; \$ 50.00$ per 1000 .

Herbert. Hardy, bright red, fine flavor. 80 cts. per $10 ; \$ 6.00$ per 100 .
Latham. This is a camparatively new variety but is considered one of the very best Red Raspberries grown. Ripens with Cuthbert and is enormously productive. Berries much larger than any other Red Raspberry, many of them one inch in diameter. Berries dark red and of fine quality. $\$ 1.00$ per $10 ; \$ 7.50$ per $100, \$ 50.00$ per 1000 .

\section{YELLOW VARIETIES}

Golden Queen. Berries large, a beautiful pale amber yellow. Canes hardy, of the strongest growth and productive. 80 cts. per $10 ; \$ 6.00$ per 100 .

\section{STRA WBERRIES}

Our Strawberry plants are taken from beds set especially to produce plants. Each variety is kept by itself. Our soil is especially adapted to growing strong and healthy plants, and we have been very successful in that line.

Strawberries will succeed in any soil that is adapted to ordinary farm or garden crops. Soil should be thoroughly prepared to a good depth, well drained and fertilized. For field culture, set in rows 3 or $31 / 2$ feet apart, 15 to 18 inches in the rows; for garden, 15 inches apart each way, leaving a pathway every third row. The pistillate.

Strawberries

Per 100 Per 1000

Aroma. (Per) Plant shows no weakness of any kind. Fruit very large, roundish, conical, rarely misshapen, glossy red, of excellent quality and produces in abundance. Standard variety.
Belt. (Per) Very large conical, bright red, good flavor; the plant is strong, healthy and productive. One of the best berries. Season medium to late.

Dunlap. (Senator Dunlap) (Per) The great home and market berry of the present day. Large deep red, very firm and of excellent quality. Very early and bears nearly a month.

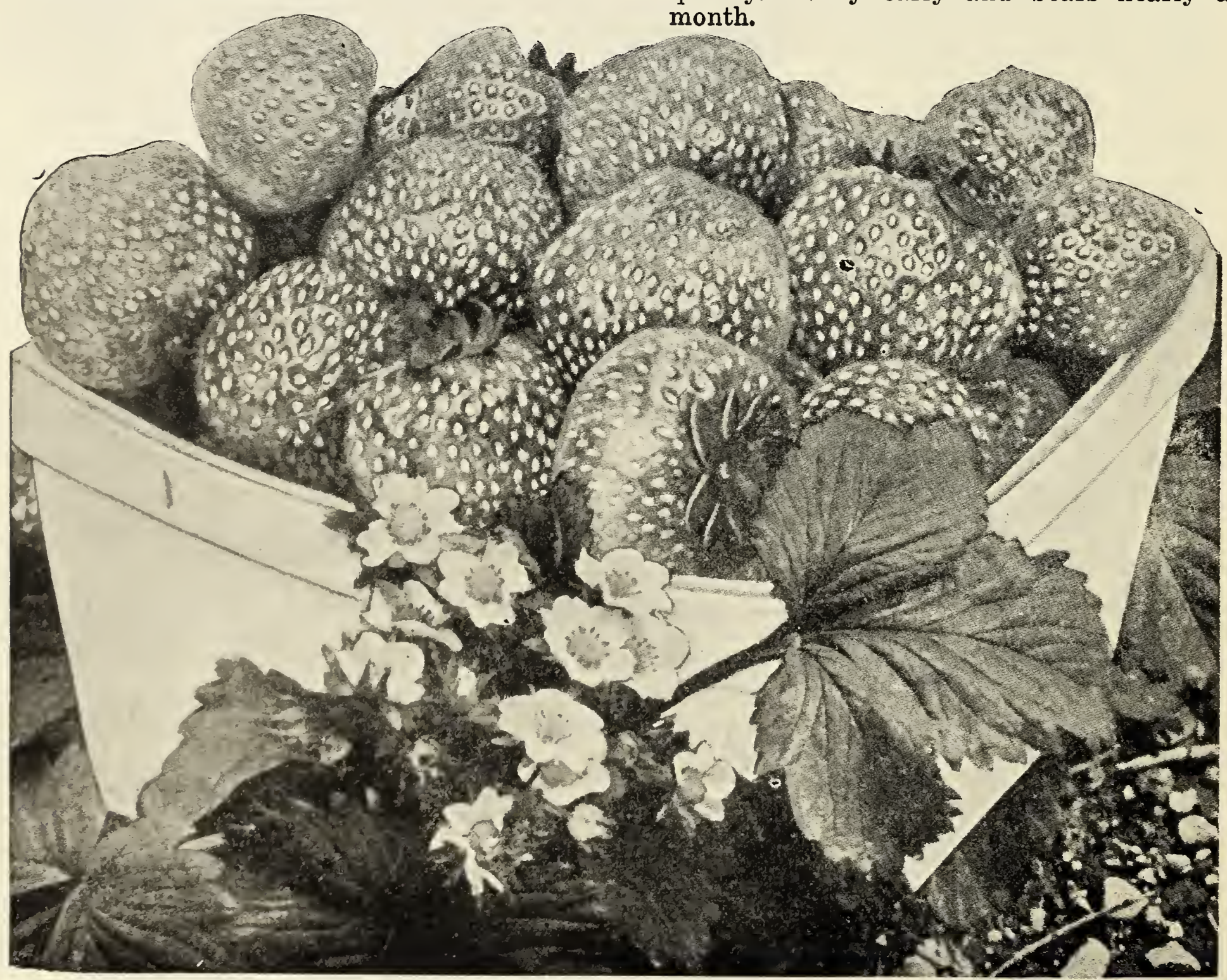


Gandy. (Per) One of the leading market sorts; color bright crimson, uniform in size and shape; large and firm; plants $\mathrm{vig}$ or ou s and healthy.

Glen Mary. (Per) Fruit large sweet, rich, good color. Plants vigor ous and productive. Is firm and a good shipper.

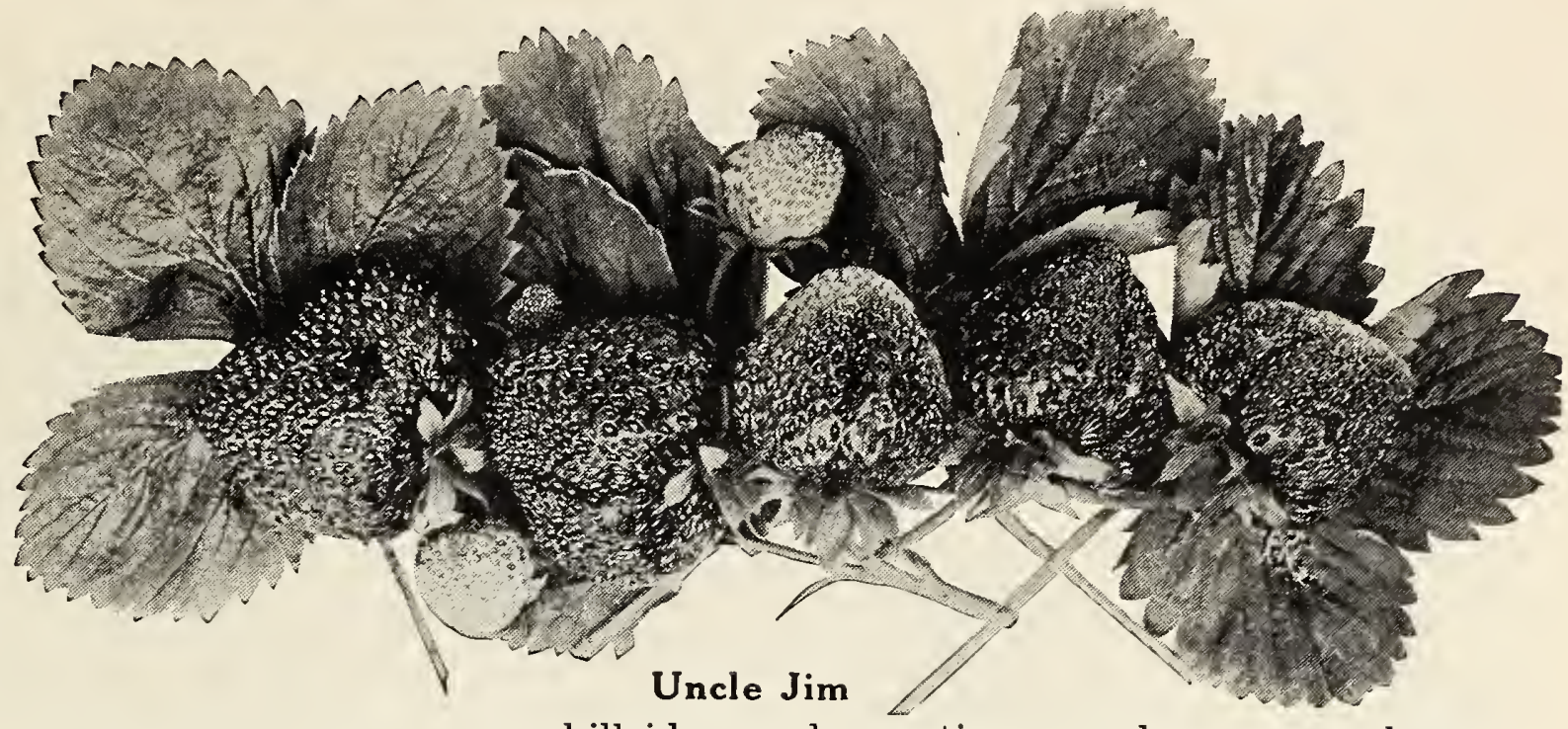

Gibson. Berries large, fine flavor, a deep red color. Midseason.

Jessie. (Per) Very large, handsome, dark red. On some soils very productive.

Premier. (Per) The finest early berry; large size, fine quality, handsome appearance.

Parsons. (Per) Very large, bright red, firm, a good shipper. A fine large plant and very productive. A very profitable berry. Midseason.

Sample. (Imp) The leading market variety of today. Large size, good color, heavy cropper.

Uncle Jim. (Per) One of the newest varieties; very large; beautiful color; excellent quality. A very valuable berry.

\section{EVERBEARING VARIETIES}

Everbearing varieties are receiving a great deal of attention and berries being picked all through the fore part of October. The Everbearing berries should be transplanted each year in order to insure their fruiting, but the extra time and attention is well repaid by the luscious results.

Everbearing Strawberries have proved one of the greatest horticultural finds of the century. 500 plants will not only supply the home with delicious strawberries from early spring until freezing weather in the fall, but give a surplus for canning or market. After the second spring crop it has been found more profitable to plow the bed up and set a new one.

Per 100 Per 1000

Everbearing Varieties_._._. $\$ 1.50 \quad \$ 10.00$

Superb. Very large, dark red and glossy, fine quality. It begins to bear in June with immense crops and continues until late in the fall. It is one of the heaviest bearers of berries in June as well as a remarkable fall bearer. Will produce a fair crop of fruit first summer.

Progressive. (Per) One of the finest berries of the market today. Everbearing; fine color; shapely; delicious. Will bear fruit until late October. A very desirable variety for the home garden from the fact that it bears great quantities of fruit.

\section{DEWBERRIES}

The Dewberry is a trailing or vine form of the blackberry. May be trained to run over stone piles, over rough embankments or rocky

hillsides, and sometimes produce a very large crop of fruit annually over land where no other crop could be grown. The fruit is very large and always at a premium with the commission men or the open market. Should be protected in winter with a coarse litter.

Lucretia Dewberry. One of the low growing trailing blackberries; large berries and ripens early. 30 cts, per 10, $\$ 2.50$ per 100 .

\section{RHUBARB}

Ranks among the very best of the early products of the garden. After the long, dreary winter months it furnishes the first material for fine pies and delicious table sauce. To produce tender and quick growth, the ground must be kept very rich.

Rhubarb Per 10 Per 100

Linnaeus. Leaf-stalks, large, tender, juicy; quite early.

Queen. The extra-large, tender stalks are a decided pink color, and splendid for canning.

\section{ASPARAGUS}

Every home with a garden, in the country or city, should have a good sized bed of asparagus. Nothing is easier to plant or care for, and its being among the first fruits of the garden makes it a universal favorite. In a commercal way the supply is always inadequate and the price high. Plant in rows, setting the roots 18 inches apart. Spread the roots out and plant with crown two inches below the surface of the ground, top-dressing annually with well rotted manure.

Asparagus. Columbian, Conover and Palmetto.

$$
\begin{aligned}
& \begin{array}{rrr}
\text { Per } 100 & \text { Per } 1000 \\
\$ \text { year. } & \$ 1.50 & \$ 10.00
\end{array} \\
& 2 \text { years _............. } 2.00 \quad 14.00
\end{aligned}
$$

Columbian Mammoth White. Strong, vigorous; large white shoots.

Conover's Colossal. Large, tender, deep green shoots.

Palmetto. A very early variety, very large and regular in size.

Washington. A new rust-resistant Asparagus. As a standard variety for the production of fancy asparagus for the home or market it stands ahead of all others in size, vigor, tenderness, and quality.

1 year

2 years

Per 1000

$\$ 12.00$ 


\section{Ornamental Department}

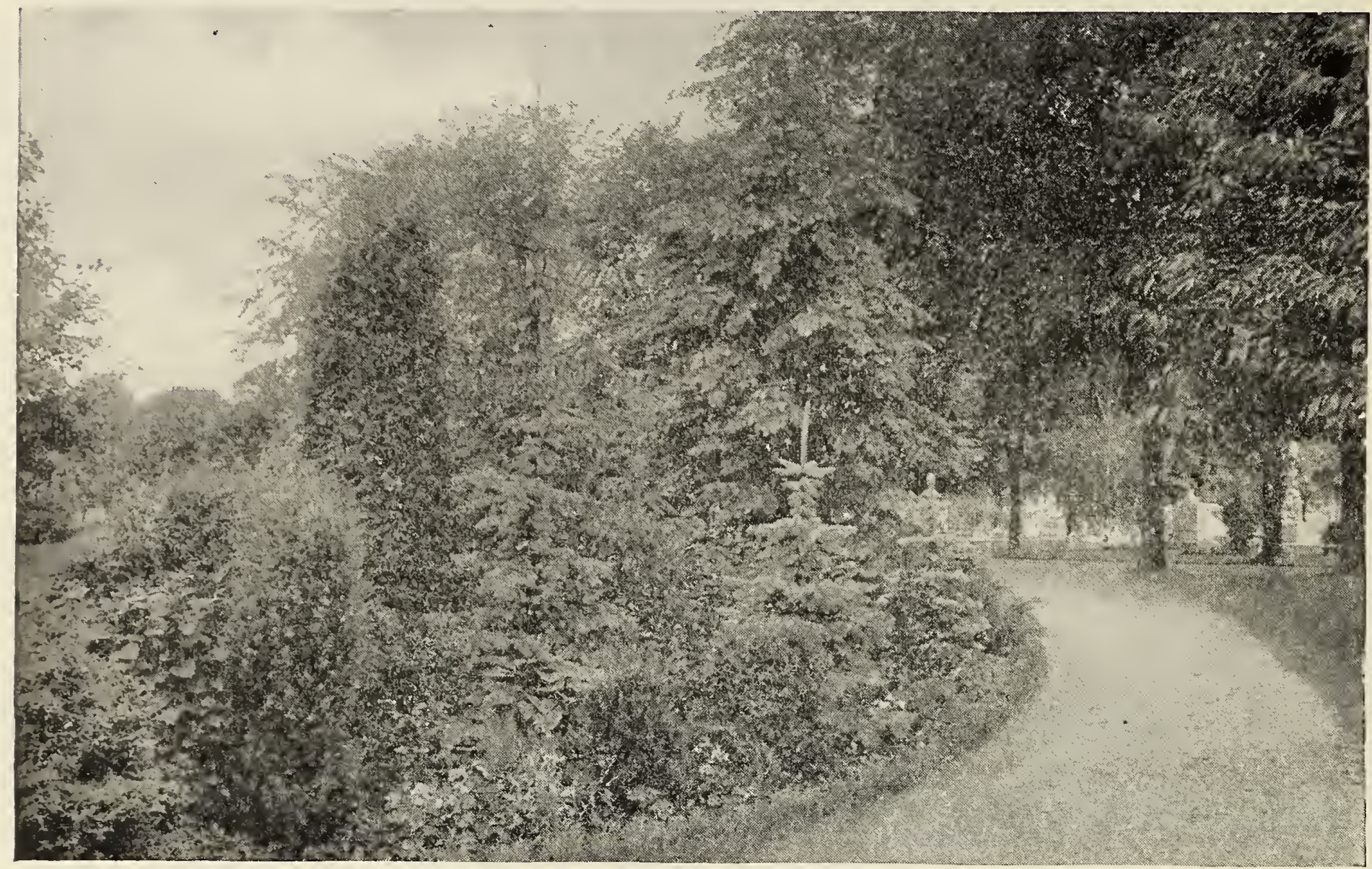

A Beautiful Arrangement of Shrubs and Perennials

I

T IS almost needless to say that trees and shrubs greatly increase the value of any property; yet you may ride through some of the best farming sections and find that the owners have given little, if any, attention to the home surroundings. Fortunately, the articles in the farm papers from time to time, combined with the efforts of the civic improvement societies, are having a noticeable effect in changing this situation.

The majority of men, whether in the country or in the city, do not need any arguments to convince them that home plantings will improve the looks of their place and add to their home comforts; the only reason that we can see why they have not taken advantage of these things is the belief that it takes too much money, too much skill and care to plan the grounds and plant them in proper order. This is an entirely wrong idea; the expense is comparatively slight, the labor of planting amounts to very little, and almost every home owner can make a reasonably good selection of trees and shrubs that ought to be around his place. Only on the very large places would the services of a landscape architect be needed.

Of course one ought to know something about the habits of the trees and shrubs used, and select those that are adapted to the location, to the soil, and to the climate; otherwise the results would not be altogether satisfactory. The foundation work can be screened with low-growing shrubs like the Barberry, Anthony Waterer Spirea, or with low-growing evergreens; at the curves in the drives and walks, clumps of evergreens, groups of flowering shrubs, or peonies may be used to advantage.

About the lawn, maples, evergreens and shrubs can be used with good effect and a Privet or Barberry hedge is far superior to the most elaborate fence.

The worst "barn of a place" can be changed into an attractive and desirable residence so far as the outside surroundings can make it so, and the merely expensive home can be changed to a really beautiful place. Each tree and shrub has a definite use and nine times out of ten the average home owner will select and place these trees and shrubs so that he secures at little cost the home appearance that he has so ardently longed for.

'Through the whole list of handsome and quick-growing trees and shrubs we have desirable specimens to offer. They have been grown on good soil, under the best conditions, and by men who understand growing deciduous and evergreen trees.

PLANTING HINTS-In preparing the ground for the trees dig at least two feet deep and three feet wide. Thoroughly mix the soil you take out, and then you can put about a foot of it back.

Start the trees 10 inches deeper than you want them to set. Sprinkle fine dirt in among the roots, and, as you continue to do this, jolt the tree up and down so as to settle the dirt in among the fine roots. As the hole fills up keep packing the dirt. Use a heavy maul and come down on the dirt with all your weight. You cannot get it too tight about the roots. 
The top inch or two of dirt, however, should be loose to conserve moisture. Trees finally should set just about two inches deeper than they did in the nursery.

After planting you may water the trees liberally. We strongly recommend that you mulch immediately underneath newly planted trees. Hay, cut straw, and strawy-manure are good material to use for this. A layer six inches thick is not too deep. Such a mulch will keep the ground damp all the time, and will prevent nearly all evaporation. Unless you use this mulch it will be necessary to hoe around the tree every week or so to keep a mulch of dust on the surface to conserve the moisture. The after-treatment is determined easily.

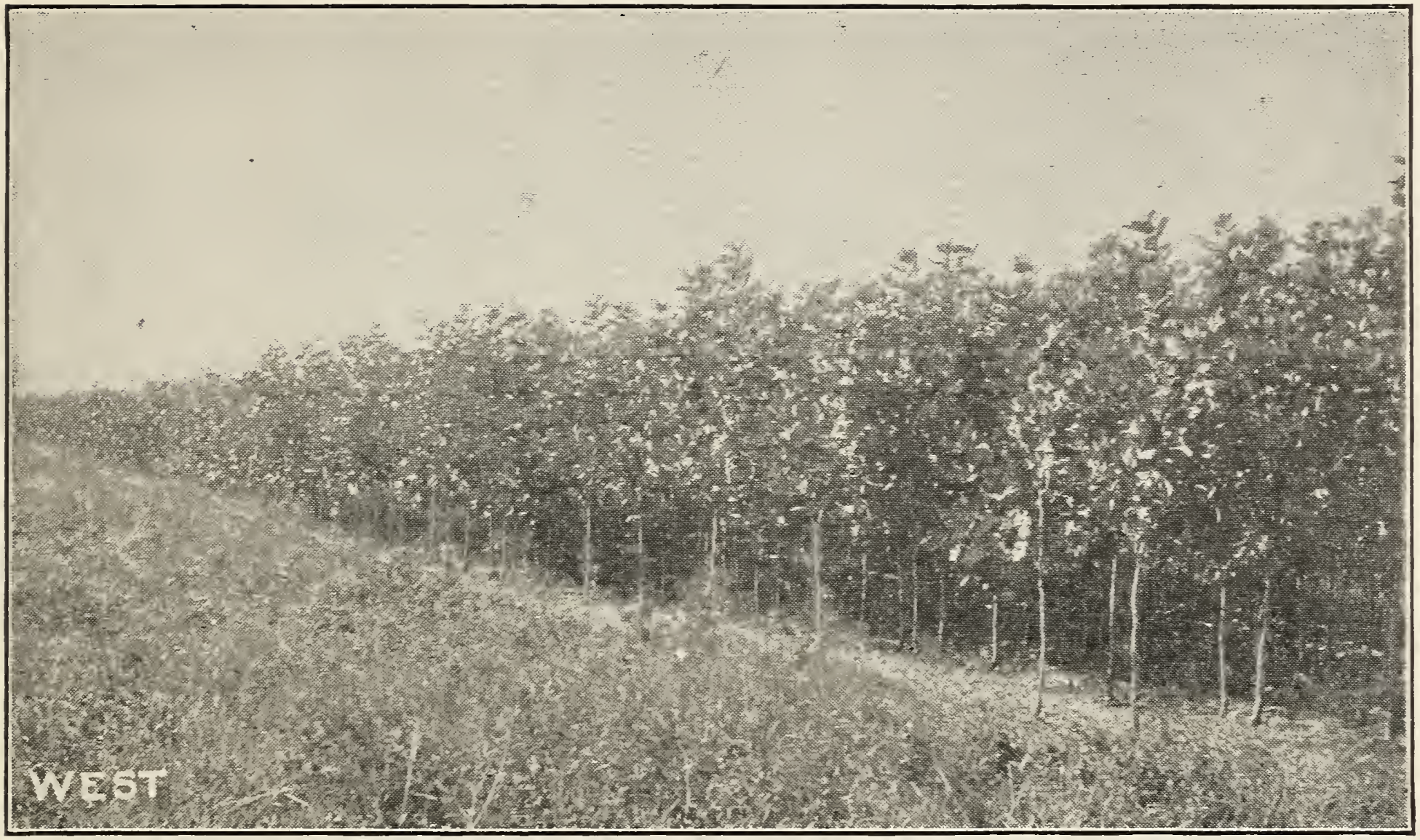

A Block of European Sycamore or Oriental Plane

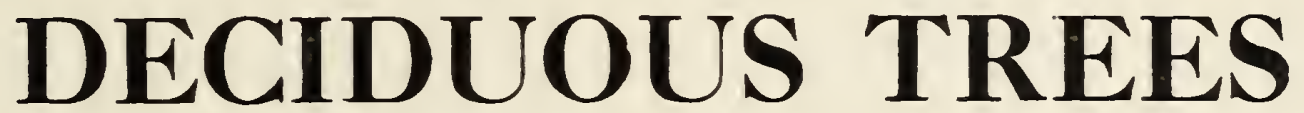

There are several good reasons for planting shade trees; they keep off the intense heat of the summer sun; they acord a cool spot where the children can play; they make the place more pleasing and they greatly increase the value of the home.

Talk it over with friend wife, decide to increase the beauty of your place, plant shade trees, now, this year, and in a few seasons you will begin to realize that the small cost of the trees was one of the best investments you ever made. Ailanthus Glandulosa. (Tree of Heaven.) A lofty, rapid growing tree with pinnate palm-like leaves. Free from disease.

$6-8 \mathrm{ft} .-\$ 1.50$ each; $\$ 12.50$ per 10 . $8-10 \mathrm{ft}$. - $\$ 1.75$ each; $\$ 15.00$ per 10 .

Ash. (American White. ) Forest tree, tallest of the species, with straight clean trunk, smooth gray bark and glossy leaves.

8-10 ft. - $\$ 1.50$ each; $\$ 12.50$ per 10 . 10-12 ft. $\$ 1.75$ each; $\$ 15.00$ per 10 .

Ash. (European.) Somewhat smaller than the American Ash, with short thick trunk and darker foliage. Remains green in fall.

$8-10 \mathrm{ft} . \$ 2.00$ each; $\$ 17.50$ per 10 . 10-12 ft.— $\$ 2.50$ each; $\$ 22.50$ per 10 .

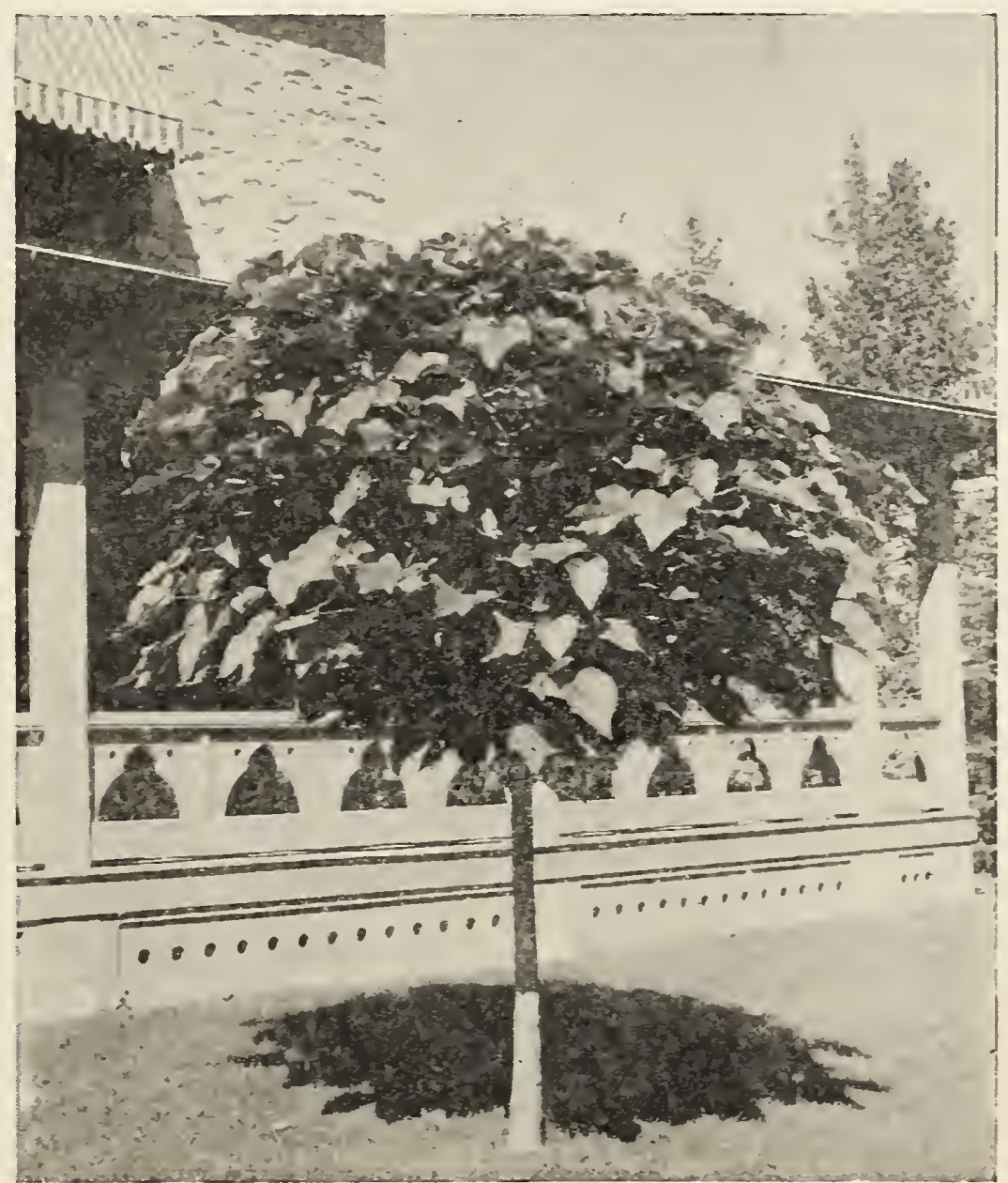




\section{“IT IS NOT A HOME UNTIL IT'S PLANTED"}

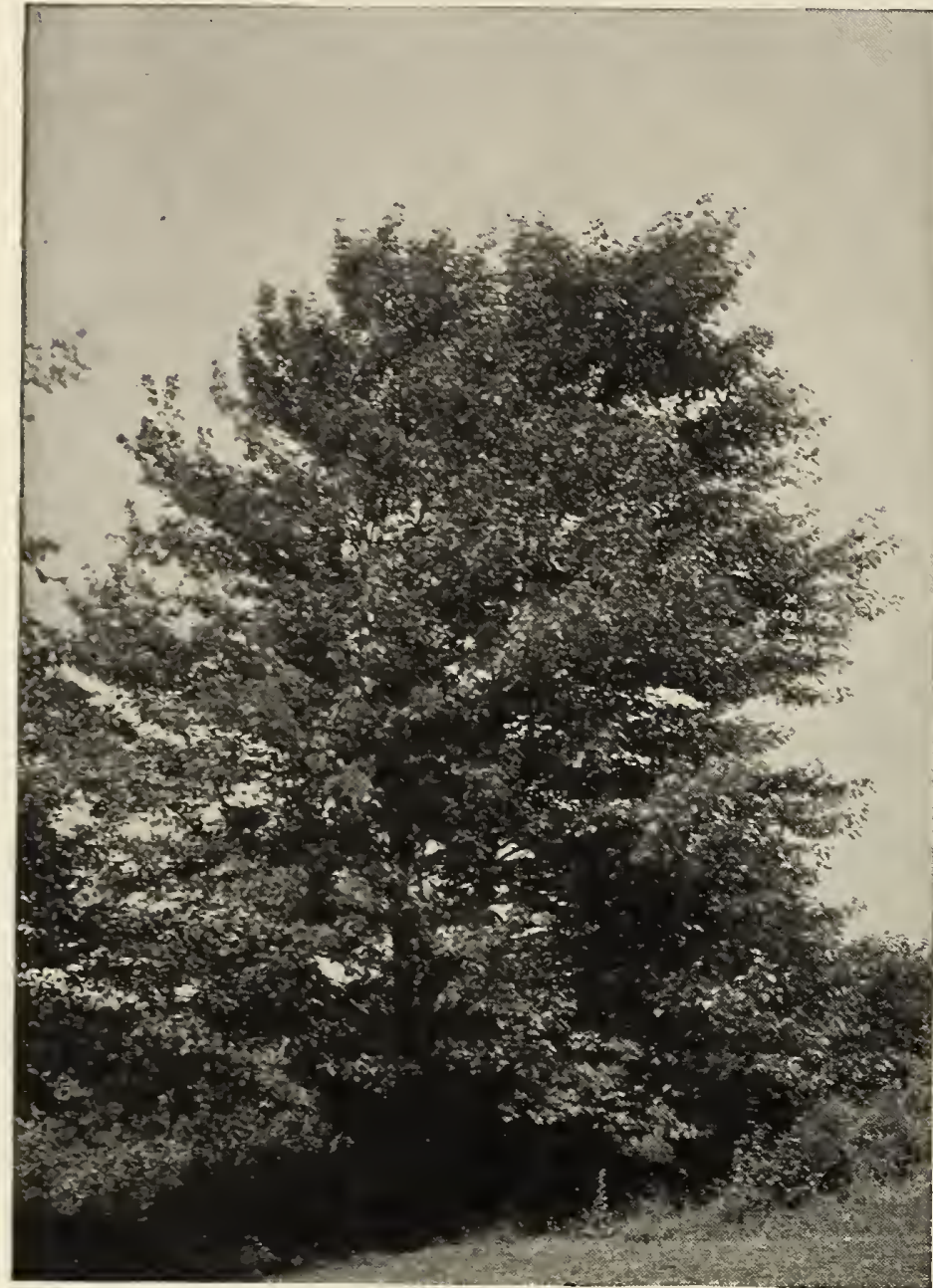

Silver Maple

Almond. (Double Flowered.) A beautiful little tree, which bears a profusion of rose colored blossoms in early spring.

3 to 4 feet- $\$ 1.50$ each; $\$ 12.50$ per 10 .

Birch. (European White.) A vigorous tree, snow white bark, dark green foliage; very graceful and handsome.

8 to 10 feet- $\$ 2.75$ each; $\$ 25.00$ per 10 . 10 to 12 feet-\$3.00 each; $\$ 27.50$ per 10 .

Catalpa Bungeii. (Ủmbrella Cataipa.) Grafted on a stem six to eight feet high, it makes an umbrella shaped top without pruning. Perfectly hardy; flourishes in almost all soils and climates. Leaves large, glossy heart-shaped deep green. A very desirable tree.

\section{Year.}

5 to 6 feet- $\$ 2.50$ each; $\$ 22.50$ per 10 .

6 to 8 feet- $\$ 3.00$ each; $\$ 27.50$ per 10 .

Catalpa Speciosa. A rapid growing tree which is valuable for timber, fence posts, railroad ties, etc. Large, downy, heart-shaped leaves with racemes of white flowers in June, followed by long narrow beans.

8 to 10 feet- $\$ 1.25$ each; $\$ 10.00$ per 10 .

Cornus Florida. (White Flowering Dogwood.) Large white flowers in early spring, young growth bright red.

3 to 4 feet- $\$ 1.25$ each; $\$ 10.00$ per 10 .

Cornus Florida Rubra. Handsome red flowers displayed at even an earlier age than those of the White Dogwood.

3 to 4 feet- $\$ 3.00$ each; $\$ 27.50$ per 10 .
Crab. (Bechtol's Double Flowering.) The tree is sturdy, hardy, and free from disease, of medium size, and when in bloom present the appearance of being covered with delicate pink roses of medium size. Very fragrant.

2 to 3 feet- $\$ 1.25$ each; $\$ 10.00$ per 10 3 to 4 feet- $\$ 1.50$ each; $\$ 12.50$ per 10 .

Elm. (American.) A magnificent, stately tree, wide sweeping top. One of the most noble and graceful trees where a tall, spreading tree is desired.

8 to 10 feet- $\$ 2.00$ each; $\$ 17.50$ per 10 . 10 to 12 feet- $\$ 2.50$ each; $\$ 22.50$ per 10 . $1 \frac{1}{2}-1 \frac{3}{4}$ inches $-\$ 3.00$ each; $\$ 27.50$ per 10 .

Honey Locust. This is a large, vigorous tree with leaves and strong thorns. It makes a handsome and impenetrable hedge. 6 to 8 feet- $\$ 1.50$ each.

Horse Chestnut. (White Flowering.) A beautiful well known tree with dark green foliage, with an abundance of showy white flowers in the early spring.

6 to 8 feet- $\$ 2.50$ each. 8 to 10 feet- $\$ 3.00$ each.

Linden, American. (Basswood. ) A rapid growing tree of large size. Particularly valuable for its beautiful white wood. Large shining leaves and white flowers.

8 to 10 feet- $\$ 2.50$ each.

Linden. (European.) A fine pyramidal tree; leaves exceedingly broad, flowers appear in the month of June.

8 to 10 feet- $\$ 2.50$ each.

Liquidamber. (Sweet Gum.) A stately tree with narrowly ovate head, star-shaped lustrous leaves a dark green and cork bark. Its form is broad and pyramidal, and adapted for streets and avenues; its leaves in the spring emit a refreshing fragrance, and assume a rich crimson-scarlet in the fall. It gets its name from its fragrant sap and leaves.

6 to 8 feet- $\$ 2.50$ each. 8 to 10 feet- $\$ 3.00$ each.

Maple. (Ash-Leaf.) (Box-Elder.) Grows rapidly to a large, spreading tree. It is easily distinguished by its leaves and greenish-yellow bark.

8 to 10 feet- $\$ 1.25$ each; $\$ 10.00$ per 10 . 10 to 12 feet- $\$ 1.50$ each; $\$ 12.50$ per 10 .

Maple. (Norway.) A handsome tree of large and fairly rapid growth, forming a dense rounded head of strong branches, and broad, deep green leaves. The best of the maples, and very desirable for street, lawn or park planting.

10 to 12 feet- $\$ 4.00$ each; $\$ 37.50$ per 10 . $1 \frac{1 / 2}{2}$ to $13 / 4$ in. $\$ 4.50$ each; $\$ 42.50$ per 10 . $1 \frac{3}{4}$ to 2 in. $\$ 5.00$ each; $\$ 47.50$ per 10 . Maple. (Schwedleri.) Very attractive, the foliage is of bright red and purple in the spring, a purplish green in mid-summer and golden yellow in the autumn.

6 to 8 feet- $\$ 3.75$ each; $\$ 35.00$ per 10 .

8 to 10 feet- $\$ 4.50$ each; $\$ 42.50$ per 10 . 10 to 12 feet-\$5.25 each; \$50.00 per 10 .

Maple. (Sugar or Rock.) A native tree, valuable for its production of wood and sugar.

8 to 10 feet- $\$ 2.50$ each; $\$ 22.50$ per 10 . 10 to 12 feet- $\$ 3.00$ each; $\$ 27.50$ per 10 . 
Maple. (Silver.) Hardy, rapidgrowing tree, large, valuable for producing q u i c k shade, good for street planting, foliage bright green $a b$ ove with sil ve ry white beneath. 8 to 10 feet$\$ 1.75$ e a c h ; $\$ 15.00$ per 10 . 10 to 12 feet$\$ 2.25$ e a c h $\$ 20.00$ per 10 . $11 / 2$ to $13 / 4$ inches $-\$ 2.75$ e a c h; $\$ 25.00$ per 10 .

$13 / 4$ to 2 inches $\$ 3.50$ e a c h ; $\$ 32.50$ per 10 .

Maple. (Weir's Cut Leaf.) One of the most remarkable and beautiful trees with cut foliage. $\quad R$ a p id grower, slender and drooping. Foliage a bu nd ant, g r e e $n$ above, silver beneath. 10 to 12 feet- \$3.00 each; $\$ 27.50$ per 10 .

Oak. (Pin.) Almost pyramidal, and sometimes described as half weeping when old, as the lower branches nearly touch the ground. Leaves deep green, glossy and finely divided.

6 to 8 feet- $\$ 2.25$ each; $\$ 20.00$ per 10 .

8 to 10 feet- $\$ 2.50$ each; $\$ 22.50$ per 10 . 10 to 12 feet- $\$ 3.00$ each; $\$ 27.50$ per 10 .

Oak. (Scarlet.) A grand, round-topped tree with bright green deeply cut leaves that color to a sparkling red in the fall.

6 to 8 feet- $\$ 3.00$ each. 8 to 10 feet- $\$ 3.50$ each.

Oriental Plane. (European Sycamore.) Very popular for street planting. A rapid, upright, clean grower, with beautiful dense foliage; attains a large size.

8 to 10 feet- $\$ 2.25$ each; $\$ 20.00$ per 10 . 10 to 12 feet- $\$ 3.00$ each; $\$ 27.50$ per 10 $1 \frac{1 / 2}{33 / 4}$ inch- $\$ 3.75$ each; $\$ 35.00$ per 10 . $13 / 4-2$ inch- $\$ 4.25$ each; $\$ 40.00$ per 10 .

Poplar. (Bolleana.) Rapid growing tree, pyramidal in shape, with leaves deep glossy green above and silvery white beneath.

6 to 8 feet- $\$ 1.50$ each; $\$ 12.50$ per 10 .

8 to 10 feet-\$2.00 each; $\$ 17.50$ per 10 . 10 to 12 feet- $\$ 2.50$ each; $\$ 22.50$ per 10 .

Poplar. (Lombardy.) Symmetrical, pyramidshaped head, glossy leaves. Well known for its erect, rapid growth and commanding form. Very desirable in large grounds.

8 to 10 feet- $\$ 1.00$ each; $\$ 7.50$ per 10 . 10 to 12 feet- $\$ 1.25$ each; $\$ 10.00$ per 10 .

\section{Norway Maple}

Purple Leaf Plum. (Prunus Pissardi.) A handsome little tree covered with small white flowers in spring, after with pinkish purple leaves which deepen in color to the end of the season. Retaining this hue better than most purple-foliaged plants. 4 to 5 feet-\$1.25 each; $\$ 10.00$ per 10 .

Tulip Tree (Whitewood.) One of the most beautiful of our native trees. Upright growing with heavy foliage and bright glossy leaves. Beautiful tulip-like flowers. One of the Magnolia family. It has been one of the most raluable trees in our native forest, producing the highest quality of lumber and it is one of the most beautiful trees that can be grown.

6 to 8 feet- $\$ 1.75$ each.

\section{WEEPING TREES}

The superior grace and beauty of the weeping varieties render them especially adapted to the yard, lawn or cemetery. No collection is complete without them.

Birch. (Cut-Leaved.) One of the most popular of all weeping trees; tall, slender, yet vigorous, graceful drooping habit, silvery white bark and delicately cut foliage.

4 to 5 feet- $\$ 3.00$ each.

5 to 6 feet- $\$ 3.50$ each.

6 to 8 feet- $\$ 4.00$ each.

8 to 10 feet- $\$ 4.50$ each.

Cherry. (Japan Weeping.) An exquisite 
little tree, draped in rosy masses of bloom in early spring before its leaves appear.

1 year $\$ 4.50$ each.

2 years- $\$ 5.00$ each.

Elm. (Camperdown Weeping.) When well grown forms an enclosure twenty or thirty feet in diameter.

1 year - $\$ 3.25$ each.

2 years- $\$ 3.75$ each.

Mulberry. (Tea's Weeping.) One of the most graceful weeping trees, forming an umbrella shaped head, with slender, willowy branches drooping to the ground.

1 year - $\$ 3.25$ each.

2 years- $\$ 3.75$ each.
Willow. (Laurel-Leaved.) Vigorous, spreading upright grower, with shiny, dark green foliage.

8 to 10 feet- $\$ 1.25$ each; $\$ 10.00$ per 10 . 10 to 12 feet- $\$ 1.50$ each; $\$ 12.50$ per 10 .

Willow. (Rosmarinifolia.) Medium grower with very narrow leaves, silvery underneath.

6 to 8 feet- $\$ 1.50$ each; $\$ 12.50$ per 10 .

Willow. (Wisconsin Weeping.) A fine drooping tree. Appropriate for planting on the banks of streams or lakes. Hardy.

6 to 8 feet- $\$ 1.25$ each; $\$ 10.00$ per 10 . 8 to 10 feet- $\$ 1.50$ each; $\$ 12.50$ per 10 .

\section{EVERGREENS}

$\mathbf{H}$

ARDY coniferous evergreens are indispensable in much of the landscape work that is done today. Every lawn, park, etc., should have at least a few of these beautiful specimens to give the bit of color that is needed to set off the rest of the planting. They are especially valuable as backgrounds against which to group other trees and plants with beautiful colored leaves and branches. They are useful for screens and windbreaks, and, besides this, furnish homes for birds that remain with us during the winter.

In foundation plantings they add beauty and distinct charm throughout the entire year. During the summer season their many delightful tints of greens, blues, and yellows create wonderful daily changing effects which dim, if not altogether obscure, all other plantings. In winter there is a grandeur about an Evergreen planting that is superb. On bleak, dark days they lend their touch of color and brighten up the entire home, reflecting happiness and sunshine into one's very soul. On bright, clear, cold days they whisper of springtime and of the many surprises nature is about to unfold.

Arbor Vitae. (American.) The best for evergreen hedge. Grows very rapidly and can be pruned to any shape desired. Makes a dense and beautiful hedge for dividing a lawn, but should not be expected to turn stock. It is also desirable for planting in clumps with other trees. $2 \mathrm{ft}$., $\$ 2.50$ each; $\$ 22.50$ per 10 . $21 / 2$ ft., $\$ 3.00$ each; $\$ 27.50$ per 10 . 3 ft., $\$ 3.50$ each; $\$ 32.50$ per 10 . 4 ft., $\$ 4.50$ each; $\$ 42.50$ per 10 . 5 ft., $\$ 8.50$ each; $\$ 75.00$ per 10 .

Arbor Vitae. (Pyramidalis.) Forms a tall, slender column of dark green. Keeps a fine color all season. Hardy.

\begin{tabular}{|c|c|c|}
\hline & Each & Per 10 \\
\hline 18 & inch $_{----\$ 2.75}$ & $\$ 25.00$ \\
\hline 2 & feet_-- 3.25 & 30.00 \\
\hline $21 / 2$ & feet $_{---} 4.00$ & 37.5 \\
\hline 3 & feet_-- $_{-} 4.75$ & 45.0 \\
\hline & feet_-- 5.50 & \\
\hline & feet_-- 6.25 & \\
\hline
\end{tabular}

Arbor Vitae (Compacta.) Dwarf, rounded, dense; with leaves of light grayish green.

15 inch- $\$ 3.00$ each.

18 inch- $\$ 3.50$ each.

Arbor Vitae. (Geo. Peabody.) P y r a $\mathrm{m}$ i d a l arborvitae with golden foliage, more distinct in early summer; grows twelve to fifteen $\mathrm{ft}$. 12 inch-\$2.00 each.

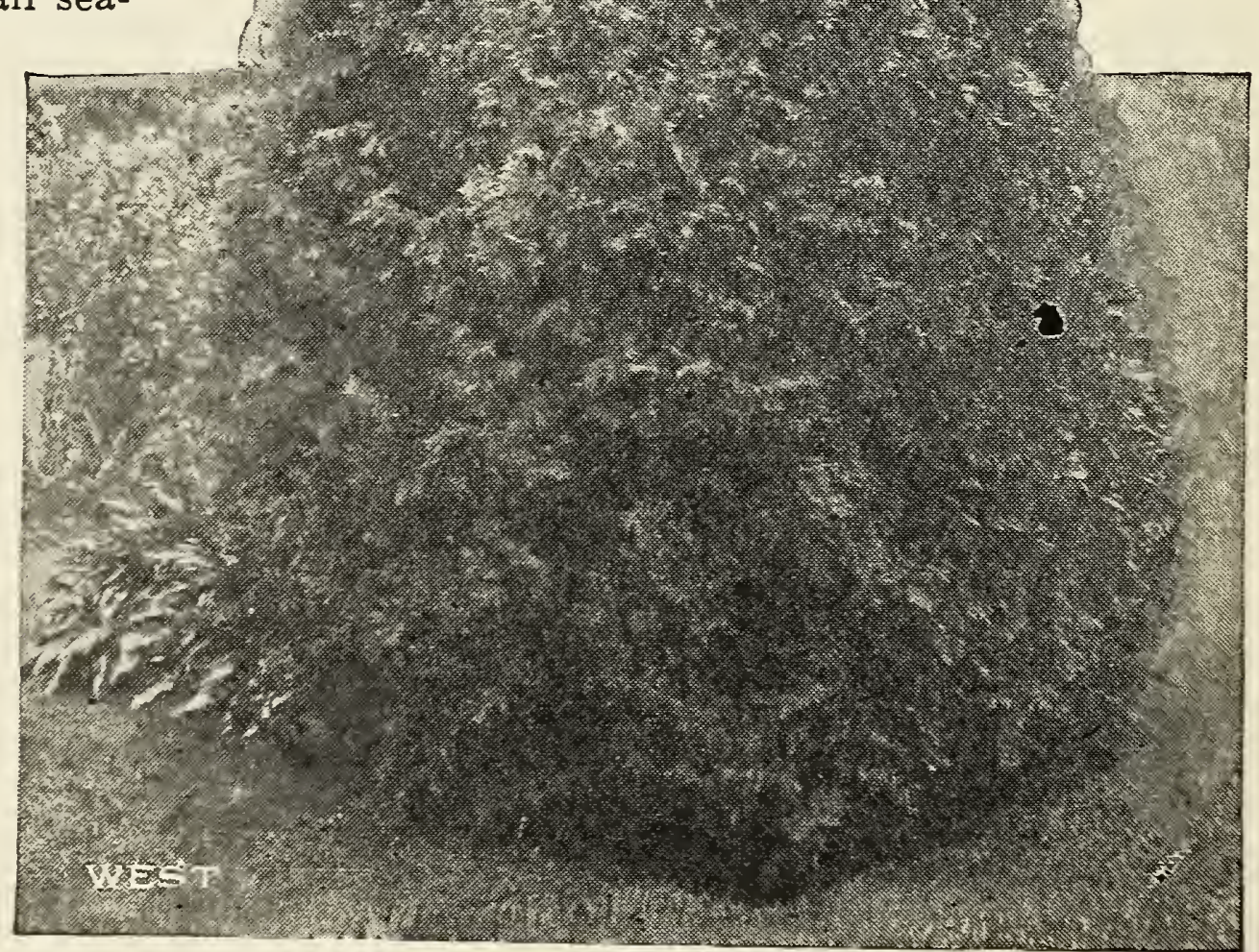

American 
Arbor Vitae. (Hovey's Globosa.) Very dwarf, making a perfect globe; bright green.

12 inch-\$2.00 each.

15 inch- $\$ 3.00$ each.

18 inch-\$3.50 each.

Juniper. (Irish.) An erect, dense column of dark green, found quite effective in general landscape and formal planting.

2 feet- $\$ 3.00$ each.

$21 / 2$ feet- $\$ 3.50$ each.

3 feet- $\$ 4.25$ each.

4 feet- $\$ 5.00$ each.

Juniper. (Pfitzeriana.) The best of all Junipers. Spreading, graceful; branches horizontal, often forming a flat, spreading cap. Blue green foliage.

18 inch- $\$ 3.50$ each.

2 feet- $\$ 4.25$ each.

$21 / 2$ feet- $\$ 5.00$ each.

3 feet- $\$ 6.50$ each.

$31 / 2$ feet- $\$ 7.75$ each.

4 feet- $\$ 8.50$ each.

Juniper. (Swedish.) Of narrow, columnar form, with lighter, more bluish foliage than the Irish Juniper. Branches droop at the tips.

2 feet- $\$ 3.25$ each.

$21 / 2$ feet- $\$ 3.75$ each.

3 feet- $\$ 4.25$ each.

Pine. (Austrian.) A remarkably robust, hardy, spreading tree of grand size, very dark and massive in effect.

2 feet- $\$ 3.75$ each.

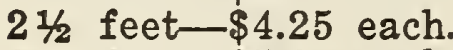

3 feet- $\$ 5.00$ each.

Pine. (Scotch.) Dense, broadly pyramidal, luxuriant in growth, with strong erect shoots and silvery needles.

2 feet- $\$ 3.50$ each.

$21 / 2$ feet- $\$ 4.00$ each.

3 feet- $\$ 4.50$ each.

Pine. (White.) Tall and stately, one of the quickest growing and longest lived. The needles are long and silvery blue.

3 feet- $\$ 4.50$ each.

4 feet- $\$ 5.25$ each.

5 feet- $\$ 6.50$ each.

Retinspora. (Pisifera.) A bushy, rapid grower, with slender branches and light green leaves.

18 inch-\$3.50 each.

2 feet- $\$ 4.25$ each.

$21 / 2$ feet- $\$ 5.00$ each.

3 feet- $\$ 6.00$ each.

3 1/2 feet- $\$ 7.00$ each.

4 feet- $\$ 8.00$ each.
Retinspora. (Pisifera Aurea.) A bright golden evergreen, that holds its color; foliage light and airy. Fine for groups or specimens.

18 inch- $\$ 3.50$ each.

2 feet- $\$ 4.25$ each.

$21 / 2$ feet- $\$ 5.00$ each.

3 feet- $\$ 6.00$ each.

$31 / 2$ feet- $\$ 7.00$ each.

4 feet- $\$ 8.00$ each.

Spruce. (Black Hills.) The hardiest of all Spruces, symmetrical, compact and bushy in habit of growth. The foliage varies from green to bluish tint, and the trees are remarkable for their bright fresh color.

2 feet- $\$ 2.75$ each.

$21 / 2$ feet- $\$ 3.25$ each.

3 feet- $\$ 4.00$ each.

Spruce. (Hemlock.) Beautiful native evergreen. Free and drooping in growth, but dense when pruned, forming good specimen trees, hedges or shelters. Its dark green color is retained all winter. Grows naturally to a large tree.

$\begin{array}{lll}18 & \text { inch- } \$ 3.00 & \text { each. } \\ 2 & \text { feet- } \$ 3.50 & \text { each. } \\ 21 / 2 & \text { feet- } \$ 3.75 & \text { each. } \\ 3 & \text { feet- } \$ 4.25 \text { each. } \\ 31 / 2 & \text { feet- } \$ 5.00 & \text { each. } \\ 4 & \text { feet- } \$ 6.50 \text { each. }\end{array}$

Spruce. (Colorado Blue.) A magnificent tree with foliage of a silvery blue. Hardy and vigorous.

2 feet-\$ 7.50 each.

$21 / 2$ feet- $\$ 10.00$ each.

3 feet- $\$ 12.50$ each.

Spruce. (Colorado Green.) With brilliant foliage. Hardy in any exposure and of vigorous growth.

2 feet- $\$ 3.75$ each.

$21 / 2$ feet- $\$ 5.00$ each.

3 feet- $\$ 6.25$ each.

Spruce. (Norway.) The most universally planted evergreen, for screens, hedges, windbreaks and back-grounds. Perfectly hardy and easily transplanted.

18 inch-\$2.00 each; \$17.50 per 10.

2 feet- $\$ 2.50$ each; $\$ 22.50$ per 10 .

$21 / 2$ feet- $\$ 3.00$ each; $\$ 27.50$ per 10 .

3 feet-\$3.75 each; $\$ 35.00$ per 10 .

4 feet-\$4.25 each; $\$ 40.00$ per 10 .

5 feet- $\$ 6.00$ each; $\$ 57.50$ per 10 .

6 feet- $\$ 8.50$ each; $\$ 80.00$ per 10 . 


\section{HEDGE PLANTS}

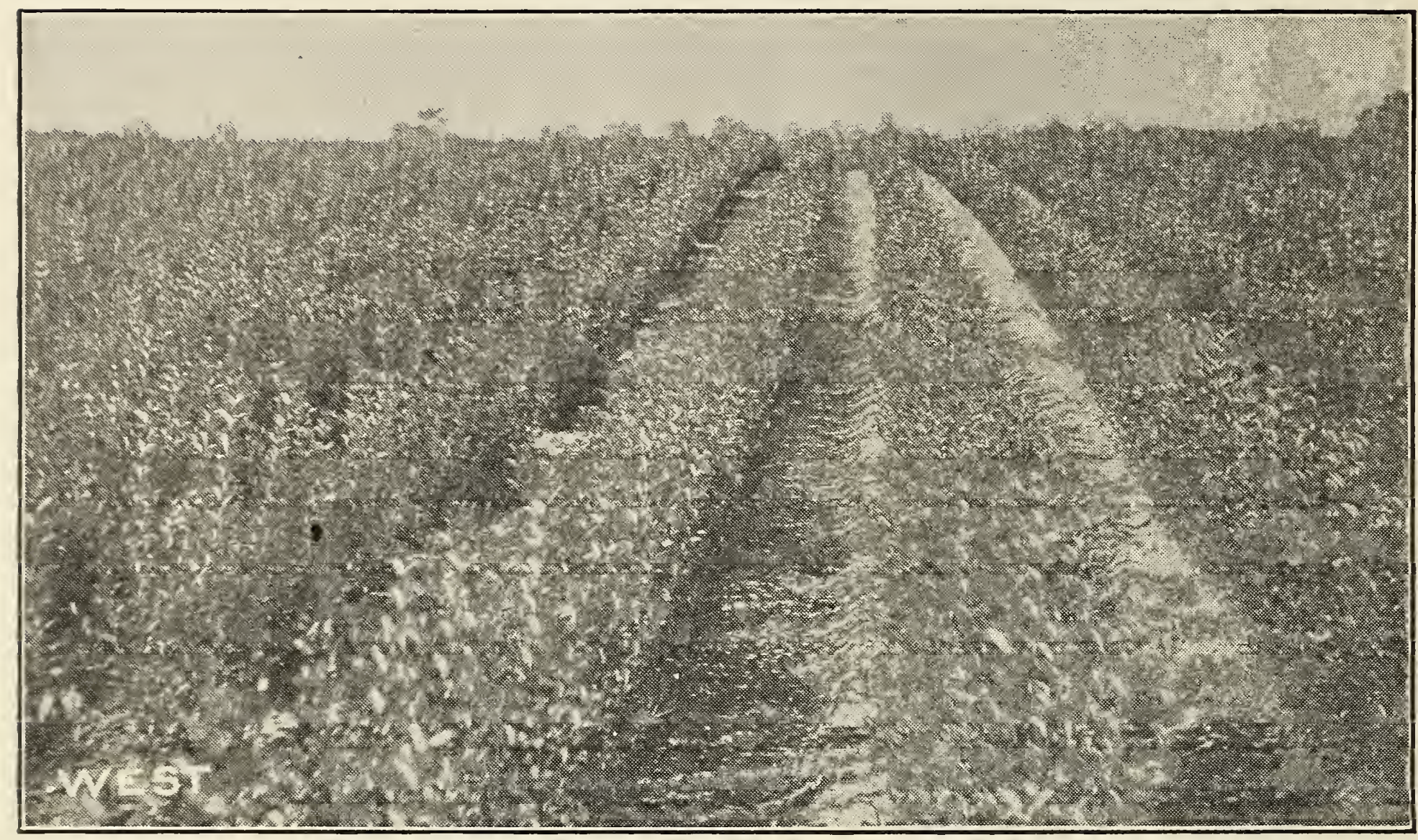

\section{A Block of California Privet}

$\mathbf{F}$

ENCES are all right to keep the cows out of the corn, but they are distinctly out of place on the home grounds. What you want between your grounds and those of your neighbor is a hedge of Privet or Spirea. Not only does the hedge look better than a fence but it is permanent. A fence rots or rusts away, and after a few years must be replaced. A hedge remains year after year, and increases in value and beauty each succeeding year. It will grow dense clear to the ground and make a tight barrier to all animals.

For quick reference we designate such plants as are used for hedging purposes. These plants have been several times transplanted and are suitable for immediate planting.

Arbor Vitae. (American.) See Evergreens.

\section{Barberry Thunbergi. Yellow flowers} followed by scarlet berries which hang on through the winter; the green foliage changing to scarlet and gold in the fall. Makes a beautiful hedge.

15 to 18 in.- $\$ 2.50$ per $10 ; \$ 20.00$ per 100. 18 to 24 in. $-\$ 3.50$ per 10 ! $\$ 30.00$ per 100.2 to 3 feet- $\$ 4.50$ per $10 ; \$ 40.00$ per 100 .

Privet. (Amoor River North.) A very hardy northern grown type, vigorously upright and tall growing. The leaves are dark green but not so persistent as those of the California Privet.

2 to 3 feet- $\$ 2.00$ per $10 ; \$ 16.00$ per 100 . 3 to 4 feet- $\$ 2.50$ per $10 ; \$ 20.00$ per 100 .
Privet. (California. ) Thick, glossy rich, green leaves. Can be trimmed to any shape. Hardy.

$15-18$ in. -60 cts. per $10 ; \$ 5.00$ per 100 $18-24$ in. -80 cts. per $10 ; \$ 6.00$ per 100 .

Privet. (Ibota.) A fine, hardy border shrub, of spreading habit, growing 8 to 12 feet tall, with curving branches and leaves of grayish green. Its pure white flowers appear in June, to be followed later by bluishblack seeds, which persist until winter. $15-18$ in. $\$ 2.00$ per $10 ; \$ 18.00$ per 100 . $18-24$ in.-\$2.50 per $10 ; \$ 20.00$ per 100 .

Privet. (Lodense.) A slow growing densely compact dwarf bush, which can be used without shearing, for very low hedges and borders. It can be planted close and kept clipped down like Boxwood.

$9-12$ in. $-\$ 2.00$ per $10 ; \$ 16.00$ per 100 . $12-15$ in.-\$2.50 per $10 ; \$ 20.00$ per 100 .

Privet. (Vulgaris.) (English.)

$15-18$ in. $\$ 2.00$ per $10 ; \$ 18.00$ per 100 .

$18-24$ in.-\$2.50 per $10 ; \$ 20.00$ per 100 .

Spirea Van Houtte. See Shrubs.

Spruce. (Norway.) See Evergreens. 


\section{DECIDUOUS SHRUBS}

$\mathbf{I}$ CORNERS of the grounds, at curves in the walk and driveways, and at the house foundation are excellent places to plant shrubs. They should be in groups, unless their ultimate size will be quite large. Lilacs may be used in specimen plantings, but low-growing shrubs, such as Barberry, the Spirea, etc., should be set in clumps. In growing it is always good policy to plant the taller growing varieties back of the lower sorts. This gives a "stepdown" effect and seems to join the house to the lawn.

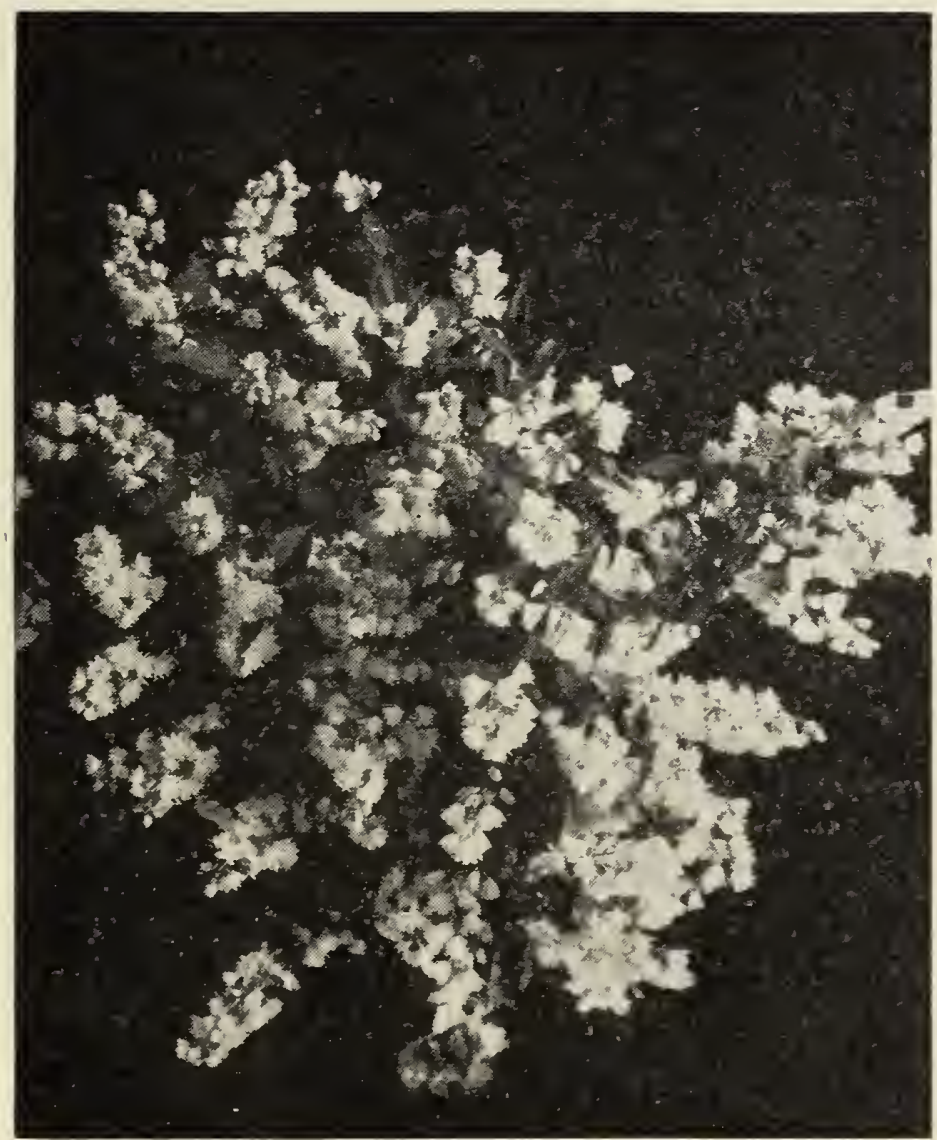

Deutzia Crenata (Fl. Pl.)

ALTHEA. (Rose of Sharon.) Blooms late in August and September, with large brightly colored flowers. When planted compactly and pruned they make a serviceable and showy hedge. Colors: Double Rose, Double Variegated, Double White, Double Purple and Variegated Leaf.

2 to 3 feet -60 cts. each; $\$ 5.00$ per 10 . 3 to 4 feet-75 cts. each; $\$ 6.50$ per 10

CALYCANTHUS. (Sweet Shrub.) Having a rare peculiar fragrance of wood and flowers. Blossoms of a chocolate red color. 2 to 3 feet-75 cts. each; $\$ 6.50$ per 10 .

CLETHRA ALNIFOLIA. (Sweet Pepper Bush.) Fragrant wands of white flowers in September.

18 to 24 in. -60 cts. each; $\$ 5.00$ per 10 . 2 to 3 feet-70 cts. each; $\$ 6.00$ per 10 .

CORNUS. (Elegantissima Variegata.) Dark green foliage margined with silver and red; wood a dark purplish red.

2 to 3 feet -80 cts. each; $\$ 7.00$ per 10 . 3 to 4 feet-90 cts. each; $\$ 8.00$ per 10 .

Paniculata. Medium sized bush with finely branched stems; creamy white flowers, followed with clusters of pearly white berries in August and September.

2 to 3 feet -60 cts. each; $\$ 5.00$ per 10 .

Siberica. Bright red bark in winter; clusters of small white flowers in early summer. 2 to 3 feet-50 cts. each; $\$ 4.00$ per 10 . 3 to 4 feet-60 cts. each; $\$ 5.00$ per 10 .
Stolonifera. Large spreading shrub of rapid growth with dull red branches in winter and round, white fruit.

3 to 4 feet -70 cts. each; $\$ 6.00$ per 10 .

4 to 5 feet -80 cts. each; $\$ 7.00$ per 10 .

Stolonifera Lutea. A striking yellow-branched form of Stolonifera, very satisfactory for contrasting.

$2-3$ feet-60 cts, each; $\$ 5.00$ per 10 . 3-4 feet-75 cts. each; $\$ 6.50$ per 10 .

CYDONIA. (Japan Quince.) Hardy shrub, double crimson flowers in early spring. 2 to 3 feet- $\$ 1.00$ each

DEUTZIA. They vary greatly in height and habit, but all have dainty bell or tassleshaped flowers borne thickly in wreaths along their branches in June.

Crenata. Beautiful white single flowered species, growing 6 to 8 feet tall.

2 to 3 feet-50 cts. each; $\$ 4.00$ per 10 . 3 to 4 feet -60 cts. each; $\$ 5.00$ per 10 .

Gracilis. A dense little bush rarely over two feet high, that blooms in May. Pure white flowers.

15 to 18 in. -50 cts. each; $\$ 4.00$ per 10 . 18 to 24 in. -60 cts. each; $\$ 5.00$ per 10

Lemoinei. Rarely growing over three feet high, with spreading branches, bright green leaves, white flowers in large clusters. 2 to 3 feet -80 cts. each; $\$ 7.00$ per 10 .

Pride of Rochester. This variety grows six to eight feet tall. The white flowers are large and double.

2 to 3 feet-50 cts. each; $\$ 4.00$ per 10 . 3 to 4 feet -60 cts. each; $\$ 5.00$ per 10 .

Rosea. Rose colored flowers. 2 to 3 feet -50 cts. each; $\$ 4.00$ per 10 . 3 to 4 feet-60 cts. each; $\$ 5.00$ per 10 .

ELDER. (Cut Leaf.) Fragrant white flowers in June and July, followed by large clusters of fruit.

2 to 3 feet-60 cts. each; $\$ 5.00$ per 10 . 3 to 4 feet-70 cts. each; $\$ 6.00$ per 10 .

ELDER. (Golden.) Handsome with golden yellow leaves, valuable for enlivening shrubbery. Can be pruned into a neat, compact little bush, or grows naturally from ten to fifteen feet high.

2 to 3 feet -60 cts. each; $\$ 5.00$ per 10 . 3 to 4 feet-70 cts. each; $\$ 6.00$ per 10 .

FORSYTHIA. (Golden Bell.) Masses of yellow bell-shaped flowers in the early spring before the leaves appear. Perfectly hardy. 2 to 3 feet-50 cts. each; $\$ 4.00$ per 10 . 3 to 4 feet -60 cts. each; $\$ 5.00$ per 10 .

Fortunei. Strong growing, erect branches.

Intermedia. Blooms very early. Slender, arching branches.

Suspensa. Long, curving branches used for covering arches and trellises.

HONEYSUCKLE-

2 to 3 feet-50 cts. each; $\$ 4.00$ per 10 . 3 to 4 feet-60 cts. each; $\$ 5.00$ per 10 . 


\section{HONEYSUCKLE-}

Tartarian. Pink, red or white flowers, followed by red or orange berries.

Bella Albida. About six feet tall, with clusters of fragrant white flowers, followed by bright red berries, which cling all summer. Very hand some.

Bella Rosea. Similar to the Albida, but with rose colored flowers.

Morrowi. Grows only about four to five feet tall, spreading. Pure white flowers in early spring, with brilliant red fruits in August, which are persistent through the fall.

Morrowi Red. Similar to the above but with red flowers.

Xylosteum. Yellow flowers in May followed by Red Berries which persist during most of the summer.

\section{HYDRANGEA-}

18-24 inches-60 cts. each; $\$ 5.00$ per 10 .

2 to 3 feet-70 cts, each; $\$ 6.00$ per 10 .

Arborescens. Large white flowers in July and August, which resemble a Snowball.

Paniculata Grandiflora. Massive plumes of white flowers which change to pink and bronze green. Perfectly hardy. One of the most effective shrubs.

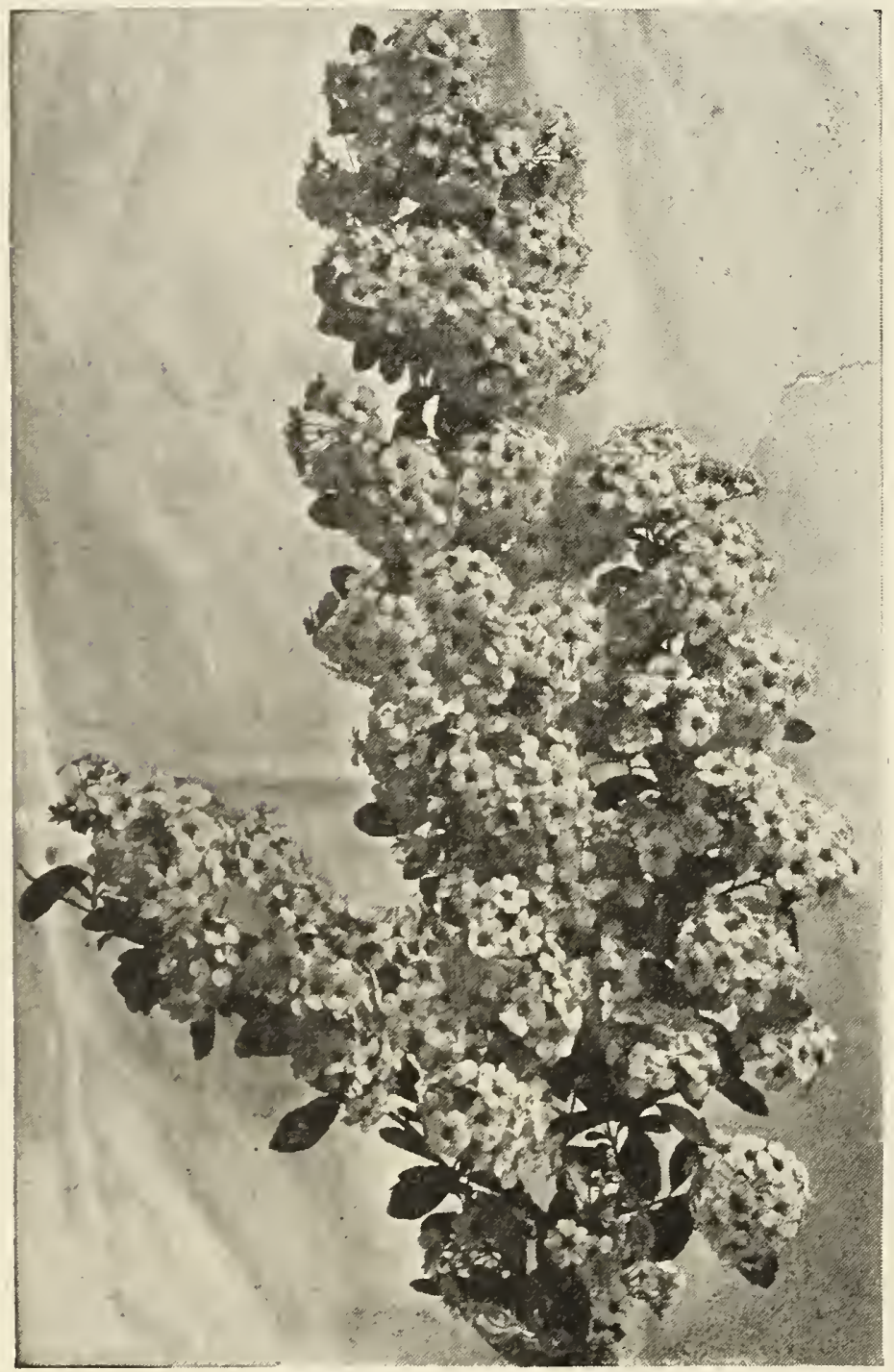

Spirea Van Houtte

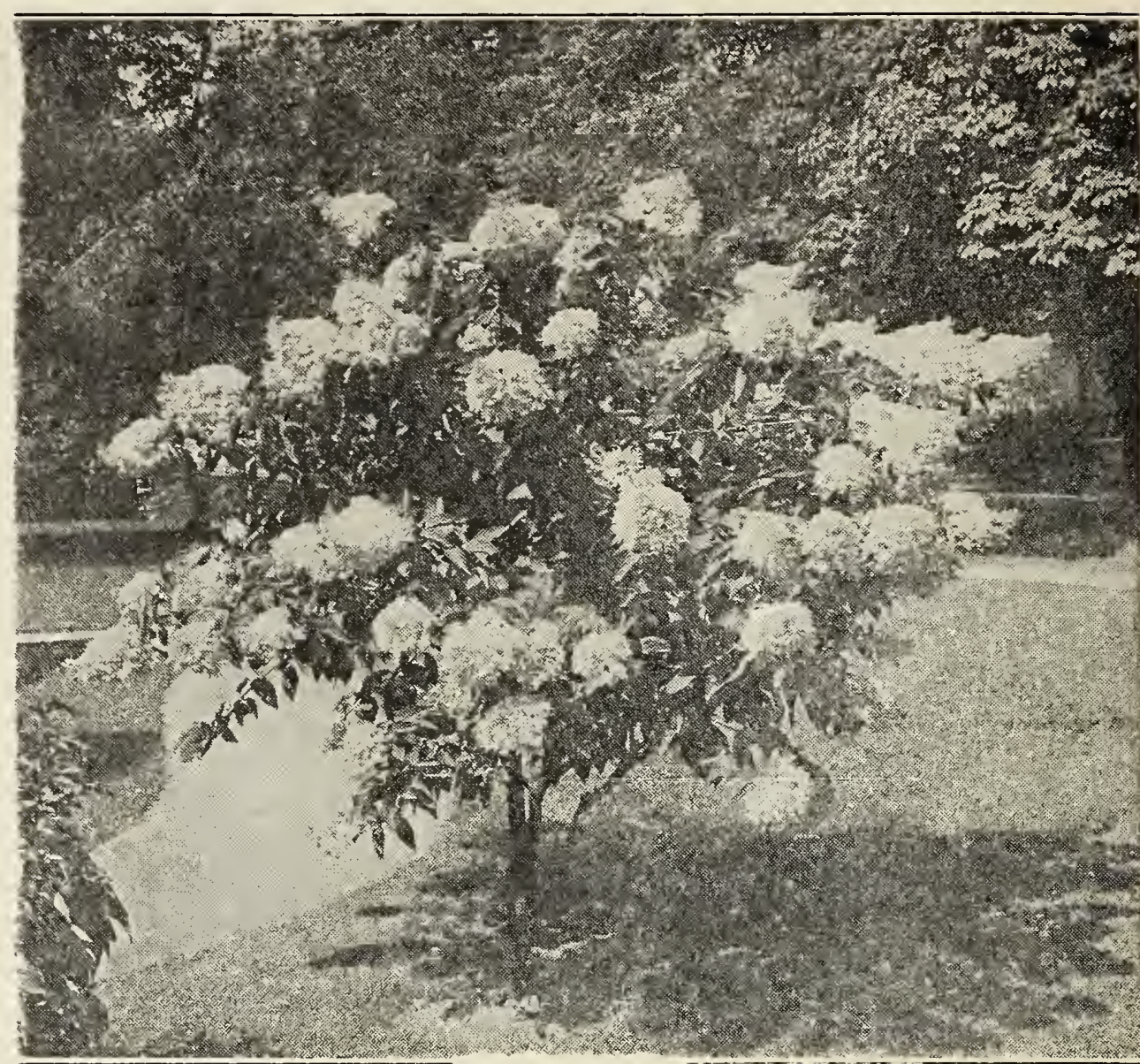

\section{Hydrangea}

Paniculata Grandiflora. Tree shape. 3 to 4 feet- $\$ 1.25$ each.

LILAC. Common Purple. Old-fashioned sweet-scented lilac of our childhood. Their fragrance should bless every home.

2 to 3 feet -50 cts each; $\$ 4.00$ per 10 .

3 to 4 feet -60 cts. each; $\$ 5.00$ per 10 .

Purple Grafted.

2 to 3 feet- $\$ 1.00$ each; $\$ 9.00$ per 10 .

Alphonse Lavelle. Violet blue.

Ludwig Spaeth. Dark blue.

Belle de Nancy. Satiny rose with white center.

LaTour d'Auvergne. Dark double red.

Mad. A. Chateney. Snow white.

Monument Carnot. Pale lilac.

Persian. Purple and white, dwarf growing.

Pres. Grevy. Double blue.

Villosa. Dwarf, broad-leaved, lt. pink flowers. 2 to 3 feet -75 cts. each; $\$ 6.50$ per 10 .

PHILADELPHUS (Aurea.) A medium sized shrub with golden foliage that remains bright through the season. Valuable for contrastive planting.

15 to 18 inches-75 cts. each; $\$ 6.50$ per 10 . 18 to 24 inches-85 cts. each; $\$ 7.50$ per 10 .

Coronarius. (Garland Syringa.) Early bloomer, its large white flowers in graceful sprays are delightfully scented.

2 to 3 feet -50 cts. each; $\$ 4.00$ per 10 .

3 to 4 feet-60 cts. each; $\$ 5.00$ per 10 .

Gordonianus. Strong growing; large white flowers late in July.

2 to 3 feet -50 cts. each; $\$ 4.00$ per 10 .

3 to 4 feet-60 cts. each; $\$ 5.00$ per 10 .

Grandiflorus. Vigorous: its long irregular branches are clustered with large slightly fragrant flowers in June.

2 to 3 feet -50 cts. each; $\$ 4.00$ per 10 . 3 to 4 feet -60 cts. each; $\$ 5.00$ per 10 .

Virginalis. A magnificent new variety. Moderately tall, with good foliage and compact 


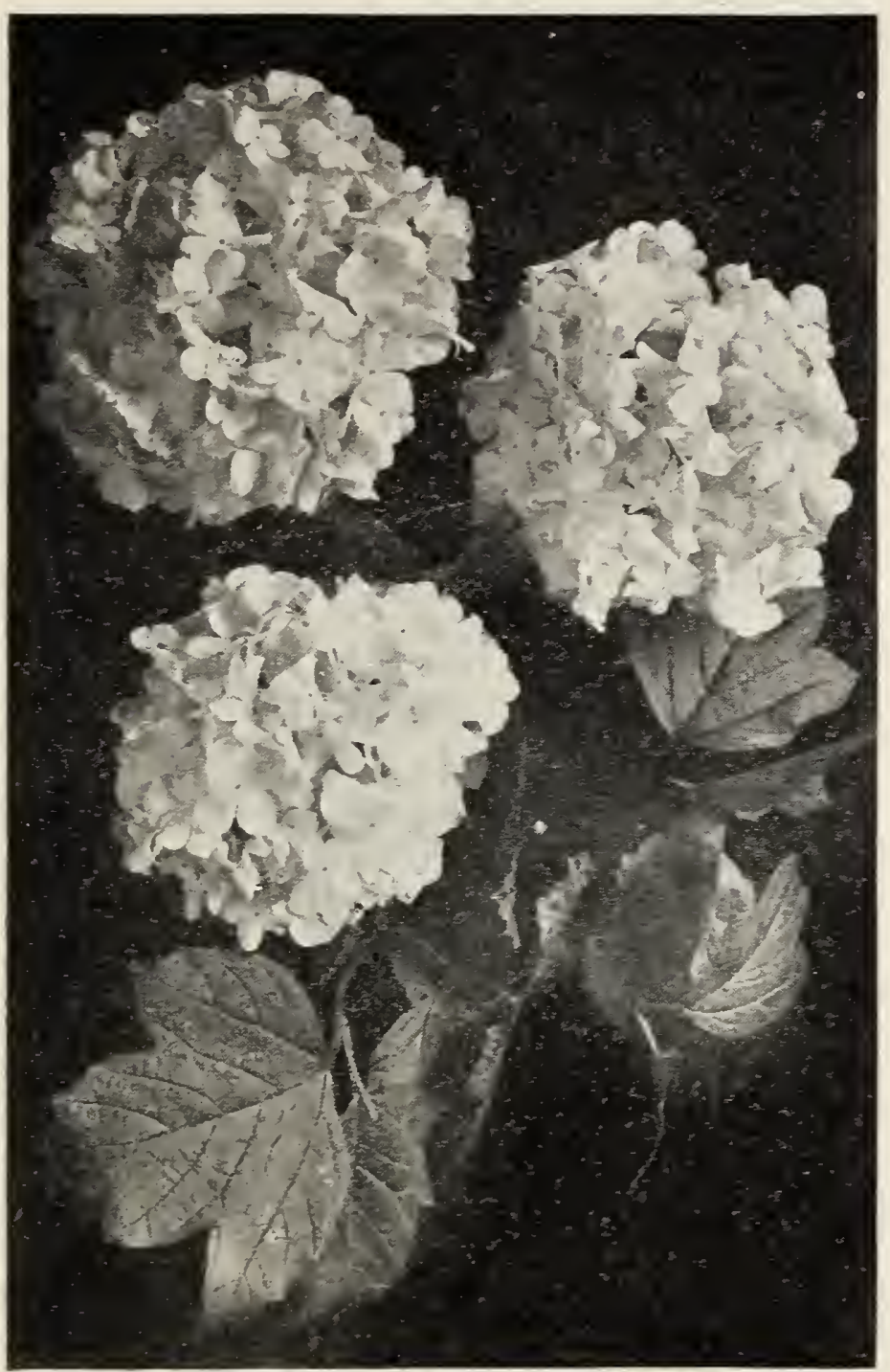

Viburnum (Old Fashoined Snowball)

habit. The flowers are the largest, handsomest, and most sweetly fragrant of any known variety, with longest blooming season.

18 to 24 inch -50 cts. each; $\$ 4.00$ per 10 .

2 to 3 feet -75 cts. each; $\$ 6.50$ per 10.

SPIREA. (Anthony Waterer.) Makes a low compact bush, covered nearly the whole season with bunches of small deep crimson flowers.

15 to 18 inch-50 cts. each; $\$ 4.00$ per 10. 18 to 24 inch-60 cts. each; $\$ 5.00$ per 10 .

Arguta. A slender, upright shrub, 3 to 5 feet high, with branches a snowy mass of clear white flowers in early May.

18 to $24 \mathrm{inch}-60 \mathrm{cts}$. each; $\$ 5.00$ per 10 .

2 to 3 feet-70 cts. each; $\$ 6.00$ per 10 .

Aurea. Leaves bright yellow in spring, gradually changing to golden bronze in fall. Clusters of white flowers in June.

2 to 3 feet-50 cts. each; $\$ 4.00$ per 10 .

3 to 4 feet-60 cts. each; $\$ 5.00$ per 10 .

Billardi. A narrow dense shrub six feet in height, with dense panicles of rich pink flowers in July and August.

2 to 3 feet-50 cts. each; $\$ 4.00$ per 10 . 3 to 4 feet-60 cts. each; $\$ 5.00$ per 10.

Bumalda. A spreading low bush about two feet high with dark leaves brightened by clusters of light pink flowers in May.

15 to 18 inch-50 cts. each; $\$ 4.00$ per 10 . 18 to 24 inch-60 cts. each; $\$ 5.00$ per 10 .

Callosa Alba. Of compact growth four feet high with upright branches and bluish foliage, crowded with large, flat clusters of white flowers nearly all summer.

15 to 18 inch-60 cts. each; $\$ 5.00$ per 10 . 18 to 24 inch-70 cts. each; $\$ 6.00$ per 10.

Douglasi. Upright in growth to about five feet. Bears spikes of deep rose colored flowers in July and August.

2 to 3 feet-50 cts. each; $\$ 4.00$ per 10 .

3 to 4 feet-60 cts. each; $\$ 5.00$ per 10 .

Opuliflora. Very strong growth, clusters of white flowers in June.

2 to 3 feet-50 cts. each; $\$ 4.00$ per 10.

3 to 4 feet-60 cts. each; $\$ 5.00$ per 10 .

Prunifolia. (Bridal Wreath.) Very early bloomer. Its graceful branches are covered nearly their whole length with small double white flowers.

2 to 3 feet-75 cts. each; $\$ 6.50$ per 10 .

Reevesiana. Narrow, pointed leaves, and round clusters of white flowers in June.

2 to 3 feet -50 cts. each; $\$ 4.00$ per 10 . 3 to 4 feet-60 cts. each; $\$ 5.00$ per 10 .

Thunbergi. Dense feathery foliage changing to bright red and orange in fall. Flowers pure white.

18 to 24 inch-60 cts. each; $\$ 5.00$ per 10 .

2 to 3 feet-70 cts. each; $\$ 6.00$ per 10 .

Van Houtte. Is covered in May with small white flowers in clusters, presenting a beautiful appearance. It is very hardy and one of the finest shrubs in cultivation.

2 to 3 feet-50 cts. each; $\$ 4.00$ per 10 . 3 to 4 feet-60 cts. each; $\$ 5.00$ per 10 .

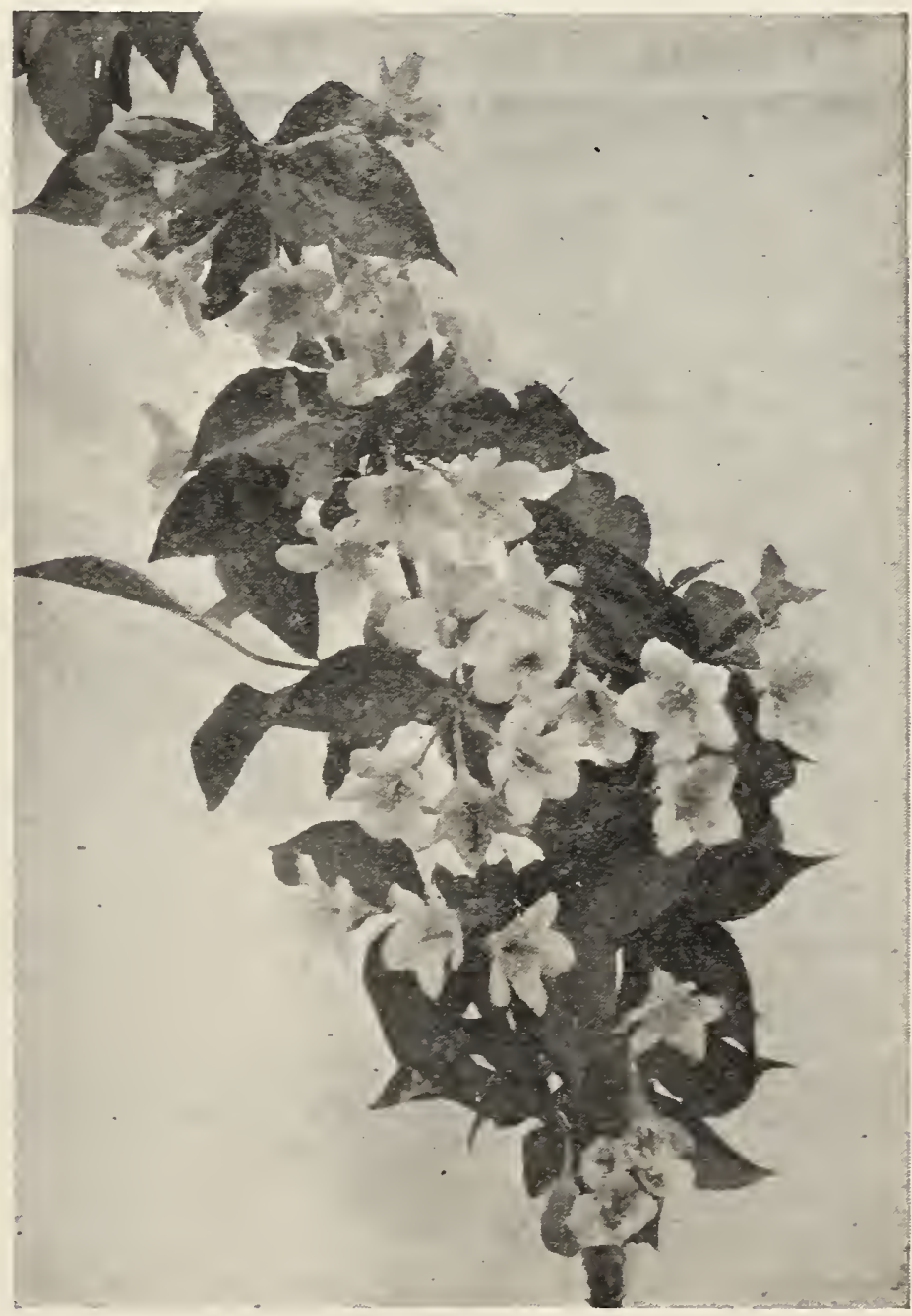

Weigelia 
SYMPHORICARPOS - Racemosus. (Snowberry.) Flowers are inconspicuous, rosecolored, in June and July; leaves thin, dark, green; fruits large, milk-white, clustered, persistent until late in the winter. 2 to 3 feet-60 cts. each; $\$ 5.00$ per 10 . 3 to 4 feet -70 cts. each; $\$ 6.00$ per 10 .

Vulgaris. (Indian Currant or Coral Berry.) Similar to the Snowberry, except that the fruit is red and clusters about the stem in thick ropes. 2 to 3 feet- 50 cts. each; $\$ 4.00$ per 10 .

VIBURNUM - Dentatum. Bright green, heart-shaped leaves turning to purple and red. May and June flowers of creamy white. 18 to 24 inch-50 cts. each; $\$ 4.00$ per 10 . 2 to 3 feet-60 cts. each; $\$ 5.00$ per 10 .

Opulus. (High Bush Cranberry.) Grows from eight to ten feet high, with white flowers in May, followed by beautiful showy clusters of scarlet fruits. 2 to 3 feet -80 cts. each; $\$ 7.00$ per 10 .

Plicatum. Vigorous, upright grower, with deep green foliage and white balls of bloom in June.

18 to 24 inch-75 cts. each; $\$ 6.50$ per 10 . 2 to 3 feet -85 cts. each; $\$ 7.50$ per 10 .

Sterile. (Common Snowball.) Great clusters of white flowers in May.
2 to 3 feet -70 cts. each; $\$ 6.00$ per 10 .

Tomentosum. Dark, heavily veined leaves, panicles of flat, white flowers, followed by red fruit, changing to bluish black.

18 to 24 inch-60 cts. each; $\$ 5.00$ per 10 . 2 to 3 feet-70 cts. each; $\$ 6.00$ per 10 .

WEIGELIA-Abel Carrier. Flowers are rosecarmine with yellow spot in the throat. 2 to 3 feet-60 cts. each; $\$ 5.00$ per 10 . 3 to 4 feet -70 cts. each; $\$ 6.00$ per 10 .

Candida. Vigorous habit and an erect grower. Flowers of pure white and produced in great profusion in June, and continuing during the summer.

2 to 3 feet- 65 cts. each; $\$ 5.50$ per 10 . 3 to 4 feet-75 cts. each; $\$ 6.50$ per 10 .

Eva Rathke. Flowers of a dark carmine red in early summer. One of the best.

2 to 3 feet- $\$ 1.00$ each; $\$ 9.00$ per 10 .

Rosea. Rose colored blossoms in July.

2 to 3 feet -60 cts. each; $\$ 5.00$ per 10 .

3 to 4 feet-70 cts. each; $\$ 6.00$ per 10 .

Van Houtte. Flowers flat, broad, deep rosy red, with orange markings.

2 to 3 feet -60 cts. each; $\$ 5.00$ per 10 . 3 to 4 feet-70 cts. each; $\$ 6.00$ per 10.

Variegata. Leaves are broadly margined with creamy white, pink flowers.

2 to 3 feet-70 cts. each; $\$ 6.00$ per 10.

\section{ROSES}

Roses thrive best in a medium light clay soil. Before planting prepare the soil by spading thoroughly and working over to a depth of about 18 inches, fill in well rotted stable manure while spading and work it carefully into the soil. After the plants are set, for besi results cut all branches back to within 3 to 4 inches of the top of the ground. The new growth coming out will make a much nicer head than if the plant were not pruned, and the bushes will bloom better.

\section{HYBRID PERPETUAL ROSES}

These are the most reliable Bush Roses for the north, flowering profusely in June and most varieties sparingly during the balance of the season. Plants are hardier and flowers ayerage larger than the hybrid teas and are produced mostly on long stems, making them especially desirable for cutting. Do best if planted where they can have good culture and plenty of sunlight.

\section{All Varieties 2 Years,}

\section{Cts. Each; $\$ 7.00$ per 10}

Anna De Diesbach. Bright rose color, very large and showy.

Baron de Bonstettin. A handsome, dark, rich, velvety red rose, blooms very freely.

Clio. Blush white, a very free bloomer and healthy grower. One of the most desiraable.

Eugene Furst. Velvety crimson shaded with darker crimson; very showy and a free bloomer.

Frau Karl Druschki. The best perpetual white rose grown; pure waxy white, large, perfect form, a clean vigorous grower.

General Jacquimenot. A rich crimson scarlet. Simply a mass of bloom when at its best.

Harrison's Yellow. Free blooming, semi-double yellow rose. Very hardy.

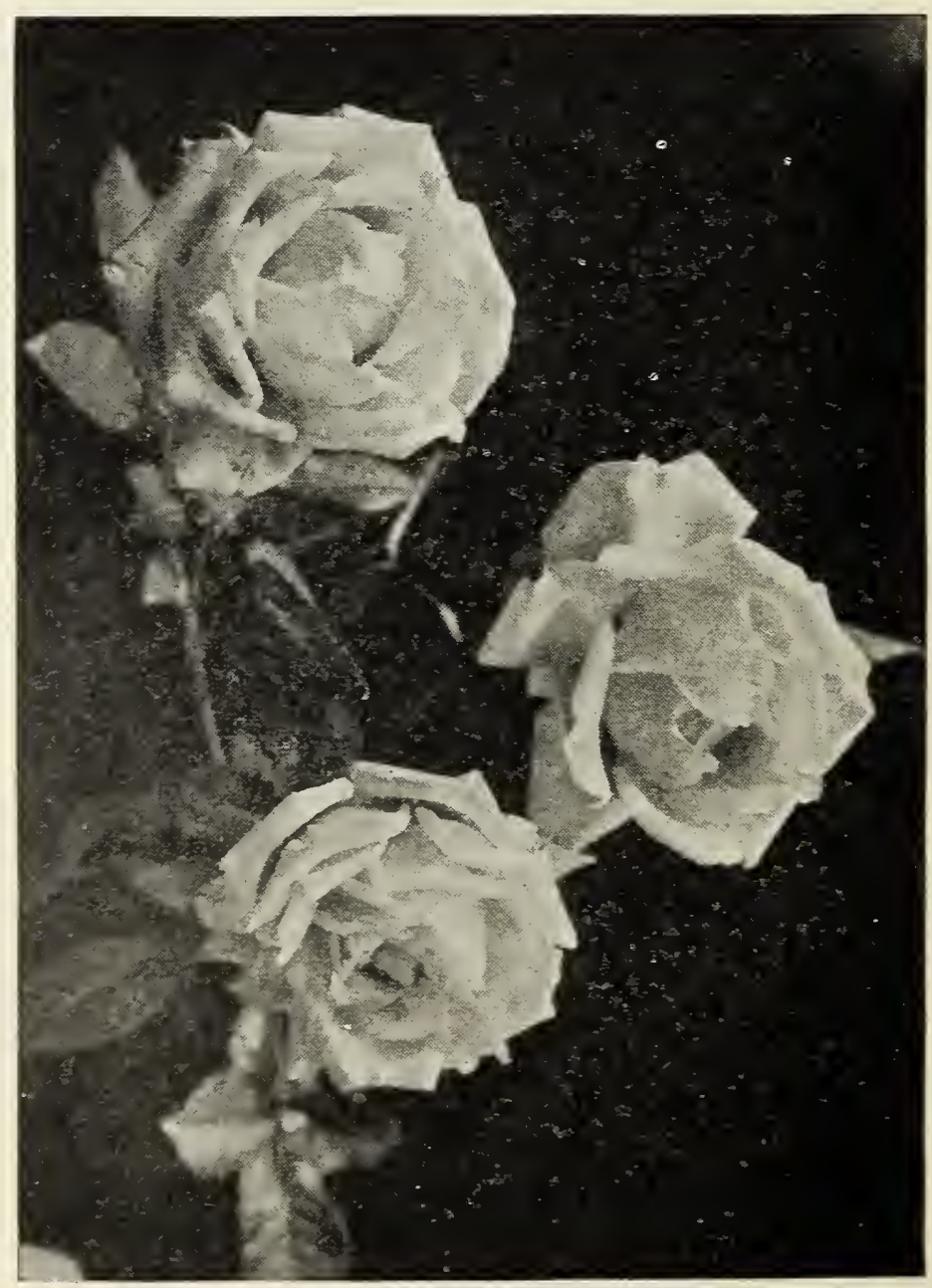

Gruss En Teplitz 


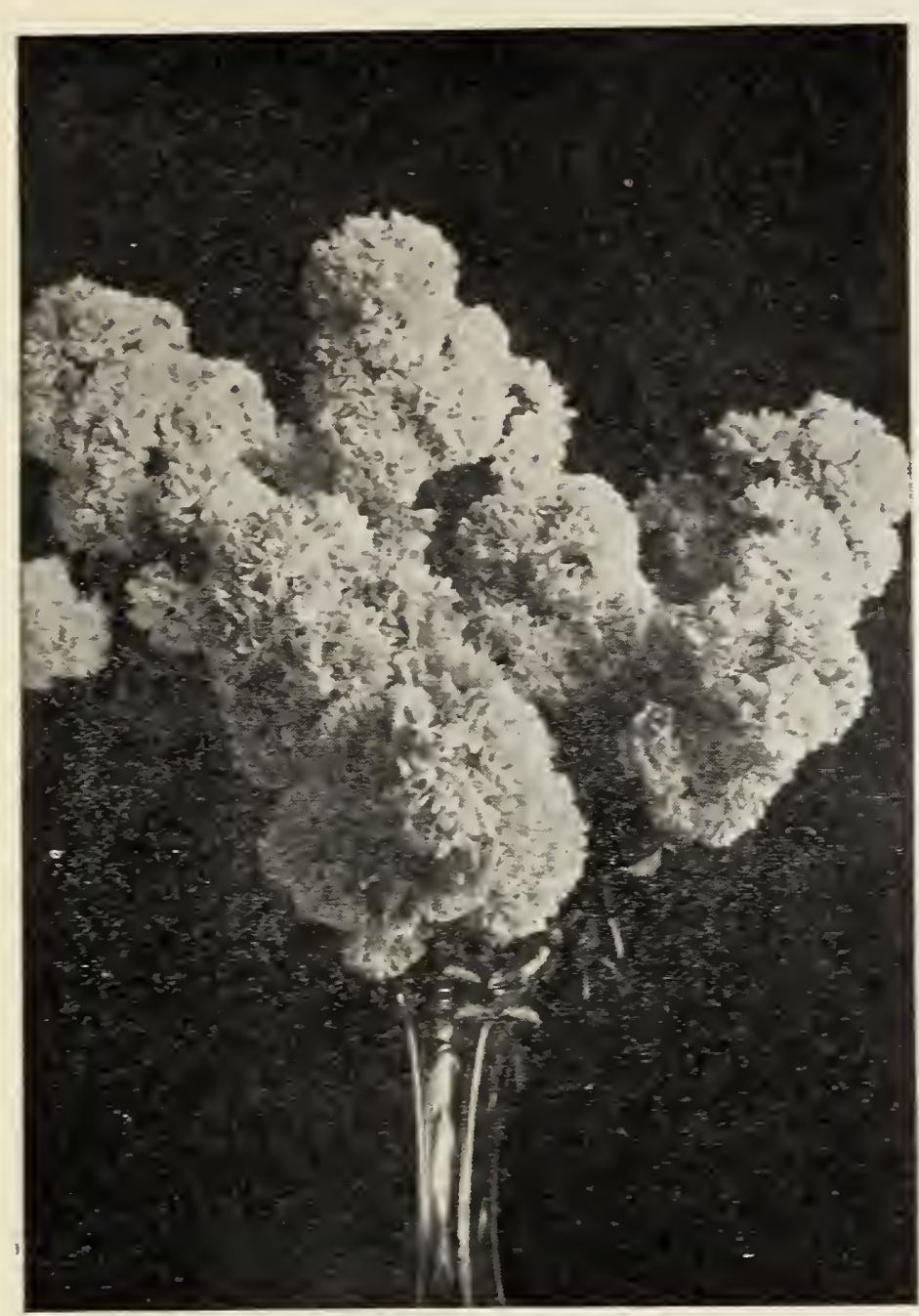

Dorothy Perkins

Magna Charta. Bright, rosy pink, very large and full; fragrant.

Margaret Dickson. White with pale flesh center, a strong grower, very fragrant.

Mrs. J. H. Laing. One of the finest roses of its class; color, soft delicate pink, very fragrant, a continuous bloomer throughout the whole season.

Paul Neyron. One of the largest and finest hardy roses grown; bright rose pink, very large, blooms continuously from June to November.

Ulrich Brunner. A spiendid upright grower, bright healthy foliage. An abundant bloomer. Bright cherry red.

\section{HYBRID TEA ROSES}

These are noted for their exquisite form, delicate shadings of color, delightful perfume and perpetual blooming; buds and flowers are produced at the terminal of every shoot; so it is only necessary to keep the plant growing thriftily to get bloom; not as hardy as the hybrid perpetual roses, but are well worth the extra protection and care required.

\section{All Varieties 2 Years, \\ $\$ 1.00$ Each; $\$ 9.50$ per 10 .}

Etoile de France. Intense brilliant crimson flowers on long, strong stems, very fragfrant and free blooming.

General McArthur. Deep, velvety scarlet, strong grower and a profuse bloomer; one of the best scarlet varieties.

Gorgeous. Flowers large and full, exquisitely formed and borne in great profusion. Deep orange yellow, flushed coppery yellow and heavily veined with coppery red.
Gruss en Teplitz. Bright scarlet-crimson, growing freely and blooming profusely. Quite hardy.

M. V. Machin. Intense scarlet-crimson; blackstained and velvety; large, full and high centered. This is one of the richest colored of the red everbloomers.

J. J. L. Mock. Very large, full, and fragrant; petals silvery, rosy white inside, outside carmine-pink.

Killarney. Exquisite form and fragrance. Bright pink marbled in white. Buds very long.

Killarney White. Similar to Killarney, except color, which is a creamy, often nearly pure white.

Lady Hillingdon. A deep apricot yellow, beautiful in bud and flower.

LaFrance. Peach-blossom pink, clouded with rosy flesh. Flowers very large and highly perfumed.

Los Angeles. Brilliant flame-pink, toned with coral and shaded with gold at the base of the petals. Buds are long and pointed.

Mad. Jules Bouche. A beautiful shade of white, overlaid and blended with salmon pink.

Mme. Caroline Testout. Brilliant clear pink, deepening at center, and bordered silvery rose.

Mme. Edouard Herriott. Coral-red, shaded with yellow and bright rosy scarlet.

Mrs. Aaron Ward. Buds long and shapely, opening cup shape; color, Indian yellow shaded salmon rose.

Mrs. A. R. Waddell. Long and pointed buds of rosy scarlet, opening coppery salmon. A continuous bloomer.

Wm. F. Dreer. Silver shell-pink petals, the base of each being rich yellow. Flowers large, double, and a profuse bloomer.

\section{POLYANTHA ROSES}

\section{(BABY RAMBLER)}

\author{
All Varieties 2 Years, \\ 75 Cts. Each; $\$ 7.00$ Per 10
}

Baby Rambler. A type of rose which is very popular for bedding purposes. They form shapely, compact, bushy specimens about 18 inches high, producing in great profusion from early in the season until severe frost, immense trusses of small flowers. Pruning is not necessary; simply remove the past season's flower stems. Bright crimson color.

Erna Teschendorf. Deep, unfading crimson, more dependable than the common Baby Rambler.

Rosa Rugosa. A valuable and perfectly hardy rose much used for landscape work; lustrous dark green foliage; is impervious to the attack of insect pests. Its single, highly scented flowers are followed by large, handsome scarlet fruits, persistent into the winter.

Alba. Pure white.

Rubra. Rosy crimson. 


\section{TREE ROSES}

The Tree Roses are grafted on hardy stems 4 to 5 feet high, and thus form tree shapes. When in full bloom they are very handsome and popular for formal gardens. $\$ 2.00$ each; $\$ 17.50$ per 10 .

In these we offer the following varieties:

Erna Teschendorf.

Gruss En Teplitz.

Mrs. J. H. Laing.

Pink Killarney.

Frau Karl Druschki.

\section{CLIMBING ROSES}

All Varieties $75 \mathrm{Cts}$. Each; $\$ 6.00$ Per 10

Crimson Rambler. The beautiful crimson clustered climber. Makes shoots from eight to ten feet long in a season. The best known climbing rose.

Dorothy Perkins. A beautiful shell-pink rose, having the same strong habit of growth as the Crimson Rambler. Very double, sweetly scented, and perfectly hardy.

Excelsa. Very deep pink, type of of Dorothy Perkins.

Flower of Fairfield. One of the best of the newer varieties, flowers of a fine crimson color. The growth is vigorous, flowering freely and continuously throughout the entire season.

Paul's Scarlet Climber. Vivid Scarlet. New.

White Dorothy Perkins. Similar to Dorothy Perkins but white.

\section{PEONIES}

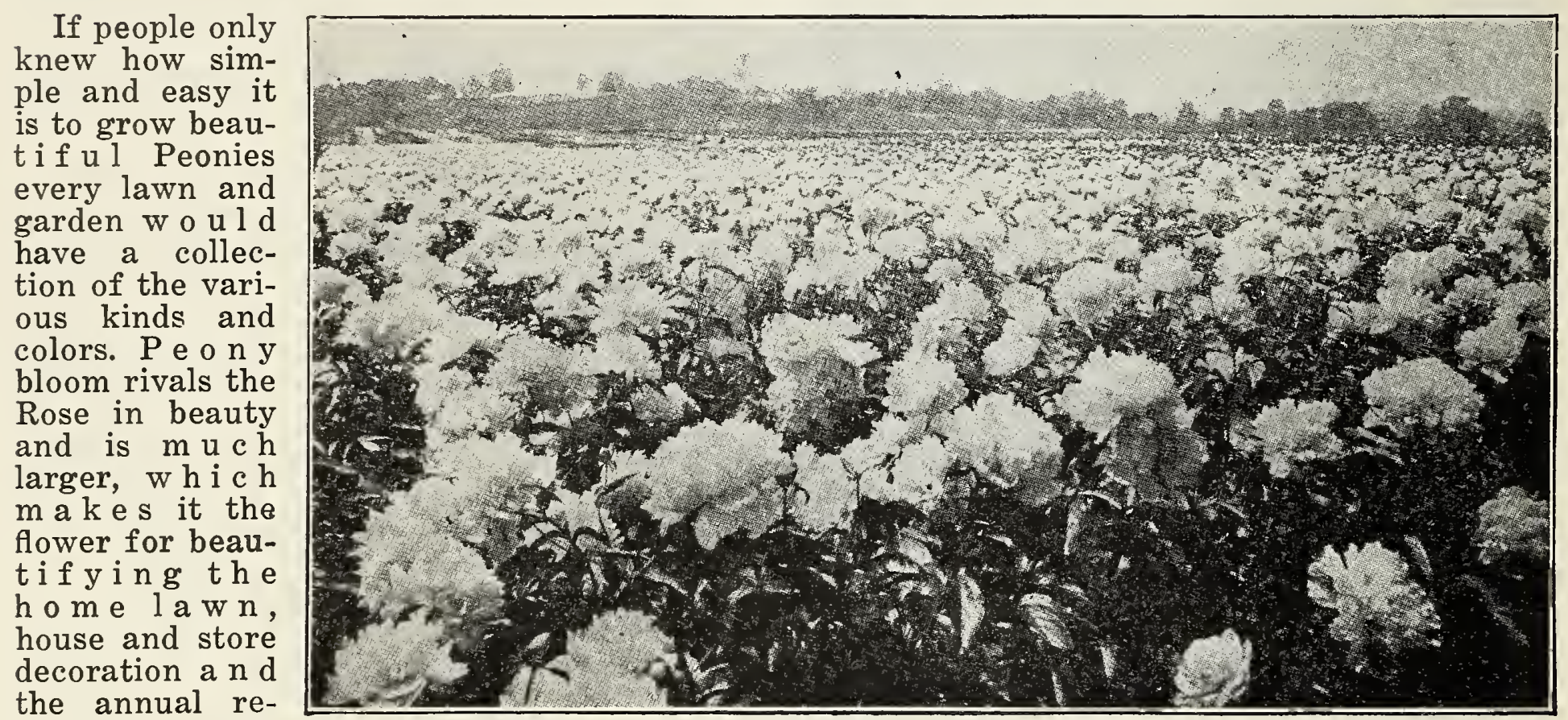

membrance o $\mathrm{n}$

the graves of your dead. The greatest advantage is that the plants and bloom are free from insect pests and do not have to be persuaded to bloom. Their bright colors and pleasing fragrance captivate people of every age, condition, location and race. In size they range from four to eight inches in diameter, some small and dainty, others massive and fluffy as any chrysanthemum, and a great many with a fragrance as charming and delicate as a rose. The modern Peony is certainly a marvel. 40 cts. each; $\$ 3.50$ per 10 .

Carnation. Red, very handsome, a free bloomer, very fragrant.

Duchess De Nemours. Pure white, with sulphur-white collar. Fragrant. Vigorous grower and free bloomer.

Ener. Flesh pink, chysanthemum center, a heavy bloomer, very pretty.
Festiva Maxima. Enormous flowers, clear white with an occasional carmine red spot on the edges of center petals. Handsome.

Grandiflora. Deep rose color, almost red, very fine.

Jupiter. Double pink, very handsome, strong, free bloomer.

Mrs. Fletcher. Double pink, very pretty.

Nigra. Dark red, very pretty.

Olive Logan. Rose pink, white center, handsome.

Pottsii. Dark red, yellow stamin, very attractive.

Rose Fragrans. Deep rose color, very fragrant, strong, free bloomer.

Terry's No. 1. Deep pink outer petals, flesh center, pretty. 


\section{CLIMBING VINES}

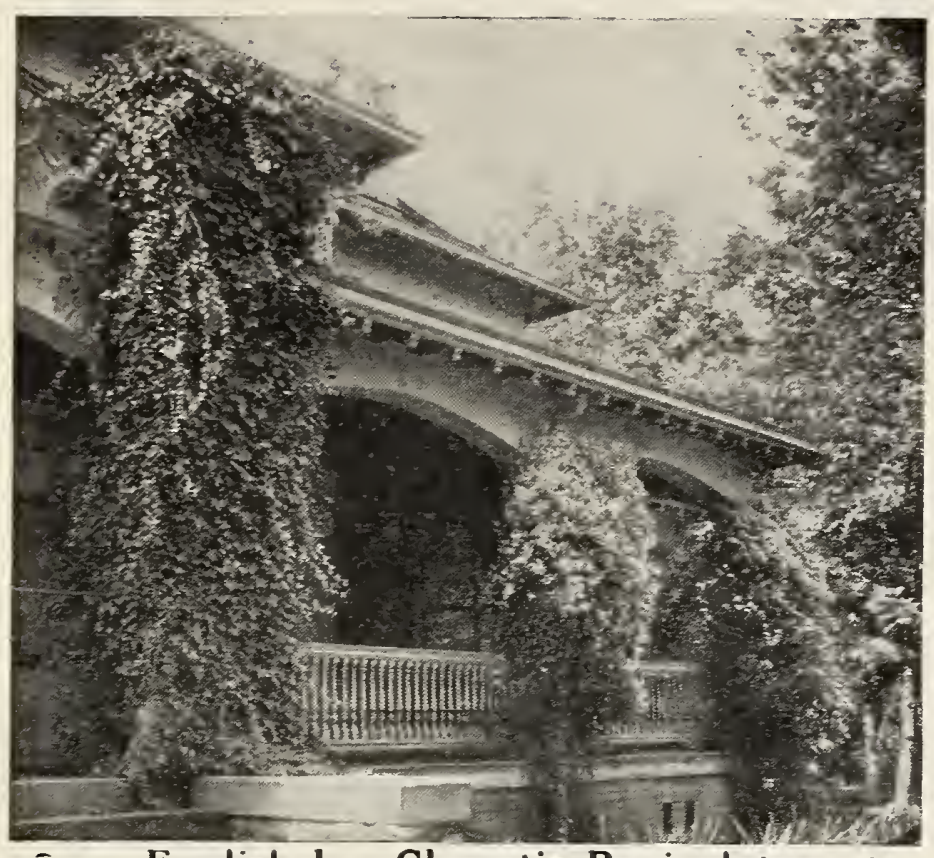

English lvy Clematis Paniculata

AMPELOPSIS VEITCHII. (Boston Ivy.) One of the finest climbers for covering walls, as it clings to smoothest surface, covering it with a mass of foliage. The color is a bright green in summer, changing to bright shades of crimson and yellow in the fall. $75 \mathrm{cts}$. each; $\$ 6.00$ per 10 .

AMPELOPSIS ENGELMANII. Deeply cut leaves which turn to beautiful crimson in fall. Fine for covering trees, walls, etc. 50 cts. each; $\$ 4.00$ per 10 .

ARISTOLOCHIA SIPHO. (Dutchman's Pipe.) Large leaves; brownish flower resembling a miniature pipe. $\$ 1.00$ each; $\$ 9.00$ per 10 .
CLEMATIS HENRYI. Large, creamy white flowers of fine shape. $\$ 1.00$ each; $\$ 9.00$ per 10.

CLEMATIS JACKMANI. Very large, velvety violet-purple flowers. Blooms continually from July until frost. $\$ 1.00$ each; $\$ 9.00$ per 10.

CLEMATIS MADAME EDOUARD ANDRE. Very large flowers of a distinct crimson-red. $\$ 1.00$ each; $\$ 9.00$ per 10 .

CLEMATIS PANICULATA. A very rapid grower with handsome, clean, glossy foliage. The flowers of medium size, fragrant, pure white, produced in great profusion in September. 40 cts. each; $\$ 3.50$ per 10 .

HONEYSUCKLE. (Hall's Japan.) Pure white changing to creamy yellow, very fragrant, in bloom the whole season. Valuable for covering banks or bare places where grass will not grow. 50 cts. each; $\$ 4.00$ per 10 .

HONEYSUCKLE. (Scarlet Trumpet.) Flowers scarlet and trumpet shaped. 50 cts. each; $\$ 4.00$ per 10 .

CHINESE MATRIMONY VINE. Is sometimes trained as a shrub. Purple flowers followed by showy fruit. 40 cts. each; $\$ 3.00$ per 10 .

WISTARIA MAGNIFICA. Flowers in dense drooping racemes of pale lavender. $60 \mathrm{cts}$. each; $\$ 5.00$ per 10 .

WISTARIA SINENSIS ALBA. Same as the above only having pure white flowers. 75 cts. each; $\$ 6.50$ per 10 .

\section{HARDY PERENNIALS}

$\mathbf{I}^{\mathrm{T}}$ T IS ALWAYS WELL to have plants that come up year after year without replanting. In our offering of hardy plants we have selected 'varieties which can be grown satisfactorily by the amateur and which thrive in a large variety of soils. These can be used to best advantage in groups and beds on the lawn, as borders for drives, walks, or in front of shrubbery, and in the garden, and many varieties make beautiful bouquets for indoor use when cut. For your convenience we have specified the purpose for which each variety is best adapted as follows:

(S) sunny or nearly sunny positions. (P) shady or semi-shady positions. (C) best for cut-flowers. $(\mathrm{R})$ rock garden varieties.

(C) (S) ACHILLEA-Boule de Neige. Very valuable for cutting or border, a dwarf form of The Pearl, with larger ball-shaped flowers. $20 \mathrm{cts}$. each; $\$ 2.00$ per 12 .

(S) AGROSTEMMA-Coronaria. (Rose Campion.) Thrifty growing plants with silvery foliage, two to three feet in height, with a profusion of bright crimson, Phlox-shaped flowers during June and July. 20 cts. each; $\$ 2.00$ per 12 .

(R) (P) AJUGA-Reptans. An excellent plant for shady places, carpeting the ground under trees where grass will not grow. Ex- tensively used in the rockery. Grows 3 to 4 inches high, bearing deep, purplish-blue flowers in May and June. 20 cts. each; $\$ 2.00$ per 12.

(R) (S) ALYSSUM - Saxatile Campactum. A dwarf-growing plant, about 10 inches, well adapted for rockery or border. Dense masses of yellow bloom in early summer. 20 cts. each; $\$ 2.00$ per 12.

(S) ANCHUSA-Italica Dropmore. A very strong growing perennial, producing immense, branching spikes 4 to 5 feet high, covered in June with pretty gentian-blue flowers about an inch across. 25c each; $\$ 2.50$ per 12. 


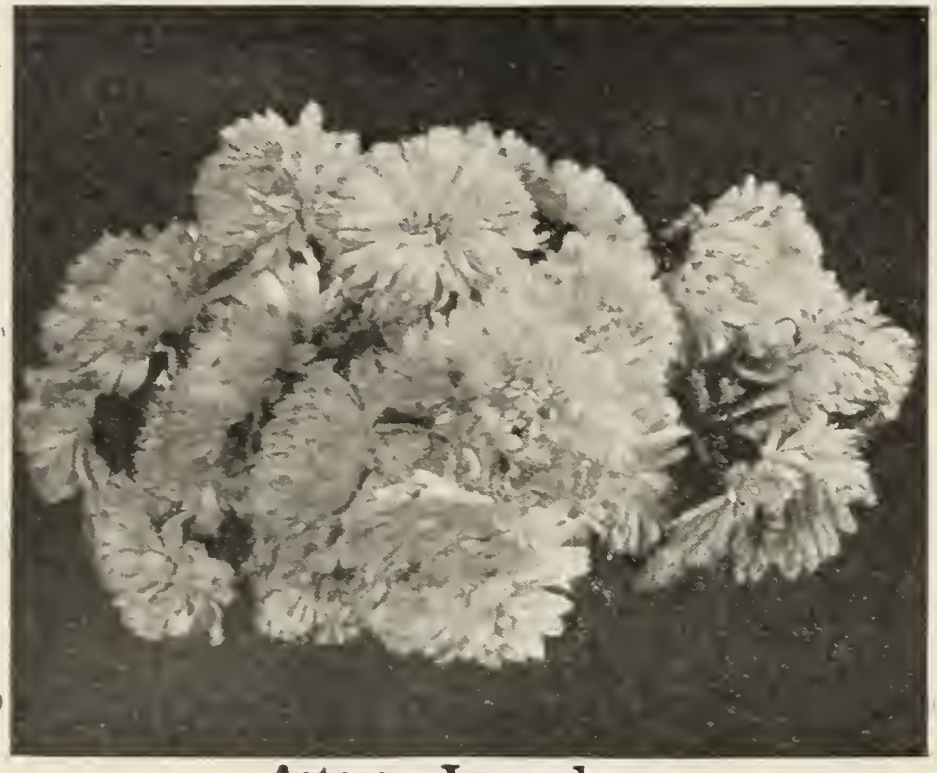

Asters-Lavender

(S) AQUILEGIA-Columbine. One of the most beautiful old-fashioned plants, blooming in May and June. Their delicately shaded, graceful flowers make them indispensable for the hardy garden. 20 cts. each; $\$ 2.00$ per 12 .

Canadensis. Native. Red and yellow.

Chrysantha. Clear yellow.

Caerulea. Rocky Mountain Columbine. Blue and white.

Skinneri. Yellow, with long red spurs.

Scott Eliott. Long spurred Hybrids. A splendid mixture of the most delicate Columbine colors.

(R) (S) ARMERIA-Dwarf plants forming evergreen tufts of bright green grass-like foliage, from which numerous flowers appear in compact heads on stiff, wiry stems 9 to 12 inches high. These plants bloom almost constantly from Spring till Fall and are thrifty growers in most any soil. Very useful as a border.

20 cts. each; $\$ 2.00$ per 12 .

Laucheana. Lavender-pink.

Formosa. Bright rose.

(S) ARTEMESIA-Lactiflora. Deep green, finely cut foliage, with erect branching stems of fragrant creamy white flowers in August and September. 4 to $4 \frac{1}{2}$ feet. $20 \mathrm{c}$ each; $\$ 2.00$ per 12 .

(S) ASCLEPIAS-Tuberosa. A very attractive native plant, producing broad heads of bright orange bloom during July and August. 2 to $2 \frac{1}{2}$ feet in height. 20 cts. each; $\$ 2.00$ per 12 .

(S) HARDY ASTERS-These plants are valuable for their wealth of bloom in early fall when the blooming season of most perennials is over. $25 \mathrm{c}$ each; $\$ 2.50$ per 12 .

Abendrothe. Rose. 4 feet.

Climax. Pyramidal spikes of large, light lavender blue flowers with prominent yellow center. One of the best. $5 \mathrm{ft}$.

Feltham Blue. Free flowering, sky-blue.

(R) Mauve Cushion. Dwarf growing, soft mauve, fine for late border.

Mrs. Raynor. The deepest red Aster. $3 \mathrm{ft}$. St. Egwin. Exceptionally free, pink. $2 \mathrm{ft}$.

White Climax. Pure white. $4 \mathrm{ft}$.

(S) BAPTISIA-Australis. Attractive deep green foliage with spikes of deep blue flowers in June. A strong grower, about $2 \mathrm{ft}$. 15 cts. each; $\$ 1.50$ per 12 .
(S) CAMPANULA-Media Calycanthema. (Cup and Saucer.) Blue, rose and white. $20 \mathrm{c}$ each; $\$ 2.00$ per 12 .

(S) CENTAUREA-Montana. Bears large, loose-petaled, violet-blue flowers from July to September. $2 \mathrm{ft}$. high. $15 \mathrm{cts}$. each; $\$ 1.50$ per 12 .

Montana Alba. White form of the above. 15 cts. each; $\$ 1.50$ per 12 .

(C) (S) CHRYSANTHEMUMS - These are among the latest blooming perennials and make it possible to keep a good assortment of colors, both for cutting and for show, right through to the end of the season. 20 cts. each; $\$ 1.75$ per 12 .

Alice Howell. Orange yellow, large.

Autumn Glow. Rose-pink. Large.

Eva. A dwarf grower, bright pink, very useful as a late border.

Fields of Snow. Pure white, tinged when old with light red. Button.

Gipsy Queen. Reddish bronze. Large.

Indian. Copper red.

Little Bob. Reddish bronze. Button.

Lillian Doty. Deep pink. Excellent form, large.

Victory. White, large flowered.

Yellow Button.

(R) (P) CONVALLARIA Majalis. (Lily of the Valley.) Clumps. 35 cts. each; $\$ 3.50$ per 12

(C) (S) COREOPSIS-Lanceolata. A very hardy, strong growing perennial about 18 inches high, bearing a profusion of bright yellow daisy-like flowers, very useful for cutting. By keeping old flowers cut off will bloom nearly all season. 15 cts. each; $\$ 1.50$ per 12 .

(C) (S) DAISY-Shasta, Alaska. Large white flowers in large quantity throughout fall. Very good for cutting. $15 \mathrm{c}$ each; $\$ 1.50$ per 12.

(C) (S) DELPHINIUMS-A very satisfactory plant in the hardy garden, giving shades of blue from June until frost which are hard to obtain elsewhere. Also one of the most valuable and profitable cut-flowers. 20c each; $\$ 2.00$ per dozen.

Belladonna. Turquoise blue. The most continuous and profuse blooming Delphinium, bearing flowers from the last of June until frost. Two-year-old clumps.

Bellamosum. Dark blue form of the above. Two-year-old clumps.

English Hybrids. A marvelous assortment of all the shades of blue, flowers borne in spikes of unusual length. A very good strain with both double and single flowers. Two-year-old clumps.

(S) DIANTHUS BARBATUS-Very popular old-fashioned flowers bearing broad heads of showy bloom during May and June. 15 cts. each; $\$ 1.50$ per 12 .

White Beauty.

Johnson's Giant. The best of the Sweet Williams, bearing immense heads of flowers in a riot of color.

Latifolius Atrococcineus. (Everblooming Sweet William.) In constant bloom from early June until frost. Flowers are brilliant crimson and double. Very showy.

Newport Pink. Deep salmon-pink.

Nigrencens. Deep velvety crimson. Dark green, thrifty foliage. 
(R) (S) (P) DICENTRA-Eximea. (Plumy Bleeding Heart.) A dwarf growing variety of Dicentra and with very attractive, finely cut foliage, bearing racemes of pretty heart-shaped, pink flowers throughout the season. A desirable plant, doing well either in shade or sun. 25c each; $\$ 2.50$ per 12 .

(C) (S) DIGITALIS-Gloxinaeflora. A very showy old-fashioned plant bearing immense spikes of thimble-shaped flowers during July and August. Separate colors, rose, purple, and white. 20 cts. each; $\$ 2.00$ per 12.

(S) EULALIA-Ornamental grasses extensively used for bedding and as specimens. Very distinctive in appearance and hold a uniform attractiveness throughout the season. 25 c each; $\$ 2.50$ per 12 .

Gracillima Univittata. Long, narrow, green leaves with silver midrib. 4 to 5 feet.

Japonica Variegata. Long narrow leaves, striped green and white. 4 feet.

Zebrina. Green leaves crossed every 2 to 3 inches with broad bands of yellow. 4 to 5 feet.

(C) (S) EUPATORIUM - Coelestinum. A dense mass of blue Ageratum-like flowers during August and September. Very useful for cutting. $2 \mathrm{ft}$. 20 cts. each; $\$ 2.00$ per 12.

(S) FUNKIA-Media Variegata. A dwarfgrowing plant with broad variegated green and white leaves. Unexcelled as a dwarf border plant. 20 cts. each; $\$ 2.00$ per 12 .

(S) Glauca. A Japanese variety, with attractive bluish foliage. 40 cts. each; $\$ 4.00$ per 12.

(P) Lanceolata. Dark, glossy green foliage, with stems of delicate lilac flowers in September. A useful shade plant. 20 cts. each; $\$ 2.00$ per 12 .

(P) Subcordata Grandiflora. Very attractive light green foliage, bearing fragrant, white, lily-shaped flowers in August. 40 each; $\$ 4.00$ per 12 .

(C) (S) GAILLARDIA-Grandiflora. This is one of the most beautiful of the perennial plants, bearing a multitude of blooms from June till frost. Petals are of orange and yellow, strikingly ringed by circles of maroon, crimson and red, with a hard deep maroon cone for center. Will make a gorgeous display in any soil. 20 cts. each; $\$ 2.00$ per 12 .

(S) GEUM-Mrs. Bradshaw. Brilliant scarlet, carnation-like flowers on long slender stems from June till September. 15 inches. 20 cts. each; $\$ 2.00$ per 12 .

(C) (S) GYPSOPHILA-Paniculata. A dense, spreading bush, forming a mound 2 to 3 feet high, and during July and August is mass of minute white flowers, the sprays of which are very useful for cutting with other flowers. Strong 2-year roots. $15 \mathrm{cts}$. each; $\$ 1.50$ per 12 .

(S) HELENIUM-Riverton Gem. A very strong-growing plant forming a large rounded bush covered with small old-gold blooms, changing to the rich autumn shades of red and brown. A very striking plant, either as a specimen or in the perennial border. 20 cts. each; $\$ 2.00$ per 12 .

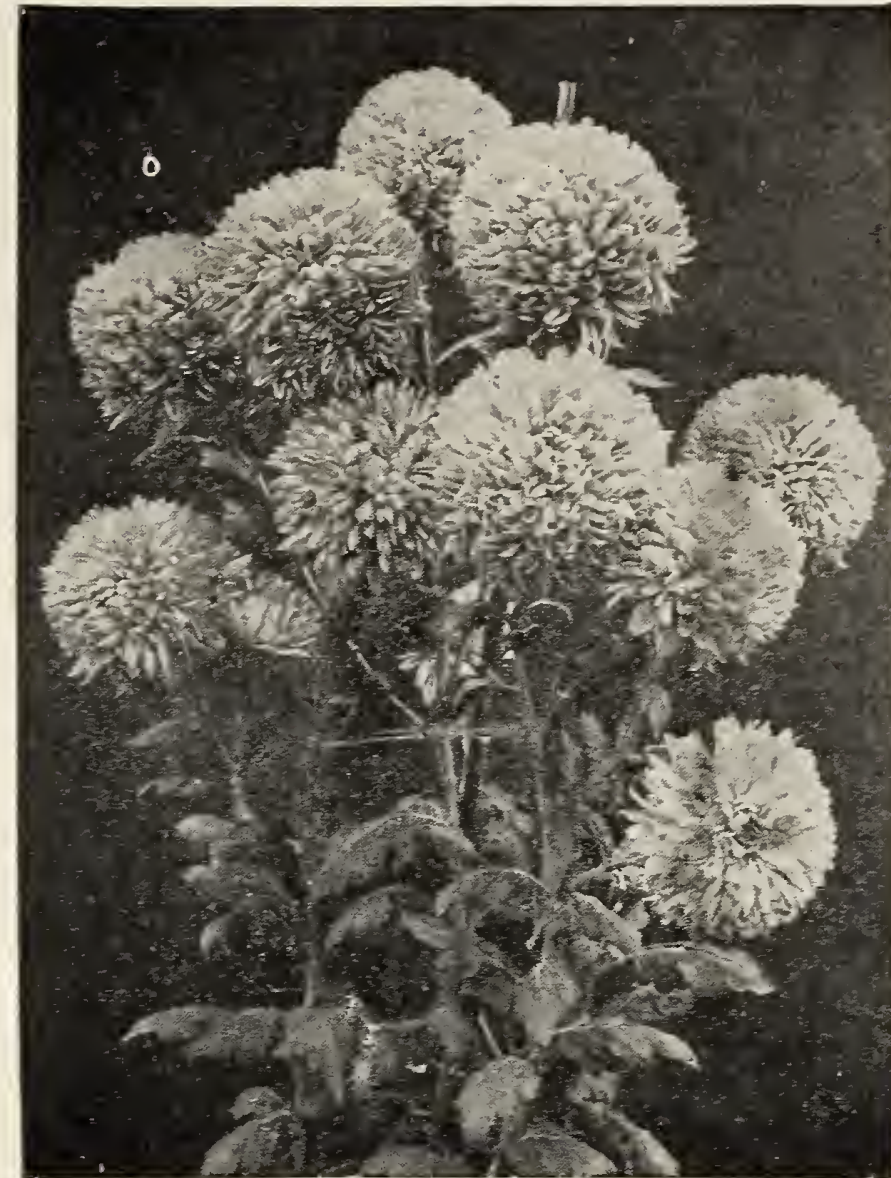

Chrysanthemams

(C) (S) HELIOPSIS-Pitcheriana. Orangeyellow, daisy-like flowers, with a brown pyramidal center. Very good for cutting. $15 \mathrm{c}$ each; $\$ 1.50$ per 12 .

(S) HIBISCUS-Meehan's Marvel. Red, pink and white, separate. 20 cts. each; $\$ 2.00$ per 12.

Mixed. Each 15 cts; $\$ 1.50$ per 12 .

(S) HEMEROCALLIS-Flava. (Lemon Lily.) Panicles of lemon yellow sweet-scented flowers 3 to 4 inches across. $3 \mathrm{ft} .20 \mathrm{cts}$. each; $\$ 2.00$ per 12 .

Dr. Regel. Deep orange-yellow flowers during May. Very fragrant, and useful for cutting. $1 \frac{1}{2} \mathrm{ft} .20 \mathrm{c}$ each; $\$ 2.00$ per 12.

Middendorfii. Dark green foliage, clusters of bright yellow flowers 5 to 6 inches long. Blooms during May and June. $2 \frac{1}{2} \mathrm{ft} .15$ cts. each; $\$ 1.50$ per 12 .

Thunbergi. The latest blooming Hemerocallis, bearing funnel-shaped flowers of buttercup yellow during July. $4 \mathrm{ft}$. $15 \mathrm{c}$ each; $\$ 1.50$ per 12.

(P) HEPATICA-Triloba. A native plant with low luxuriant foliage, bearing small bright blue flowers in early spring. Very good for naturalizing or use in deep shade. 15 cts. each; $\$ 1.50$ per 12 .

(S) HOLLYHOCK-Double Crimson, yellow, white, maroon and pink. 20c each; $\$ 2.00$ per 12 .

Allegheny. Mixed.

(R) (S) IBERIS-Sempervirens. Hardy white Candytuft. Dark, shiny evergreen foliage, hidden in early spring with dense panicles of pure white flowers. A dwarf-growing plant, much used in rock gardens. 20 cts. each; $\$ 2.00$ per 12 . 
(C) (S) IRIS GERMANICA-A group of varieties valuable as cut-flowers as well as for their ornamental beauty. Our beds are fresh planted and you may be sure of getting good strong plants. 20 cts. each; $\$ 2.00$ per 12 . *25 cts. each; $\$ 2.50$ per 12 .

Midnight. Standards and falls uniformly deepest purple.

Lohengrin. Very large flowers of one color, soft cattleya rose.

Monsignor. Standards violet. Falls crimson-purple with gleaming violet veins.

Celeste. Uniformly colored flowers of azure blue.

Her Majesty. Standards lavender-rose, falls crimson tinged with white.

Honorabilis. Standards clear yellow, falls maroon.

*Isoline. Standards pale lavender, falls light purple overlaid with brown. Large.

Nieblungen. Standards fawn, falls violet, very attractive.

Pallida Mandralisca. Standards azure. Falls deep blue.

Parisiensis. A uniform deep purple, falls penciled white.

Tamerlane. Standards light blue, falls deep purple. Very luxuriant.

(S) LAVENDULA-Vera. This is the true Sweet Lavender. It grows about 18 in. high and bears fragfrant spikes of blue flowers during July and August which retain their odor when dried. 25 cts. each; $\$ 2.50$ per 12

(C) (S) LATHYRUS-Latifolius. (Everlasting Sweet Pea.) One of the most attractive hardy climbing plants, from the standpoint of both foliage and plants, from the standpoint of both foliage and
flowers, growing 8 to $10 \mathrm{ft}$. high when trellised, and bearing clusters of large Sweet Pea-like flowers the entire season, which are excellent for cutting. Red, pink, or white. $25 \mathrm{cts}$. each; $\$ 2.50$ per 12 .

(R) (S) LINUM-Perennae. Light green, graceful foliage, covered with pale blue flowers during July and August. A plant extensively used in the rockery. About 18 inches high, inclined to horizontal growth. $15 \mathrm{cts}$. each $\$ 1.50$ per 12

(S) LYCHNIS-Chalcedonica. Heads of brilliant scarlet bloom from late June till August. A very conspicuous plant. 20 cts. each; $\$ 2.00$ per 12 .

(R) Viscara Splendens. Sends up spikes of bright crimson flowers about a foot high during July and August. Foliage in dense tufts, almost evergreen. Perhaps the brightest of the hardy perennials. 25 cts. each; $\$ 2.50$ per 12 .

(S) MONARDA-Cambridge Scarlet. Forms dense clumps, producing brilliant crimson flowers on stems 2 to 3 feet long during July and August. Foliage highly aromatic. $15 \mathrm{cts}$, each; $\$ 1.50$ per 12 .

(R) (P) MYOSOTIS-Palustris. The true "Forget-menot," bearing its azure-blue, yellow-centered flowers in profusion during early summer, and prized for its sentiment. $15 \mathrm{cts}$. each; $\$ 1.50$ per 12 .

(S) PAPAVER-Poppy.

(R) Nudicaule. (Iceland Poppy.) Low tufts of light green, fern-like foliage from which spring slender leafless stems $1 \mathrm{ft}$. high, each bearing a pretty, 2 inch, saucer-shaped flower. Blooms very profusely in early summer and in a lesser degree throughout the season. Orange or white. 20 cts. each; $\$ 2.00$ per 12.

Oriental Mixed. These are grown from the seed of the largest-flowered perennial poppies and contain a good variation of color. $25 \mathrm{cts}$. each; $\$ 2.50$ per 12 .

(S) HARDY PHLOX-Strong, field-grown plants.

Athis. Salmon-pink. 20 cts. each; $\$ 2.00$ per 12 .

B. Compte. Rich ox-blood red. A strong, luxuriant grower. 35 cts, each; $\$ 3.50$ per 12 .

La Vague. Rosy mauve with carmine eye. 20 cts. each; $\$ 2.00$ per 12 .

Miss Lingard. Pearly white with delicate lavender eye. The earlieist bloomer, bearing two or three crops of flowers during the season. Free from attacks of red spider. 20 cts. each: $\$ 2.00$ per 12 .

Mrs. Jenkins. An early blooming pure white. $20 \mathrm{cts}$. each; $\$ 2.00$ per 12

Mrs. Dwyer. White with large rose eye. 20 cts. each, $\$ 2.00$ per 12 .

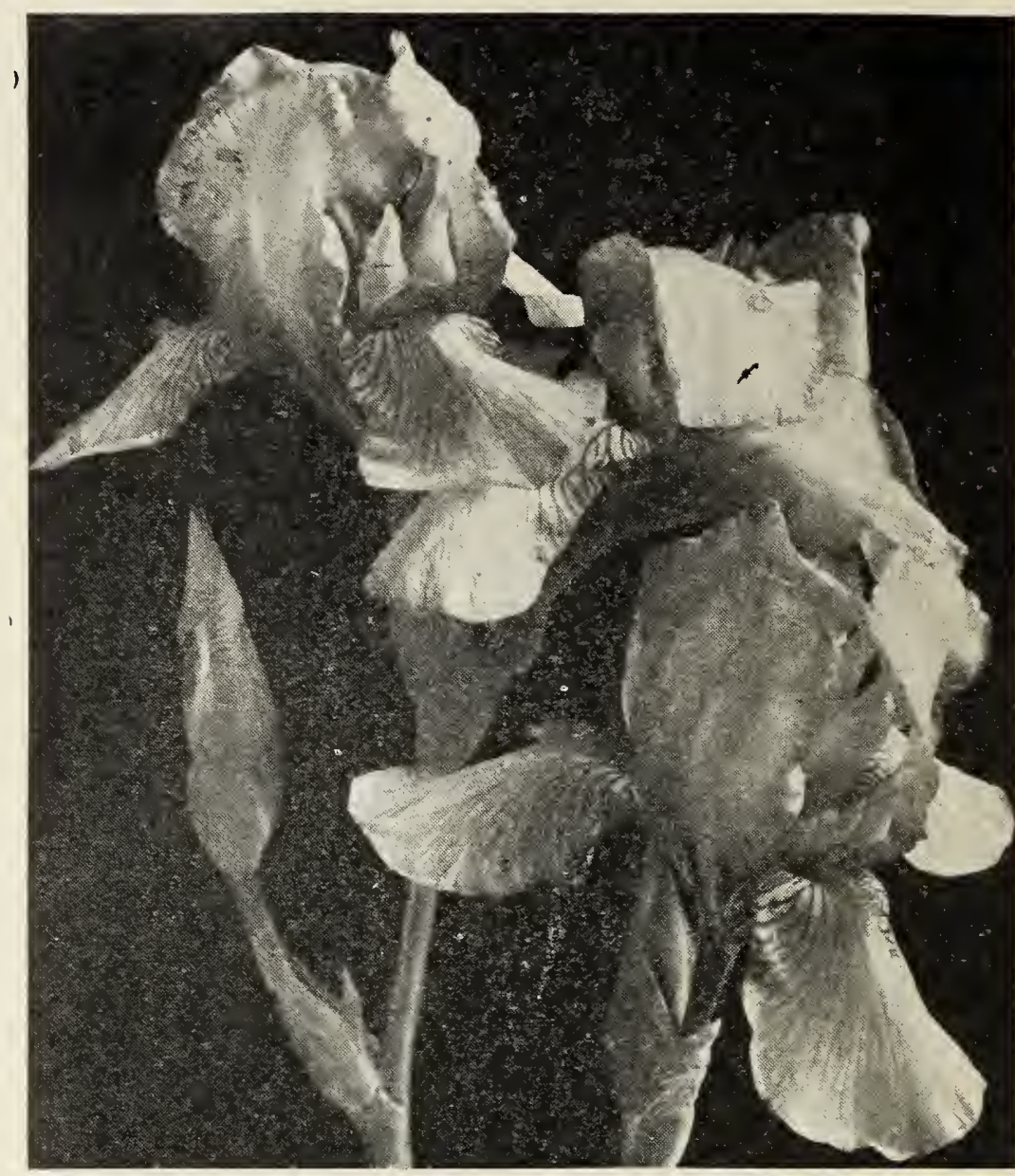

Garden Iris-Celeste

Rheinlander. Large trussed. Bright salmon-pink, large florets. $30 \mathrm{cts}$. each; $\$ 3.00$ per 12

Seiboldii. Light crimson. 20 cts. each; $\$ 2.00$ per 12.

Von Lassburg. Pure white, large heads of bloom. 25 cts. each; $\$ 2.50$ per 12 .

(R) Subulata Rosea. (Moss Pink.) Used extensively as a ground cover. The moss-like foliage is a mass of bright pink bloom in April and May. 20 cts. each; $\$ 2.00$ per 12

(R) Subulata Alba. A pure white form of the above. 20 cts. each; $\$ 2.00$ per 12 .

(R) Amoena. A very useful dwarf species, excellent as a ground carpet, in the rockery, or the perennial border. It attains a height of only 3 to 4 inches, and in spring is a sheet of brightest pink flowers. 15 cts. each; $\$ 1.50$ per 12 .

(S) PINKS-These old favorites are at their best in May and June, bearing their clove-scented flowers in great profusion. They are valuable both in the hardy border and for cutting. 20 cts. each; $\$ 2.00$ per 12.

Essex Witch. Pink, fringed flowers.

Her Majesty. Pure white.

Erfurt. Dwarf-growing, with double flowers in various showy colors.

(C) (S) PHYSALIS-Franchetti. (Chinese Lantern Plant.) This ornamental variety of Winter Cherry forms dense bushes about $2 \mathrm{ft}$. high and bears its orange-scarlet, lantern-like fruits in profusion. These are extensively used for floral decoration when dried. 20 cts. each; $\$ 2.00$ per 12

(S) PLATYCODON-Grandiflorum. Bears numerous balloon-shaped flowers constantly from July till late September. Does well in any soil. Blue or white. 15 cts. each; $\$ 1.50$ per 12 .

(R) (P) PRIMULA-Veris. (English Cowslip.) A pleasing strain of hardy Primrose, bearing flowers in Spring in a wide range of color. It thrives best in a partially shaded, open position, in rich soil. Equally attractive in the perennial border or rock garden. 20 cts. each; $\$ 2.00$ per 12 .

(C) (S) PYRETHRUM-Hybridum. Fine-cut, fern-like foliage, with attractive daisy-like flowers on long, graceful stems in all the shades of red and pink. Excellent for cutting. June and July. 20 cts. each $\$ 2.00$ per 12 . 
(S) PLUMBAGO-Larpentae. A highly desirable bor. der plant. Uniform habit of growth, about 12 inches hich and very compact. Bears clusters of bright cobalt blue flowers from August till frost, attractively set off by the apple-green foliage. 20 cts. each; ly set off by
$\$ 2.00$ per 12 .

(S) RUDBECKIA-Purpurea. A disitinctive perennial, fowers about 4 inches across, the petals of a peculiar reddish purple, with a remarkable large cone-shaped center of brown. 2 to 3 feet. July till frost. 20 cts. each: $\$ 2.00$ per 12 .

Golden Glow. An old-fashioned favorite. Thrifty growing, attaining a height of from 5 to $6 \mathrm{ft}$., and produces a profusion of double, golden-yellow, Cactus Dahlia-like flowers from July to September. 20 cts. each; 32.00 per 12 .

(S) SALVIA-Azurea Grandifiora. A hardy species of Salvia bearing a profusion of sky-blue flowers during August and September. A very graceful plant, with swaying flower wands 3 to 4 feet high. 15 cts. each $\$ 1.50$ per 12

(R) (S) SAPONARIA-Ocymoides. A tery pretty ar ereeper, covered with small bright pink flowers during July and August. $15 \mathrm{cts}$, each; $\$ 1.50$ per 12

Ocymoides Alba. White form of the above. 15 ct. eacli: $\$ 1.50$ per 12

(S) SEDUM (Stonecrop). The dwarf varieties are unexcellent as roc' garden plants, liking sunny positions, and the taller types make effective and unfailing color groups in the hardy border. These drouth. resisting plants thrive in almost any soil.

(R) Acre. (Golden Moss.) Dwarf. Much used for carpeting. Foliage green, flowers bright yellow. 20 cts. each: $\$ 2.00$ per 12

(R) Glaucum. Dwarf. Bluish white foliage. Excellent for edging or rockery. $20 \mathrm{cts}$. each: $\$ 2.00$ per 12

(R) Stahlii. Dwarf. Compact growing, with foliage an attractive crimson in tall. 20 cts. each $\$ 2.01$ por 12

Spectabile, Erect Grows $1 \gamma$ inches high, with broad. thick light green leaves, and bears immense heads of attractive rose-colored flowers in August and of attractive rose-colored flowers in
September. 20 cts. each: $\$ 2.00$ per 12

Spectabile Brilliant. Briyht red form of the above 25 cts each: $\$ 2.50$ per 12
(C) (S) STATICE-Latifolia. Grows 15 to 18 inches high with tufts of leathery leaves. Bears immense heads of very minute light blue flowers. Excellent for cutting with other flowers and if cut and dried will last for months $25 \mathrm{cts}$. each; $\$ 2.50$ per 12 .

(S) STOKESIA-Cyanea Blue. Bears freely lavenderblue flowers, of centaurea shape, 4 to 5 inches acros 8 . 20 cts. each; $\$ 2.00$ per 12 .

(C) (S) TRITOMA-Pfitzerii. An improved type of Red Hot Poker. Blooms during August and Septem. ber. 25 cts. each; $\$ 2.50$ per 12 .

(S) VERONICA-Incana. Silvery foliage with spikes of amethyst blue flowers about a foot high. July to August. 20 cts. each; $\$ 2.00$ per 12

Longifolia Subsessilus. An attractive border plant, With rough, deep green foliage, bearing numerous spikes of pretty deep blue flowers during July and August. 2 feet. 20 cts. each; $\$ 2.00$ per 12 .

(R) (P) VINCA-Minor. An evergreen creeper, extensively used for ground cover in the shade where grass will not grow. Single light blue flowers in June and July. 15 ets, each; $\$ 1.50$ per 12 .

(R) (P) VIOLA-These improved forms of Viola Cor. nuta flower continually from early spring till fall. While they are not as large as the Pansy, their clear colors and abundant bloom are fast gaining them popularity. 15 cts. each: $\$ 1.50$ per 12

Admiration. Light blue.

Lutea Splendens. Bright yellow.

White Perfection. Clear whitie.

(S) YUCCA-Filamentosa. Broad, sword-like, evergreen foliage. In midsummer bears erect branching stems of pendant, creamy white bells. Equally attractire and showy as specimens or in group planting. 4 to 6 feet. Strong 2 year plants. 25 ct. each $\$ 2.50$ per $1 \%$

Filamentosa Variegata. This plant is a variegated form of Yucca Filamentosa, and resembles it closely in torm, habit and bloom, bearing its panicled, creamcolored flowers on a stiff 3 to $4 \mathrm{ft}$. stalk for the first time when the plant is 3 years old. The bayonet-like leaves are dark bronze-green at center. with intermediate stripes to a broad yellow band on each edge. An outstanding plant, keeping its attractiveness the year round: Two-year plants, $\$ 1.00$ each.

\section{INDEX}

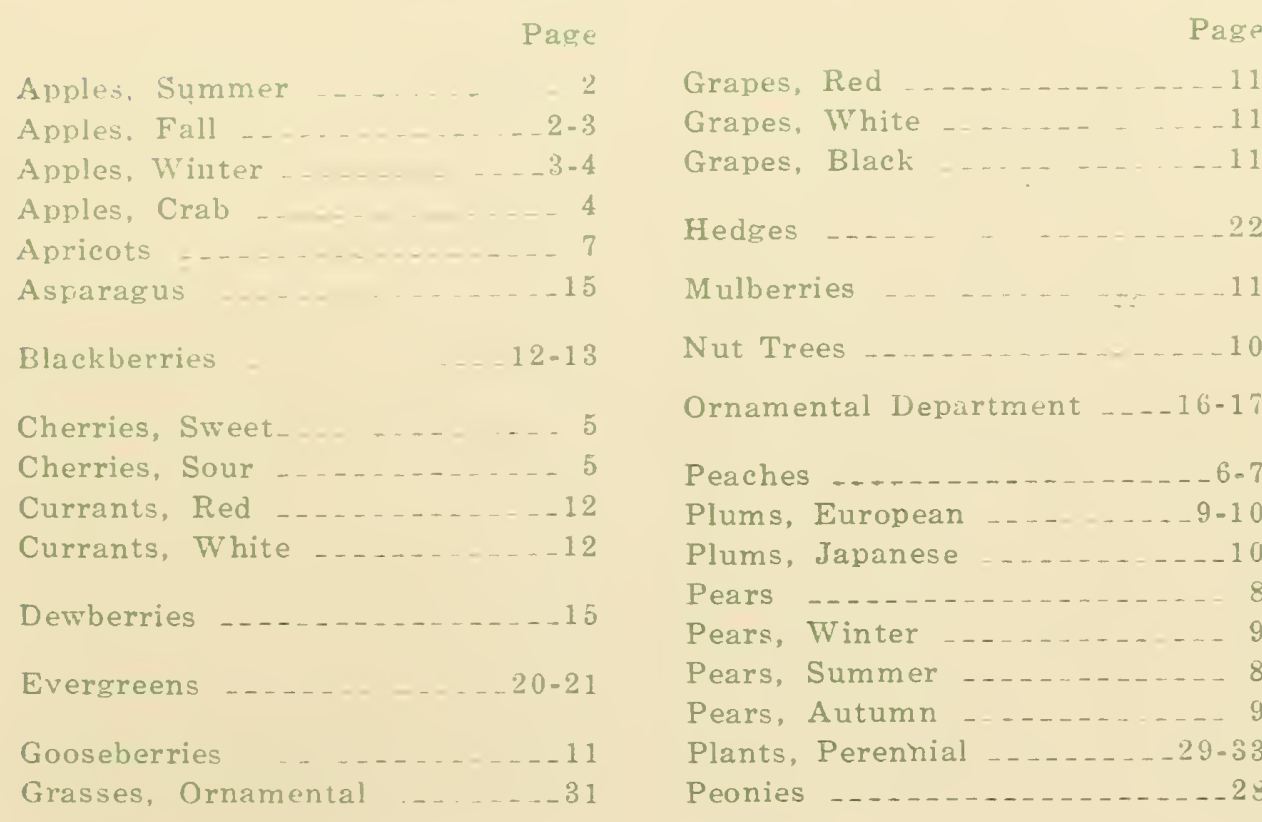

Quinces

Hage

Rhubart - 15

Raspberries, Purple _... ... 13

Raspberries, Black 1 ;

Raspberries, Red _... ... 13.14

Raspberries, Yellow _ _...14

Roses, Hybrid Perpetual .. 26-27

Ruses, Hybrid Tea............27

Roses, Polyantha _.. _ _ _... 27

Roses, Climbing _... . -28

Shrubs, Deciduous $\quad-23.26$

Strawberries .......... 14-15

Strawberries, Everbearing _... 15

Trees, Deciduous f _....17-19

Trees, Weeping _. $\ldots \ldots 19-20$

Vines, Cilmbing $\ldots \ldots \ldots-\ldots 29$ 


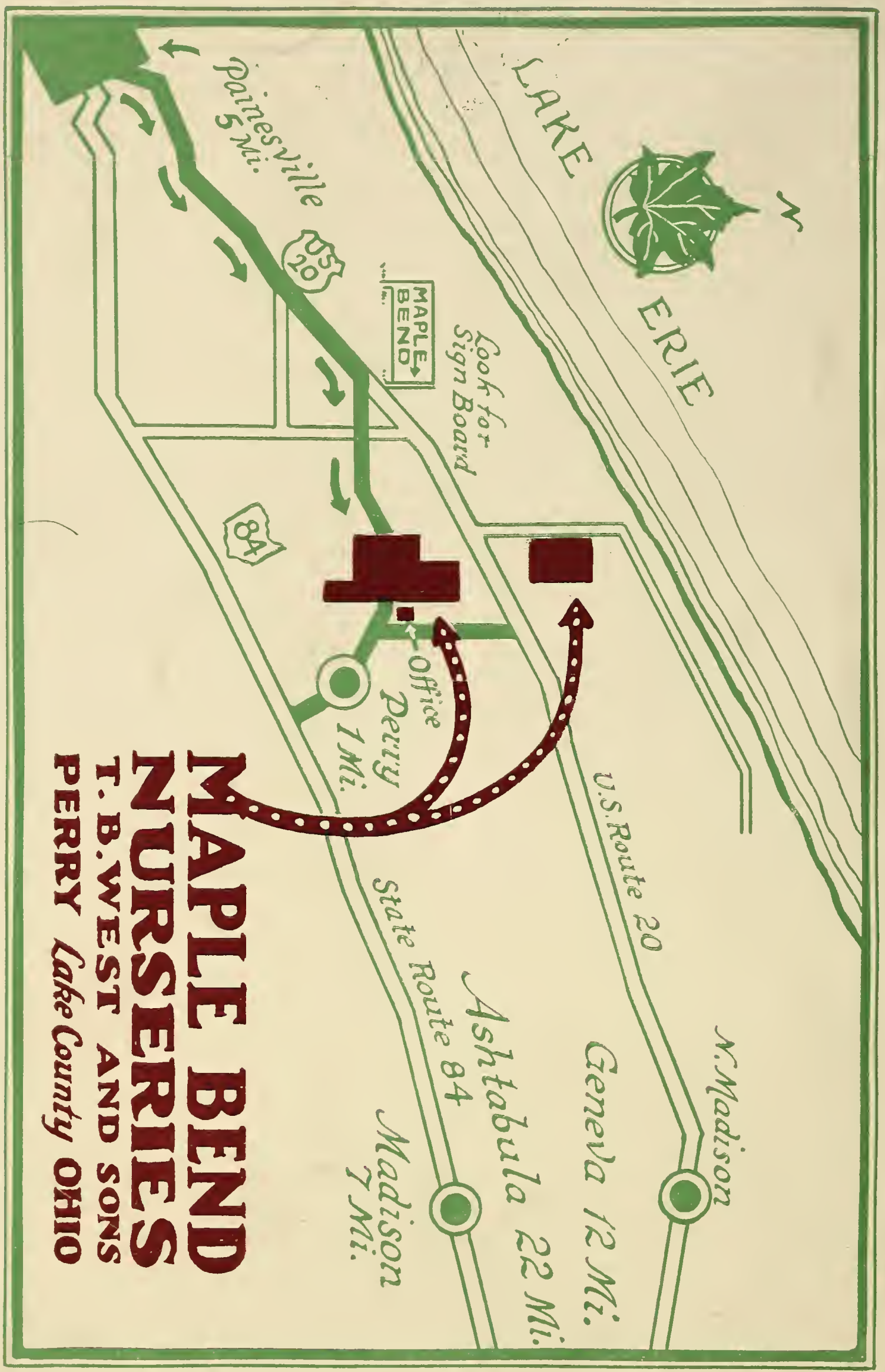

